JULI FERREIRA DE OLIVEIRA

A PRESENÇA DE PROFISSIONAIS INDÍGENAS NA ASSISTÊNCIA À SAÚDE NO BRASIL

DISTRITO FEDERAL (BRASÍLIA) 


\title{
A PRESENÇA DE PROFISSIONAIS INDÍGENAS NA ASSISTÊNCIA À SAÚDE NO BRASIL
}

\author{
Dissertação apresentada como \\ requisito parcial para a obtenção do \\ Título de Mestre em Saúde Coletiva \\ pelo Programa de Pós-Graduação \\ (Mestrado profissional) em Saúde \\ Coletiva da Universidade de Brasília.
}

Aprovada em 14 de fevereiro de 2017.

\author{
BANCA EXAMINADORA
}

Prof. Dra Magda Duarte dos Anjos Scherer (Presidente) Universidade de Brasília

\section{Prof. Dra Silvia Badim Marques}

Universidade de Brasília

Prof. Dr. Gersem José dos Santos Luciano - Baniwá Universidade Federal do Amazonas

Prof. Dra Tania Cristina Morais Santa Barbara Rehem (Suplente)

Universidade de Brasília UNIVERSIDADE DE BRASÍLIA 
FACULDADE DE CIÊNCIAS DA SAÚDE

PROGRAMA DE PÓS-GRADUAÇÃO EM SAÚDE COLETIVA

JULI FERREIRA DE OLIVEIRA

\title{
A PRESENÇA DE PROFISSIONAIS INDÍGENAS NA ASSISTÊNCIA À SAÚDE NO BRASIL
}

\begin{abstract}
Dissertação apresentada como requisito parcial para a obtenção do Título de Mestre em Saúde Coletiva pelo Programa de Pós-Graduação (Mestrado profissional) em Saúde Coletiva da Universidade de Brasília.
\end{abstract}

Orientadora: Magda Duarte dos Anjos Scherer

DISTRITO FEDERAL (BRASÍLIA) 
Dedico esta dissertação a todos (as) os (as) indígenas que estão ou estarão atuando como profissionais de saúde no Brasil. Que este trabalho seja instrumento de luta para os nossos povos para o alcance da educação e do trabalho como direito de cidadania. 


\section{AGRADECIMENTOS}

Agradeço primeiramente à Tupã, por ter me guiado, orientado e fortalecido para percorrer o caminho do estudo em prol da luta dos povos indígenas. Por ter me entregado resiliência e sabedoria para lidar com as adversidades e aprender com elas. Por isso, Tupã aé name asé oimoetê. Akgûab xe tuba, xe paiê, xe Tupã.

Aos meus pais, Antônio Pedro de Oliveira (in memoriam) e Jaci Ferreira de Oliveira, por terem sido usados por Tupã para me trazer ao mundo e por terem me entregado uma família linda e única, que me ensinou a cada dia o respeito, a bondade, o cuidado, a positividade e o amor aos nossos e aos outros.

À minha avó Judith Aristides de Oliveira (in memoriam), mulher guerreira que deixou muito de si em mim, me impulsionando a trilhar os caminhos com força e coragem. Com sua frase clássica "Tá ficando é bom" me mostrava nos pequenos detalhes do cotidiano, que mesmo diante de um contexto desfavorável ainda era possível lutar e reverter a situação, trazendo a maior força que já conheci em um ser humano, a energia da transformação, da luta e da fé.

À minha irmã Suzete Ferreira de Oliveira, que muito me encorajou durante toda a vida, me apoio nessa caminhada durante o mestrado e que me ensinou desde sempre o lado bom do ser humano, com sua sensibilidade e amor.

À minha família como um todo, que sempre acreditou em mim e me fortaleceu espiritualmente na minha jornada pela vida.

Ao meu esposo, Ewryky Apurinã, por ter me apoiado espiritualmente e por ter me ofertado tanto cuidado, compreensão e amor nos momentos que eu mais precisei ter resiliência e coragem no mestrado. Gratidão pelo respeito e pela força ancestral que têm aflorado em nós com a nossa união. As palavras não conseguiriam expressar o tamanho da minha gratidão e do meu amor por você. Akgûab, xe mena, xe taûsuba.

Ao meu povo Tupinambá de Salvador, capital da Bahia, por se levantar e reconstruir as suas histórias e memórias, aos poucos, no cotidiano da vida. Tenho fé de que o nosso povo voltará a se reconhecer e formará multidões, lutando juntos pelos nossos direitos. Esse tem sido um grande motivador na minha vida... a esperança da reconstrução e da restituição através dos tempos, por meio da ancestralidade Tupinambá! 
A todas minhas amigas e amigos, que me apoiaram de perto ou de longe. Gratidão especialmente a Alyne Melo, Tatiana Santos, Daniela Marques, Távilla Aparecida, Janaina Fernandes, Bruna Rocha e Maria Carmem Dantas, pela cumplicidade, irmandade e cuidado diário. Vocês tornaram meus dias mais bonitos e alegres. Mulheres fortes e sábias.

À Alyne Melo, por ter dividido seus dias comigo e ter me possibilitado trocar as dores e os amores sentidos no mestrado e na vida em Brasília. Pela sabedoria nos conselhos e pelo fortalecimento do nosso sagrado feminino.

À Tatiana Santos, amiga e chefa, irmã preta, que me fortaleceu muito na vida em Brasília. Gratidão pelas trocas, pelo seu extremo cuidado comigo nos momentos de cansaço e desânimo, pelo respeito e principalmente pelas trocas espirituais, que nos permitiram um fortalecimento mútuo na vida.

A Daniela Marques, mulher preta, irmã e parceira durante o mestrado em Saúde Coletiva. Gratidão pelo apoio, cuidado e parceria nesse tempo. Gratidão por ter sido a minha voz nos momentos de choro e por ter permitido que eu fosse a sua em outros. Por tanto ter me encorajado a expressar os meus pensamentos e ideias. Nossa presença juntas no mestrado fez toda a diferença na luta pelos nossos povos e em nosso fortalecimento na vida.

A Yonaré Barros, por ser luz em minha vida, por ter alegrado os meus dias e por ter reforçado sempre o meu potencial para cursar o mestrado. Gratidão pelas trocas e pelo cuidado.

À Liliane Bittencourt e Débora Santa Mônica, que me ensinaram o sentido de ser uma trabalhadora da saúde pública brasileira, e principalmente, me mostrando com suas próprias práticas a leitura crítica para o mundo e a luta contra as desigualdades raciais e sociais, tendo o trabalho como um meio de transformação da realidade. Reverência à vocês, mulheres fortes no mundo!

À Magda Duarte dos Anjos Scherer, por ter aceitado orientar o meu trabalho e por me permitir e se permitir aprender com as diferenças.

Aos povos indígenas, que foram a minha motivação para iniciar e finalizar esse estudo. "Esqueceram que éramos sementes e tentaram nos enterrar". Essa frase mostra um pouco da nossa força ancestral, que contrariando os desejos, planos e expectativas de muitos, crescemos em número, em sabedoria e força.

$E$ à todos que possuem importância na minha vida, porém que não foram citados nessas linhas escritas. 
"Eu creio que pelo Brasil inteiro, vai levantar, ou já levantou, índios esclarecidos, como eu, que levantará sua voz em prol da sua raça".

"Nós reclamamos a injustiça, a calúnia, a perseguição, a pobreza, a fome que a civilização nos trouxe".

"Minha vida, até o fim, vai ser essa luta insana, uma luta infrutífera até aqui".

(Marçal de Souza Tupã'i, liderança da etnia Guarani Nandeva, assassinado numa emboscada no ano de 1983 por lutar pelos direitos dos povos indígenas Documentário terra dos índios, 1979) 


\title{
RESUMO
}

\author{
Juli Ferreira de Oliveira ${ }^{1}$ \\ Magda Duarte dos Anjos Scherer ${ }^{2}$
}

O presente estudo objetivou analisar a presença de profissionais indígenas na assistência à saúde no Brasil. Para tanto, identificou o quantitativo de profissionais indígenas de nível superior atuantes na assistência à saúde, o quantitativo de indígenas matriculados em instituições de ensino superior (IES) e os pincipais nós críticos relacionados à Força de Trabalho (FT) Indígena da assistência à saúde no Brasil. Trata-se de uma pesquisa descritiva exploratória, de natureza aplicada, de abordagem quantitativa, realizada por meio de consulta à base de dados secundários, no período de janeiro de 2016 a janeiro de 2017. A população alvo do estudo foi profissionais indígenas de saúde de nível superior atuantes na assistência à saúde no Brasil em 2016, informados pela Plataforma Força de Trabalho em Sáude (PFTS), por meio do Cadastro Nacional de Estabelecimentos de Saúde (CNES), e os profissionais de saúde informados pelas três instituições filantrópicas que realizam a contratação de pessoal para atuar na saúde indígena, vinculadas à Secretaria Especial de Saúde Indígena (SESAI) do Ministério da Saúde (MS). Como resultados evidenciou-se: extrema iniquidade racial no mercado de trabalho da assistência à saúde no Brasil; lacuna importante no CNES, expressa pela quantidade significativa de não preenchimento do quesito raça/cor; inserção de indígenas desigual, desproporcional e inferior a inserção de brancos, negros e amarelos, quando comparado ao total de profissionais de nível superior informados pela PFTS/CNES, chegando a representar em proporção que os indígenas estão de 26 a quase 1500 vezes menos inseridos no mercado de trabalho em saúde do que indivíduos de outras raças; invisibilidade dos indígenas no campo teórico das produções de conhecimento, e no campo prático das ações de enfrentamento das desigualdades raciais no mercado de trabalho, como é o caso da lei de cotas em concursos públicos; presença de indígenas no ensino superior com tendência de expansão progressiva, porém ainda insuficiente; enfermagem e medicina incorporam o maior número de indígenas; maior número de profissionais indígenas presente nos estados de São Paulo, Rio de Janeiro, Paraná, Bahia e no Distrito Federal; e FT de nível superior atuante na assistência da saúde indígena formada majoritariamente por nãoindígenas, tendo menos de $10 \%$ dos (as) trabalhadores (as) indígenas. Conclui-se que é urgente a elaboração, revisão e execução de medidas de enfrentamento das desigualdades raciais no mercado de trabalho em saúde, tendo os indígenas como população-alvo. Bem como, medidas que visem ampliar o acesso e garantir a permanência de indígenas em IES e melhorar a qualidade da informação apresentada pelo CNES, com destaque para a necessidade de reversão da alteração que gerou a exclusão dos campos relacionados ao gênero e a raça/cor. O trabalho como direito social e como direito de cidadania ainda encontra entraves para se tornar realidade para muitos dos profissionais indígenas da saúde, apontando para a necessidade de políticas, ações, programas e projetos que visem garantir a igualdade de oportunidades, o combate ao racismo e a garantia do trabalho como direito social de todos (as) os (as) indígenas que desejem se inserir no mercado de trabalho em saúde.

Palavras-chave: Povos indígenas; iniquidade social; profissional de saúde; força de trabalho; Saúde indígena.

\footnotetext{
${ }^{1}$ Nutricionista pela Faculdade de Tecnologia e Ciências de Salvador - Ba. Especialista em Saúde da Família sob a forma de Residência Multiprofissional, pela Escola Baiana de Medicina e Sociedade Hólon. Especialista em Nutrição em Atenção Básica pela ENSP/FIOCRUZ. Mestranda em Saúde Coletiva pela UnB.

${ }^{2}$ Doutora em Enfermagem pela Universidade Federal de Santa Catarina. Professora do Departamento de Saúde Coletiva da Universidade de Brasília. Orientadora da presente pesquisa constituintes da dissertação do mestrado profissional do Programa de Pós Graduação em Saúde Coletiva da Universidade de Brasília.
} 


\begin{abstract}
Juli Ferreira de Oliveira ${ }^{1}$

Magda Duarte dos Anjos Scherer ${ }^{2}$

The present study aimed to analyze the presence of indigenous professionals in health care in Brazil. To that end, it identified the quantitative number of indigenous higher education professionals working in health care, the number of indigenous enrolled in higher education institutions (HEls), and the main critical nodes related to the Indigenous Health Workforce (FT) of health care in the Brazil. This is an exploratory descriptive exploration, of an applied nature, with a quantitative approach, carried out by consulting the secondary database, from January 2016 to January 2017. The target population of the study was indigenous health professionals of higher education who worked in health care in Brazil in 2016, informed by the Health Workforce Platform (PFTS), through the National Registry of Health Establishments (CNES), and the Health professionals informed by the three philanthropic institutions that contract the personnel to work in indigenous health, linked to the Special Secretariat of Indigenous Health (SESAI) of the Ministry of Health (MS). The results showed: extreme racial inequity in the labor market of health care in Brazil; Important gap in CNES, expressed by the significant amount of non-fulfillment of the race / color question; Insertion of indigenous people, disproportionate and inferior to the insertion of whites, blacks and yellows, when compared to the total of professionals of higher level informed by the PFTS / CNES, getting to represent in proportion that the natives are of 26 to almost 1500 times less inserted in the Health workforce than individuals of other races; Invisibility of indigenous people in the theoretical field of knowledge production, and in the practical field of actions to combat racial inequalities in the labor market, such as the quota law in public tenders; Presence of indigenous people in higher education with a gradual but still insufficient expansion; Nursing and medicine incorporate the largest number of indigenous people; The largest number of indigenous professionals present in the states of São Paulo, Rio de Janeiro, Paraná, Bahia and the Federal District; And higher-level FT active in indigenous health care, mostly non-indigenous, with less than $10 \%$ of indigenous workers. It is concluded that there is an urgent need to prepare, review and implement measures to combat racial inequalities in the health workforce, with indigenous populations as the target population. As well as, measures that aim to increase access and ensure the permanence of indigenous people in $\mathrm{HEI}$ and improve the quality of information presented by CNES, highlighting the need to reverse the change that generated the exclusion of the fields related to gender and race / color. Work as a social right and as a right to citizenship still finds obstacles to become reality for many of the indigenous health professionals, pointing to the need for policies, actions, programs and projects aimed at guaranteeing equal opportunities, combating racism and The guarantee of labor as a social right of all indigenous people who wish to enter the labor market in health.
\end{abstract}

Keywords: Indigenous peoples; Social inequity; healthcare professional; workforce; Indigenous health. 


\section{LISTA DE FIGURAS}

Figura 1 Força de Trabalho de nível superior empregada na assistência à saúde no Brasil, considerando as 14 profissões de saúde, 2016

Figura 2 Percentual de profissionais atuantes na assistência à saúde no Brasil que não declararam raça/cor no CNES, por categoria profissional, no ano de 2016 .....84 Figura 3 Proporção de profissionais na assistência à saúde do Brasil por raça/cor, 2016

Figura 4 Série histórica com quantitativo de indígenas matriculados em IES, de 2010 a 2015, no Brasil

Figura 5 Profissionais indígenas na assistência à saúde, desagregada por categoria profissional, 2016

Figura 6 Distribuição de profissionais indígenas de Enfermagem, Farmácia e Fisioterapia, desagregadas por região geográfica, 2016

Figura 7 Distribuição de profissionais indígenas de Psicologia, Serviço Social e Terapia Ocupacional, desagregadas por região geográfica, 2016 100

Figura 8 Distribuição de profissionais indígenas de Fonoaudiologia, Medicina e Odontologia, desagregadas por região geográfica, 2016 100

Figura 9 Presença de profissionais indígenas atuantes na assistência por Unidade da Federação, 2016 101

Figura 10 Profissionais componentes das 14 profissões de saúde atuantes na assistência à Saúde Indígena, em 2016 106

Figura 11 Força de Trabalho contratada pelo IMIP, SPDM e Missão Evangélica Caiuá para a Assistência à Saúde Indígena, segundo raça/cor, 2016. 108

Figura 12 Profissionais indígenas atuantes na Saúde Indígena por instituição contratante, no ano de 2016 109

Figura 13 Proporção de indígenas atuantes na assistência à "saúde indígena", desagregada por categoria profissional, em 2016 


\section{LISTA DE TABELAS}

Tabela 1 - Diferença na proporção de Indígenas na força de trabalho da assistência à saúde em relação a Brancos, Negros e Amarelos .90 Tabela 2 - Aspectos demográficos, de inserção acadêmica, caracterização étnica e identificação de conflitos nos estados com maior força de trabalho

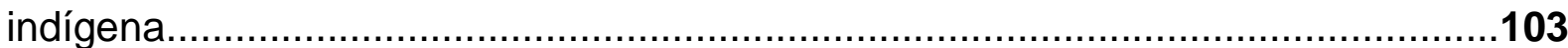




\section{LISTA DE QUADROS}

Quadro 1 - Variáveis e indicadores utilizadas para análise dos dados referentes à Força de Trabalho Indígena na Assistência à Saúde no Brasil. 81 


\section{LISTA DE ABREVIATURAS E SIGLAS}

ACS - Agente Comunitário de Saúde

AIS - Agente Indígena de Saúde

AISAN - Agente Indígena de Saneamento

ANTD-SUS - Agenda Nacional do Trabalho Decente para Trabalhadores e

Trabalhadoras do SUS

CADH - Convenção Americana de Direitos Humanos

CASAI - Casa de Apoio ao Índio

CERD - Comitê para a Eliminação da Discriminação Racial

CF - Constituição Federal

CIMI - Conselho Indigenista Missionário

CGSI - Coordenação Geral de Sistema de Informação

CNES - Cadastro Nacional de Estabelecimentos de Saúde

CNS - Cartão Nacional de Saúde

CNS - Conselho Nacional de Saúde

CNRM - Comissão Nacional de Médicos Residentes

COFEN - Conselho Federal de Enfermagem

CONEP - Comissão Nacional de Ética em Pesquisa

DCNT - Doença Crônica Não Transmissível

DEGERTS - Departamento de Gestão e da Regulação do Trabalho em Saúde

DSEI - Distrito Sanitário Especial Indígena

EMSI - Equipe Multidisciplinar de Saúde Indígena

ENSP - Escola Nacional de Saúde Pública

E-SIC - Sistema Eletrônico do Serviço de Informação ao Cidadão

FIOCRUZ - Fundação Oswaldo Cruz

FT - Força de Trabalho

FTS - Força de Trabalho em Saúde

FUNAI - Fundação Nacional do Índio

FUNASA - Fundação Nacional de Saúde

IBGE - Instituto Brasileiro de Geografia e Estatística

IDH - Corte Interamericana de Direitos Humanos

IES - Instituição de Ensino Superior 
IMIP - Instituto de Medicina Integral Professor Fernando Figueira

INEP - Instituto de Pesquisa Anísio Teixeira

IPEA - Instituto de Pesquisa Econômica Aplicada

MEC - Ministério da Educação

MNNP-SUS - Mesa Nacional de Negociação Permanente do SUS

MS - Ministério da Saúde

MS - Mato Grosso do Sul

MTE - Ministério do Trabalho e Emprego

NASF - Núcleo de Apoio à Saúde da Família

NASI - Núcleo de Apoio à Saúde Indígena

OIT - Organização Internacional do Trabalho

ONG - Organização Não-Governamental

ONU - Organização das Nações Unidas

PFTS - Plataforma Força de Trabalho em Saúde

$\mathrm{PL}$ - Projeto de Lei

PNASPI - Política Nacional de Atenção à Saúde dos Povos Indígenas

PROVAB - Programa de Valorização do Profissional da Atenção Básica

RAIS - Relação Anual de Informações Sociais

$\mathrm{RH}$ - Recursos Humanos

SAS - Secretaria de Atenção à Saúde

SESAI - Secretaria Especial de Saúde Indígena

SGTES - Secretaria da Gestão do Trabalho e da Educação na Saúde

SP - São Paulo

SPDM - Associação Paulista para o Desenvolvimento da Medicina

SPI - Serviço de Proteção aos Índios

SUS - Sistema Único de Saúde

TAC - Termo de Ajustamento de Conduta

TCLE - Termo de Consentimento Livre e Esclarecido

$\mathrm{TI}$ - Terra Indígena

TB - Tuberculose

UF - Unidade da Federação

UFRN - Universidade Federal do Rio Grande do Norte

UnB - Universidade de Brasília 


\section{SUMÁRIO}

APRESENTAÇÃO

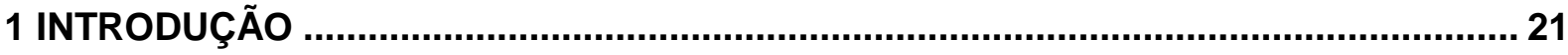

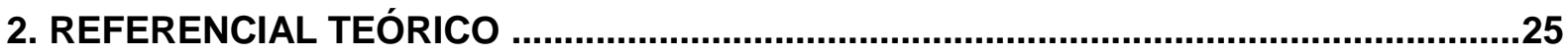

2.1 OS POVOS INDÍGENAS DO BRASIL: HISTÓRIA DE RESISTÊNCIA AO

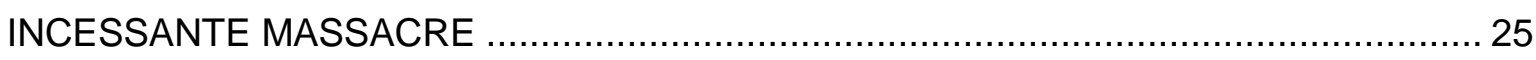

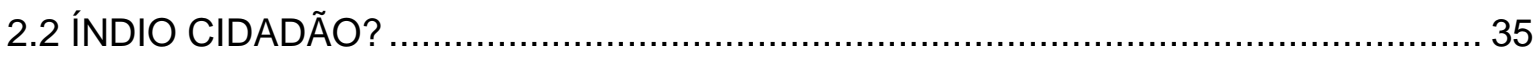

2.3 FORMAÇÃO DE INDÍGENAS NO ENSINO SUPERIOR ....................................... 46

2.4 FORÇA DE TRABALHO EM SAÚDE: ONDE SE ENCAIXAM OS INDÍGENAS? ....... 56

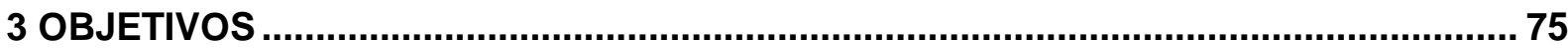

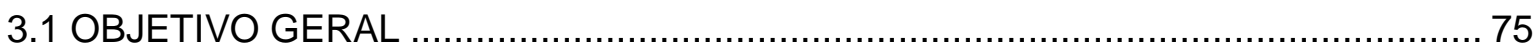

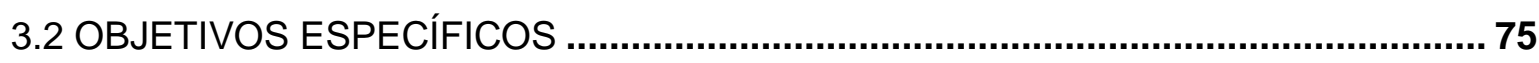

4 PERCURSO METODOLÓGICO

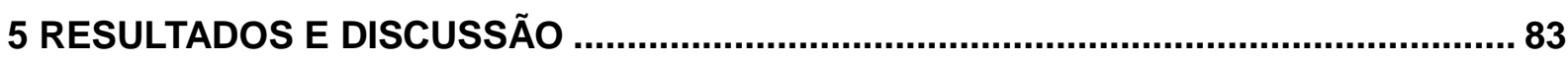

5.1 FORÇA DE TRABALHO DE NÍVEL SUPERIOR NA ASSISTÊNCIA À SAÚDE.......... 83

5.2 PROFISSIONAIS DE SAÚDE POR RAÇA/COR E A PRESENÇA DE INDÍGENAS NA

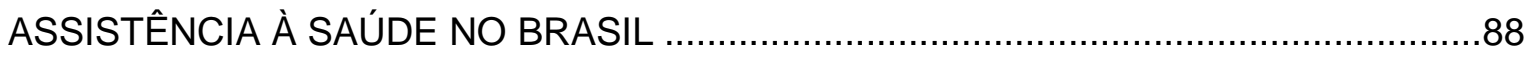

5.3 INDÍGENAS NO ENSINO SUPERIOR NO BRASIL ..........................................93

5.4 PROFISSIONAIS INDÍGENAS POR CATEGORIA PROFISSIONAL E LOCALIZAÇÃO

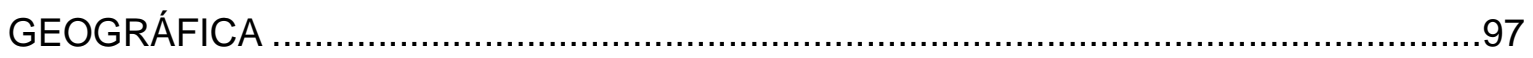

5.5 FORÇA DE TRABALHO INDÍGENA EMPREGADA NA SAÚDE INDÍGENA............. 105

5.6 PRINCIPAIS NÓS CRÍTICOS DA FORÇA DE TRABALHO INDÍGENA EM SAÚDE...111

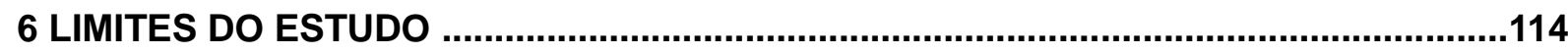

7 CONCLUSÕES E RECOMENDAÇÕES.............................................................118

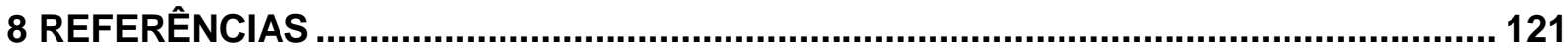

APÊNDICES

APÊNDICE A - Matriz de Sistematização da Revisão da Literatura

APÊNDICE B - Fluxograma orientador de busca em sítio eletrônico - Plataforma Força de Trabalho em Saúde

APÊNDICE C - Descrição do fluxograma orientador de busca em sítio eletrônico Plataforma Força de Trabalho Em Saúde

APÊNDICE D - Matriz de sistematização da Força de Trabalho em Saúde no Brasil APÊNDICE E - Matriz de sistematização da Força de Trabalho Indígena em Saúde por região e estado 
APÊNDICE F - Matriz de sistematização dos dados de saúde indígena SESAI/IMIP/SPDM/CAIUÁ - Atenção à Saúde

APÊNDICE G - Fluxograma orientador de busca em sítio eletrônico - Instituto de Pesquisa Anísio Teixeira (INEP)

APÊNDICE H - Descrição do fluxograma orientador de busca em sítio eletrônico Instituto de Pesquisa Anísio Teixeira (INEP)

ANEXOS..

142

ANEXO A - Parecer final do Comitê de Ética da Faculdade de Ciências da Saúde da UnB ANEXO B - Parecer de submissão de artigo na Revista Saúde e Sociedade 


\section{APRESENTAÇÃO}

Apresentar esse estudo exige bastante de mim, já que a motivação para desenvolvê-lo partiu da minha vivência como mulher indígena trabalhadora do Ministério da Saúde (MS), que trazia histórias bonitas e duras relacionadas ao ser indígena e profissional de saúde no Sistema Único de Saúde (SUS). Para tanto, precisarei rememorar alguns momentos que trarão maior clareza dos fatores que me impulsionaram a me aventurar no Mestrado Profissional em Saúde Coletiva na Universidade de Brasília (UnB), tendo como foco de trabalho a presença de profissionais indígenas na assistência à saúde no Brasil.

Sou indígena do povo Tupinambá, da capital da Bahia, Salvador. Para aqueles ditos "entendedores" dos povos indígenas surgiria com certeza um questionamento inicial... Tupinambá em Salvador? Na cidade? E respondendo já adianto: Sim, nasci na cidade e vivi lá. Salvador sempre foi território ancestral do povo Tupinambá e palco de um lamentável massacre. Não experenciei a vida numa aldeia, mas vivi a vida na favela, como muitos outros indígenas que nem possuem a consciência de suas raízes ancestrais, mas que estão lá e que possuem no seu modo de vida a essência cultural que the distingue de outros grupos. No meu caso, as histórias e ensinamentos sobre meu povo foram passadas pela minha avó paterna, única da família a retomar nossa raiz indígena, sem muito ressoar nos jovens. Fui me entender indígena e buscar as histórias contadas pela minha avó Judith depois da vida adulta, quando conheci indígenas do povo Pataxó e reconheci neles o meu modo de viver e de ver a vida, o mundo. A partir daí o mundo se abriu, com o agravante de que meus passos já não eram mais acompanhados fisicamente pela única pessoa que me trazia as memórias e ensinamentos. Trago em mim a história de uma família que venceu a fome e a extrema pobreza financeira, a falta de direitos e em muitos momentos a própria falta da cidadania. Momentos longos adversos que me fizeram crescer e desenvolver a busca por justiça e por um mundo melhor. Entender minhas raízes ancestrais e me apropriar cada vez mais do conhecimento valoroso que eu detinha foi um caminho para meu empoderamento no mundo.

Me aventurei na universidade pela primeira vez quando cursei o curso de Nutrição, na cidade do Salvador. Fui selecionada no programa Faz universitário por 
conta da nota do Exame Nacional do Ensino Médio. Logo após minha formação, no ano de 2009, me inseri na docência, como supervisora de estágio em Nutrição na Saúde Pública, trilhando a partir daí um caminho rico como Nutricionista do SUS. No ano de 2014, comecei a trabalhar no MS com o objeto da negociação coletiva e Gestão do Trabalho no SUS. Iniciei com muitas expectativas de colaborar para o enfrentamento das desigualdades raciais entre os trabalhadores indígenas da saúde. Qual foi a minha surpresa? Perceber que em nenhum dos espaços de diálogo em que passei, mesmo estes envolvendo gestores e trabalhadores do SUS, se considerava que existiam indígenas atuando como profissionais de saúde de nível superior. E no momento em que eu pontuava que as iniquidades não envolviam apenas negros e brancos, logo surgiam as "pérolas": "mas não estamos falando de usuários...estamos falando de profissionais de saúde" ou então "mas não temos estudos que comprovem que existem indígenas atuando na assistência à saúde". Essa negação que envolve os indígenas ocuparem outros lugares sociais diferentes do lugar folclórico em que a sociedade brasileira os colocou me chocou.

Realmente é tão absurdo pensar num indígena atuando como profissional de saúde? E a cada momento eu percebia mais claramente as faces variadas do racismo. Nesses momentos acabava por compartilhar as diversas situações de intolerância, preconceito e discriminação que já sofri atuando como profissional do SUS, como por exemplo quando nos dias de atendimento clínico o (a) usuário (a) entrava no meu consultório e perguntava: "uma índia nutricionista?" Ou "a doutora é uma índia?" com espanto tão absurdo que me constrangia. Com o tempo passei a reagir com serenidade a essas manifestações vindas dos não-indígenas. Vale a ressalva de que eu não trabalhava com a saúde indígena e sim com a saúde de não-indígenas, o que aumentava ainda mais os choques e estranhamentos. $O$ fato é que esses encontros e desencontros no SUS e no MS me mostraram a importância de produzir conhecimento sobre os trabalhadores indígenas de saúde, buscando assim elementos que fundamentassem os debates, como exigiam os não-indígenas.

Mal sabia eu os desafios que a universidade me reservava. Após aprovação em processo seletivo me deparei no Curso de Mestrado Profissional em Saúde Coletiva da UnB, com a maioria absoluta de mestrandos brancos (na minha turma, no primeiro semestre só existia eu de indígena e duas alunas negras, todos os outros (as) eram brancos (as) e de classe social privilegiada). O curso não dispunha de vagas específicas para indígenas e negros, o que explicava a cor do curso. 
Os estranhamentos foram diversos e em mais um espaço de poder e saber a negação das discussões que cercam as discriminações raciais e a não cidadania dos povos indígenas e do povo negro se tornava presente. A produção dessa dissertação foi regada por experiências profundas e dolorosas, que tornavam o ambiente da universidade, especificamente no mestrado, inóspito para mim. Conviver cotidianamente com o racismo e a ridicularização entre os colegas e professoras era massacrante. Situações que envolveram: docente comparando, em sala de aula, as práticas tradicionais de cura realizada por curandeiros ao charlatanismo; outros, por ensinarem muito bem o que aprenderam, reconhecendo unicamente a ciência do branco como verdade absoluta e desvalorizando todas as outras formas de ciência; colegas de mestrado que ao entrar em sala de aula me pediam (em voz alta) para fazer a dança da chuva; docentes me infantilizando ou me tratando como se eu não estivesse entendendo a linguagem falada por eles, enfim, situações diversas que incluíram mais peso à minha formação e consequentemente à elaboração dessa dissertação.

Meu maior pesar nesse processo foi desenvolver o referencial teórico e rever toda a história de massacre, dominação e dizimação tão naturalizada nas falas da academia. O pior é ver que o branco matou, feriu, roubou, exterminou povos inteiros e ainda escreveu tudo, de tão normal e legal que era e ainda é, de tão autorizados que eram e ainda são. Depois percebi que os indígenas começavam a se apresentar no meio científico, com escritas e pensamentos próprios, que muito diziam do meu próprio pensamento. Percebi a duras penas que o exercício do enfrentamento é pesado, mas necessário. E que a universidade precisa cada vez mais receber a favela, a aldeia, os quilombos para fazer os contrapontos reais, de acordo com a vida que levam e com a diversidade de visões de mundo.

Dessa forma, essa dissertação é a minha forma de gritar ao mundo acadêmico, científico e do trabalho que os povos indígenas são vítimas de constantes desrespeitos, discriminações e negações de direitos. Não é fácil no Brasil para o indígena nem se manter vivo, imagine só cursar uma graduação e se tornar profissional de saúde! Não, as chances não são iguais! O poder soberano do Estado continua decidindo quem deve morrer ou viver. O que mudou nisso tudo durante os tempos? Nós! Nós mudamos! Nossas armas são outras e reforçaremos nossos guerreiros e guerreiras com o pensamento crítico sobre as estratégias que utilizaram contra nós e que hoje, podem apoiar nossa reação, nossa resistência. 
Então, finalizo trazendo essa dissertação como oferta à todos os parentes indígenas que estão nesse campo de discussão, disputa e luta por melhores condições de vida e pela ampliação da nossa participação em todos os ramos da sociedade, como é o caso do trabalho. Espero que esse trabalho traga elementos para que as discussões sobre a gestão do trabalho e sobre o enfrentamento das disparidades raciais no mercado de trabalho em saúde possam se ampliar e considerar os indígenas como profissionais de saúde alvo de todas essas desigualdades e disparidades e protagonistas de suas vidas.

Força para lutar e sabedoria para se manter em equilíbrio espiritual e físico é o que desejo para todos (as) que se propuserem à essa luta. 


\section{INTRODUÇÃO}

Abordar a presença de profissionais indígenas na assistência à saúde no Brasil exige minimamente uma tentativa de leitura ampliada e contextualizada do ponto de vista sócio histórico. Isto remete automaticamente a interligação que existe entre as dimensões do trabalho e da educação com a condição real de cidadania ou não-cidadania vivenciada pelos povos indígenas nesse país. Logo, a aposta deste estudo é traçar um fio condutor de pensamento, que permita a conexão imediata entre o direito ao trabalho e a educação com as condições de vida dos povos indígenas que por si só denunciam a cidadania ou a falta dela, o que inclui a dificuldade de acessar a formação no ensino superior e o mercado de trabalho em saúde.

O trabalho faz parte do conjunto de aspectos que compõem os direitos sociais, que constituem a cidadania, juntamente com os direitos políticos e civis (LAVALLE, 2003; CARVALHO, 2002). Assim, a garantia teórica da cidadania deveria ao menos garantir condições mínimas de vida digna aos cidadãos, como o acesso à educação de qualidade e ao mercado de trabalho, como apontado por Carvalho (2002), o que não se concretizou na prática para os povos indígenas brasileiros, que historicamente foram alvo de opressão e dizimação, ficando com isso marginalizados do acesso à bens e serviços, como é exemplo claro o campo do trabalho, o que inclui o trabalho em saúde.

Coimbra Jr. (2014) denuncia o significativo atraso no campo dos direitos sociais dos povos indígenas do Brasil, apontando como causa o complexo processo histórico, que combinou eventos como os conflitos fundiários envolvendo indígenas e não-indígenas, a degradação ambiental que alterou o modo de vida dos povos indígenas, chegando à evidenciação da omissão do Estado, que precipitou importantes desigualdades sociais contra os povos indígenas nas áreas da saúde, educação, habitação, dentre outras. $\mathrm{O}$ autor evidencia que a fronteira brasileira que diferencia e separa indígenas e não-indígenas é marcada justamente por essas e outras desigualdades sociais, que colocam os indígenas em posição de desvantagem social clara.

Diante desse quadro que evidencia a exclusão e questiona os direitos de 
cidadania para os povos indígenas brasileiros, Gersem Baniwá (LUCIANO, 2009), aponta a emergência do protagonismo indígena, principalmente durante o processo de redemocratização do país, em direção à conquista de direitos sociais, entre eles principalmente os relacionados à saúde e educação, com destaque para a formação universitária, o que abre caminhos claros para a conquista real da cidadania, através do acesso às universidades e posteriormente ao mercado de trabalho. $O$ autor afirma ainda que os povos indígenas passaram a se aproximar da vida nacional, visando ampliar os espaços de participação, diálogo e negociação, aumentando a capacidade de fazer alianças e interferir nas decisões que os envolvem. Dessa forma, fica nítido que discutir a presença do (a) trabalhador (a) indígena na saúde é também questionar o real direito de cidadania, já que o trabalho e a educação são direitos sociais que a constituem. É fundamental compreender os diversos sentidos que o trabalho possui para o ser humano, bem como as especificidades que cercam os povos indígenas e o campo do trabalho em saúde.

Segundo Marx (1984), o trabalho nada mais é do que um produto fruto de uma relação de venda da força de trabalho por parte do (a) trabalhador (a) ao capitalista, detentor dos meios de produção e do capital. Lhuilier (2013), aponta o trabalho num duplo sentido, se fundando a partir da relação entre o homem e a natureza, mas também enquanto suporte para as relações sociais, já que se constitui como vetor da coesão das relações sociais, da identidade e da realização do (a) trabalhador (a). No campo da saúde, várias nomenclaturas são utilizadas como força de trabalho em saúde (FTS), recursos humanos $(\mathrm{RH})$, pessoal de saúde, categorias profissionais, trabalhadores da saúde, dentre outros.

Paim (1994), propõe uma superação dos conceitos utiilizados para caracterizar tanto a Força de Trabalho (FT) quanto os $\mathrm{RH}$, apontando para a necessidade da criação de um conceito mais amplo que se adeque à complexidade do setor saúde. Para tanto, propõe o conceito de Força de Trabalho em Saúde, onde o (a) trabalhador (a) é compreendido (a) como agente protagonista e sujeito de transformações sociais por meio do trabalho, ou como o próprio autor nomeia, "sujeito-agente das práticas de saúde, eticamente comprometido com a vida e com a redução do sofrimento humano" (PAIM, 1994. p.64).

Assim, conectando as discussões que envolvem a cidadania, com foco no trabalho como direito social, a condição de exclusão e desigualdade social vivida pelos povos indígenas no Brasil, os conceitos de FTS, com as disparidades de 
gênero e raça que compõem o mercado de trabalho como apontado por Abramo (2006), evidencia-se a complexidade que envolve tal discussão. Laís Abramo (2006) reforça a desigualdade de gênero e raça como eixo estruturante da matriz da desigualdade social no Brasil, auxiliando na reprodução e manutenção das situações de exclusão social. E, em se tratando de exclusão social e mercado de trabalho, torna-se pertinente analisar a situação dos indígenas brasileiros, que pouco aparecem nas estatísticas dos trabalhadores em saúde e muito menos nos referenciais teóricos que abordam as desigualdades de gênero e raça no trabalho.

É curioso como diversos estudiosos pautam as desigualdades de raça no trabalho, restringindo as análises aos brancos e negros - indicando diferenciais no quantitativo de brancos e negros no mercado de trabalho, de remuneração, de jornada de trabalho, de exposição a situações de violência, etc. (ABRAMO, 2006; TOMEI, 2005, BRASIL, 2004). O intrigante é perceber que os povos indígenas estão invisibilizados tanto na memória dos pesquisadores dessa temática quanto nas produções institucionais que se propõem a gerar informações para a formulação de políticas de combate as discrimações raciais no trabalho. Será que o Brasil não tem indígenas inseridos no mercado de trabalho? Ou será que a invisibilidade já se constitui no preconceito e racismo empregados contra os povos indígenas?

Segundo Lima (2007) ainda falta muito para que os brasileiros descubram que não amam e nem admiram os ancestrais indígenas desse território. Reforça ainda que no imaginário popular existem ideias equivocadas sobre os povos indígenas, o que gera diferentes reações que vão desde a simpatia imediata até as violências diversas. Destaca com isso que muitas vezes a simpatia é tão perigosa quanto a agressão aberta empregada. Por essa ótica, a simpatia (reproduzida pela infantilização do indígena) subestima, discrimina e inferioriza tanto quanto a agressão aberta o faz.

Segundo Laís Abramo (2006), os aspectos que cercam as desigualdades de gênero e raça no campo do trabalho devem compor análises específicas, devendo ser consideradas nos processos de formulação de políticas públicas em geral. Nesse contexto, vale a preocupação com a invisibilidade dos indígenas nas discussões sobre as desigualdades raciais no mercado de trabalho, bem como sua invisibilidade nos levantamentos sobre a força de trabalho em saúde no Brasil.

Soma-se a este panorama o desenvolvimento de medidas de ações afirmativas para a ampliação do acesso dos povos indígenas na área da educação 
(DAVID, MELO, MALHEIRO, 2013; AMARAL, BAIBICH-FARIA, 2012; GARLET, GUIMARÃES, BELLINI, 2010, LIMA, 2012), porém que se mantém inexistentes no campo do trabalho, o que inclui consequentemente a falta de medidas de ações afirmativas para captação de indígenas no mercado de trabalho em saúde, mesmo existindo estímulo para a ampliação da formação de profissionais indígenas de saúde.

Essa situação poderá gerar, se não já gerou, descompasso entre a formação e a captação de indígenas pelo mercado de trabalho em saúde, como por exemplo, pela assistência à saúde como área importante na oferta de postos de trabalho na saúde, especificamente no SUS, maior empregador no campo da saúde (KOSTER E MACHADO, 2012).

Considerando todos esses elementos apontados como fios condutores da reflexão sobre a presença dos indígenas na assistência à saúde no Brasil, destacam-se três fatores que justificam o estudo, bem como sua relevância no campo das políticas, programas e ações de gestão do trabalho em saúde: 1 - a ausência de estudos que tracem o panorama da força de trabalho indígena no campo da saúde; 2 - a necessidade de produção de dados sobre as populações indígenas no Brasil; e, 3 - a necessidade de realizar a gestão do trabalho dos indígenas que estão no mercado de trabalho em saúde, tendo como foco principal o combate ao racismo e a discrimação, a saúde do trabalhador e da trabalhadora indígena da saúde e a preservação da diversidade cultural trazida por esses profissionais de saúde.

Vale destacar que esse estudo tem potencial para auxiliar na produção de conhecimento científico tanto sobre os povos indígenas no ensino superior e no mercado de trabalho em saúde quanto sobre a cidadania desses povos, temáticas que se interligam diretamente, porém que são pouco problematizadas de forma integrada. Assim, pode servir de base para discussões, articulações políticas e recomendação de medidas de combate às iniquidades raciais no mercado de trabalho em saúde, bem como para o rompimento da invisibilidade dos indígenas no mercado de trabalho, nos referenciais teóricos e nas políticas que tratam desse campo no âmbito da saúde.

Reconhecendo a integração dessas temáticas, o referencial teórico foi estruturado em quatro capítulos: capítulo 1 - Os povos indígenas do Brasil: história de resistência ao incessante massacre; capítulo 2 - Índio cidadão?; capítulo 3 - 
Formação de indígenas no ensino superior; e capítulo 4 - Força de Trabalho em Saúde: onde se encaixam os indígenas?

\section{REFERENCIAL TEÓRICO}

Os capítulos constituintes do referencial teórico foram construídos utilizando conceitos e referenciais não-indígenas, provenientes do saber ocidental e disponíveis nas bases de dados científicas, já que a universidade possui exigências específicas sobre o tipo de referência aceita para tais produções. Porém, buscou-se inserir e referenciar autores indígenas que abordam o tema, que apesar de escassos na atualidade somam ao debate o olhar indígena, bem como elementos essenciais para a construção crítica de possíveis caminhos relacionadas ao campo da educação e trabalho dos povos indígenas brasileiros.

\subsection{OS POVOS INDÍGENAS DO BRASIL: HISTÓRIA DE RESISTÊNCIA AO INCESSANTE MASSACRE}

O Brasil no século XVI, período em que ocorreu a sua invasão, apresentava por volta de 5 milhões de indígenas, o que para melhor entendimento pode ser comparado com a população total da Europa na época, de acordo com dados da Fundação Nacional de Saúde (Funasa) (BRASIL, 2002). Na região litorânea do Brasil, segundo estimativas da Fundação Nacional do Índio (Funai) existiam 2 milhões de indígenas vivendo por toda extensão litorânea no ano de 1500. A magnitude do massacre promovido pelos brancos europeus fica evidenciada ao considerar que após 70 anos de invasão e dominação houve o extermínio de $90 \%$ dos povos indígenas do litoral, restando apenas 200 mil indígenas (BRASIL, 2016).

Considera-se como grandes motivadores de tal barbárie, a ganância e a ambição, como forma cultural de expansão econômica (CUNHA, 2012). Prado Jr. (1994), apontou na literatura a colonização dos trópicos como a representação de uma empresa comercial, no plano mundial internacional, destinada a extrair benefícios para o comercio europeu, por meio da exploração de recursos naturais de 
territórios inexplorados (PRADO JR, 1994).

Nesse impulso por enriquecimento foram impostas aos povos originários a colonização e a cristianização compulsória. Esses dois movimentos, paralelos e complementares, propiciaram mudanças no modo de vida dos povos indígenas, trouxeram epidemias de doenças infecciosas que culminaram na morte de milhares, impuseram a escravidão, o trabalho forçado, os maus tratos e a sedentarização compulsória em aldeamentos e internatos. Bem como diversas punições voltadas à extinção das manifestações religiosas e dos movimentos de resistência, gerando desestruturação social, econômica e dos valores coletivos dos povos indígenas. (BRASIL, 2002; CUNHA, 2012).

Bernardes (2011) chama atenção para o fato da colonização ter sido balizada sob a lógica e estrutura do racismo, muito ancorada nas noções de tecnologias de poder apontadas por Michel Foucault. Para Foucault o racismo se desenvolve primo com a colonização, e consequentemente com o genocídio colonizador. Diz ainda que:

\begin{abstract}
O racismo é indispensável como condição para poder tirar a vida de alguém, para poder tirar a vida dos outros. A função assassina do Estado só pode ser assegurada, desde que o Estado funcione no modo do biopoder, pelo racismo [...] É claro, por tirar a vida não entendo simplesmente o assassinato direto, mas também tudo o que pode ser assassínio indireto: o fato de expor à morte, de multiplicar para alguns o risco de morte ou, pura e simplesmente, a morte política, a expulsão, a rejeição, etc. (FOUCAULT, 2005, p. 306).
\end{abstract}

Esses apontamentos de Foucault, no ano de 1976 denunciaram as estruturas racistas de poder já postas pelo Estado na época e anunciaram o porvir, ou seja, a perpetuação do problema. Reforça a trama que evidencia que:

O racismo é ligado ao funcionamento de um Estado que é obrigado a utilizar a raça, a eliminação das raças e a purificação da raça para exercer seu poder soberano. A justaposição, ou melhor, o funcionamento, através do biopoder, do velho poder soberano do direito de morte implica o funcionamento, a introdução e a ativação do racismo (FOUCAULT, 2005. p. 309).

Bernardes (2011) aponta que a ação do Estado baseada no racismo evidencia uma "racionalidade colonizadora", utilizando-se de estratégias que vão desde práticas disciplinares até àquelas baseadas na biopolítica, de controle das massas, da população. Evidencia ainda que a partir das estratégias disciplinares é que se constituem, no Brasil, as políticas públicas voltadas para os povos indígenas, 
enquanto ação do Estado, que ao invés de equalizar direitos, acaba criando e aumentando as diferenças de acesso aos direitos e aos suportes sociais.

Tanto Foucault quanto Bernardes evidenciam de forma clara o poder do Estado em deixar morrer, tirando as oportunidades e os direitos de alguns grupos, baseado em noções evolucionistas onde uma raça seria mais "evoluída" ou "superior" e portanto teria o direito soberano sobre a vida e a morte das outras, entendidas por eles como menos desenvolvidas ou "menos humanas". Essas noções se cristalizaram socialmente e determinam as formas de ação desenvolvidas pelo Estado, principalmente porque a elite dominadora sempre concentrou e ainda hoje concentra os meios de produção e o capital, estando em posição de poder privilegiada com relação a outros grupos étnicos, como é o caso dos povos indígenas.

No caso brasileiro, considerando os povos indígenas como povos originários do território, que ao longo da história vem sendo entendidos pelo Estado como atraso para o "progresso" e "desenvolvimento" do país, percebe-se estratégias racistas do Estado brasileiro voltadas para deixar morrer os indígenas, sua cultura, suas especificidades, suas forma de organização e de interação sócio-política. impulsionando e muitas vezes financiando o genocídio dos povos indígenas, em nome do desenvolvimento econômico representado pelo agronegócio, que além de matar os povos originários e destruir seu modo tradicional de viver ainda termina por destruir o meio ambiente e diversas formas de vida.

O Brasil, de acordo com o Censo demográfico de 2010, realizado pelo Instituto Brasileiro de Geografia e Estatística (IBGE, 2012), possui 896,9 mil indígenas. Destes, 817,9 mil pessoas autodeclaradas como indígenas no quesito cor ou raça, acrescido de 78,9 mil pessoas residentes em terras indígenas, porém que não se declararam indígenas no quesito cor ou raça, mas que se consideraram indígenas de acordo com as tradições, costumes, cultura, antepassados, etc.

Os povos indígenas apresentam configurações particulares de costumes, crenças e língua, de formas de inserção com o meio ambiente, de história de interação com os colonizadores e de relação com o Estado nacional brasileiro [...] O reconhecimento étnico se pauta na conjugação de critérios definidos pela consciência da identidade indígena e de pertencimento a um grupo diferenciado dos demais segmentos populacionais brasileiros e pelo reconhecimento por parte dos membros do próprio grupo (IBGE, 2012. p.6).

Do total de quase 900 mil indígenas em território brasileiro, 63,8\% residem em 
terras indígenas e $36,2 \%$ em cidades. Totalizam 305 povos, que falam 274 línguas diferentes. Esse quantitativo é alarmante quando consideramos que existiam mais de 5 milhões de indígenas, distribuídos em aproximadamente 970 etnias, no período em que ocorreu a invasão do Brasil pelos portugueses (BRASIL, 2016), o que representa o extermínio da maior parte da população e a extinção de etnias inteiras pela elite branca que fundou o Estado-nação no Brasil.

Simoni e Dagnino (2016) chamam atenção para o intenso crescimento das populações indígenas nas áreas urbanas, representando entre 1991 e 2000 um aumento de $440 \%$ e queda de $18 \%$ na década seguinte, o que pode ser explicado pela introdução da questão da etnia pelo IBGE, gerando possível inibição da resposta do campo "indígena". Os autores chamam atenção para a situação de vulnerabilidade social dos indígenas nas cidades, uma vez que são vítimas da exclusão no acesso aos serviços específicos de saúde e educação e à assistência da Funai.

A dispersão dos indígenas brasileiros é evidenciado pelo Censo demográfico ao apontar que $80,5 \%$ dos municípios brasileiros possuem pelo menos um indígena autodeclarado residindo. Esse processo foi bastante intenso na região nordeste, devido ao movimento de etnogênese que se dá em diversas regiões do Brasil (IBGE, 2012). A etnogênese é caracterizada por Luciano (2006. P. 112), como "fenômeno em que, diante de determinadas circunstâncias históricas, um povo étnico, que havia deixado de assumir sua identidade étnica por razões também históricas, consegue reassumi-la e reafirmá-la, recuperando aspectos relevantes de sua cultura tradicional".

A distribuição espacial dos indígenas autodeclarados revelou que a região norte e a Amazônia mantêm a maior parte dos indígenas com 37,4\% dos autodeclarados. Notou-se redução de indígenas nas regiões sudeste e sul, com destaque para a primeira, o que pode ser atribuído provavelmente à migração, fenômeno este ainda pouco explorado na literatura científica. Já considerando as Unidades da Federação (UF), o Amazonas possui a maior população indígena autodeclarada do Brasil, com 168,7 mil pessoas, seguida por Mato Grosso do Sul (MS) com 73.295 mil e a Bahia com 56.381 mil indígenas autodeclarados (IBGE, 2012).

Ressalva deve ser dada à presença dos indígenas no Estado de São Paulo (SP), 7a UF com maior número absoluto de indígenas, 41.794 mil, superando 
estados localizados no bioma amazônico como, por exemplo, o Pará e parte do Maranhão (IBGE 2012). Diante dos fatos cabem às seguintes reflexões: Será que a presença significativa de indígenas em São Paulo, para além da existência de povos originários desse território, também poderia estar ligada à busca por qualificação profissional e inserção no mercado de trabalho, caracterizando assim uma possível migração?

Segundo Pagliaro, Azevedo e Santos (2005), as diferentes dimensões que constituem a dinâmica demográfica dos povos indígenas ainda é pouco conhecida, onde se inclui o fenômeno das migrações de um território para outro. Os autores ressaltam que a carência de estatísticas contínuas sobre os povos indígenas é um fator preocupante, já que possuem potencial para orientar projetos econômicos, educacionais e de assistência médica, a realização de projeções de futuros problemas, o que possibilitaria ações de ordem preventiva. Diante disso, que o Censo populacional de 2010 ganhou centralidade no que se refere à demografia dos povos indígenas.

Pagliaro, Azevedo e Santos (2005) frisam que, para além da falta de interesse da comunidade de demógrafos do Brasil em produzir conhecimento sobre os povos indígenas, os Antropólogos, tradicionalmente implicados e inseridos nas temáticas indígenas, produzem dados qualitativos importantes sobre nascimento, estágio e ciclo da vida, morte, regras de casamento e mobilidade, entre outros, inserindo-os rotineiramente em etnografias, porém, sem abordar a dimensão quantitativa, por falta de aproximação com esse método de pesquisa e produção de conhecimento.

Neste contexto de escassez de informações e pouco conhecimento aprofundado sobre os povos indígenas existe um ponto crítico muito conhecido por todos e que se mostra determinante das condições de vida e saúde das 305 etnias indígenas conhecidas no Brasil, que é a terra e os territórios ancestrais, alvo de interesses econômicos e disputas. A luta dos povos indígenas pela garantia de suas terras e territórios ancestrais junto ao governo brasileiro se mostra contínua e intensa ao longo dos anos, tendo como resultado visível as 678 terras indígenas (TI) existentes em quase todos os estados da federação, somando uma área total de 112.703.122 hectares. A maioria das TI estão localizadas na região da Amazônia legal (414), representando o total de 110.970 .489 hectares, ocupando assim $21,73 \%$ dessa região e 13,1\% de todo território nacional (LIMA, 2012).

Lima (2012. p. 171) chama atenção para a riqueza de recursos naturais 
presentes nas terras indígenas, representada por grande biodiversidade e recursos minerais. As terras indígenas estão entre as poucas áreas preservadas, considerando o Brasil um território violentamente "devastado pelo extrativismo selvagem, pela exploração mineral, pelo desmatamento e/ou queimada de florestas para produção de carvão, para abertura de pastos para criação de gado, para a cana e a soja do agronegócio".

Nesse pequeno parágrafo supracitado, já se pode vislumbrar interesses divergentes e ações que se põem antagônicas no sentido de preservar ou destruir o meio ambiente. Lima (2012), denuncia que muitas TI estão atualmente invadidas por não-indígenas que possuem interesses econômicos nelas, não havendo políticas governamentais que prestem suporte aos indígenas desses territórios, muito menos que regule a exploração dos recursos naturais, buscando a sustentabilidade do meio ambiente e o bem estar de todos os brasileiros.

As relações entre os povos indígenas e o Estado brasileiro mudaram ao longo da história, tendo em seus registros desde uma política desenvolvimentista marcada por "assimilacionismo desenfreado", provocando a ação tutelar do Estado sobre os povos indígenas, até a garantia teórica da "cidadania" no arcabouço jurídico Estatal brasileiro (LIMA, 2012. p.172). As especificidades dos povos indígenas do Brasil encontram-se legalmente reconhecidas na Constituição da República Federativa de 1988, bem como a garantia do direito às suas organizações sociais, usos, costumes, tradições, direito ao território, capacidade para postular em juízo, legitimando com isso o direito às diferenças étnico-culturais (PACHECO, PRADO E KADWÉU, 2011).

É importante destacar que mesmo existindo contato entre indígenas e não indígenas as distintas identidades étnicas dos povos se mantêm em expressão no Brasil (PACHECO, PRADO E KADWÉU, 2011). Porém, o tempo de contato e interferência dos não-indígenas na cultura, vida e organização sociopolítica dos povos indígenas, bem como o contexto inóspito que se entende historicamente, provocaram diversas modificações nos seus padrões de vida e de articulação.

Compreender que dentro de uma sociedade existem várias outras, que se relacionam, promovendo conflitos, inclusões, exclusões, trocas, diferenças, dentre outras coisas, é essencial para analisar aspectos referentes à cultura e a sociedade, como afirma os autores Amaral e Baibich-Faria (2012). Diante disso, chamam atenção para a ideia equivocada de cultura imune, neutra ou isenta dos resquícios coloniais, o que apoia a ruptura da ideia que põe os povos indígenas à margem das 
modificações histórico-sociais, e os realocam imersos na contemporaneidade, num tempo histórico múltiplo e diferenciado.

Essa ideia se contrapõe ao ideário construído socialmente sobre os povos indígenas, veiculados em clássicos da etnologia brasileira e em livros didáticos, cinema, literatura e outras produções não-indígenas. Além dessa contraposição necessária, também contribui para a ampliação da consciência sobre os sistemas multissocietários e multilinguístico, que por si só já se constituem desafio diante do capitalismo. Destacam de um lado, as grandes modificações sofridas pelos povos indígenas durante o contato com não indígenas, e por outro a evidenciação de marcas identitárias étnicas características desses povos, que resistiram e permaneceram na história, como já citado por Pacheco, Prado e Kadwéu (2011).

A expressão do movimento indígena evidencia o protagonismo indígena como símbolo da busca por autonomia nos processos sociais que os envolvem. Expressam no seu cotidiano de luta necessidades extensas e interesses multifacetados, posto num cenário que se move a fim de provocar mudança social e que convive com as transformações aceleradas e as dissonâncias entre as gerações indígenas (LIMA, 2012).

Capiberibe e Bonilla (2015) chamam atenção para o papel da oralidade nas sociedades indígenas como instrumento de emissão de poder, sendo através da fala que os povos indígenas têm ocupado lugar de destaque como porta-vozes de suas causas e ideias no cenário político nacional e internacional. Esse protagonismo indígena envia mensagens claras ao Estado e aos não indígenas, que expõe a diferença dos indígenas em relação ao homem branco e a diversidade dos povos em relação à língua, aos modos de socialização, aos conhecimentos cosmológicos, aos regimes políticos e econômicos. A mensagem que vem do protagonismo indígena é única. Expõe a diferença e exige respeito à diversidade.

Como resultado da contraposição de interesses e ideais, tem-se de um lado o protagonismo indígena que resiste à opressão e ao racismo do Estado, lutando por condições dignas de vida e saúde, e de outro as inúmeras iniciativas impulsionadoras do "progresso" do país por meio, principalmente do agronegócio, que extermina com todas as perspectivas de preservação e sustentabilidade ambiental, bem como de garantia dos direitos de cidadania dos povos indígenas e outros povos tradicionais que vivem no Brasil.

Nesse embate de forças, os indicadores da saúde indígena se mostram 
desumanamente alarmantes, denunciando a situação de desigualdade e ausência de direitos vivenciada por estes povos atualmente, porém como reflexo do processo histórico anteriormente citado. Coimbra Jr. (2014) corrobora com essa leitura, ao destacar que a situação de saúde dos povos indígenas na atualidade nada mais é do que um produto da trajetória histórica que envolve diversos conflitos pela terra ligados à expansão das frentes demográficas nacionais, degradação ambiental, sinalizando também que em muitos casos ocorreu claramente a omissão do Estado.

As condições de saúde, refletidas no perfil epidemiológico dos povos indígenas, são bastante complexas. Contrapondo o comportamento de decréscimo das doenças infecto-parasitárias na população não indígena, nota-se a permanência delas enquanto importante causa da morbimortalidade de indígenas no Brasil. Exemplos disso são: a tuberculose, a malária, as infecções respiratórias agudas, as doenças diarreicas e o parasitismo intestinal.

A tuberculose (TB) no período de 2006 e 2007 apresentou incidência média em indígenas de 144,1 e 140,2 por 100 mil habitantes, respectivamente, extrapolando muito a média para o país que foi de 42 por 100 mil habitantes, valendo destacar que no ano de 2003 encontrava-se entre as 10 principais causas de morte nas comunidades indígenas. Dessa forma, não resta dúvida sobre a importância sanitária da TB para a análise da saúde dos povos indígenas (BASTA, ORELLANA, ARANTES, 2012).

A malária possui grande contribuição no adoecimento e morte dos povos indígenas, já sendo ligada, pelos pesquisadores da área, às alterações produzidas no meio ambiente, como às frentes de expansão econômica na Amazônia que traz a construção de hidroelétricas, abertura de estradas, mineração, etc., soma-se ao risco natural já existente, elevando consequentemente a exposição dos povos indígenas aos riscos de adoecer e morrer por malária (BASTA, ORELLANA, ARANTES, 2012).

Mundialmente, a pneumonia e as doenças diarréicas possuem destaque como causa da morte de aproximadamente $40 \%$ das crianças menores de cinco anos, em regiões desfavorecidas social e economicamente. No Brasil, a realidade das crianças indígenas nessa mesma faixa etária se aproxima desse panorama mundial. Basta, Orellana e Arantes (2012) evidenciam o parasitismo intestinal e as diarréias como causas permanentes e conhecidas de morbidade entre indígenas brasileiros. Ressaltam ainda a interligação direta dessas morbidades com as 
precárias condições de saneamento, degradação ambiental, restrição territorial, inadequada e baixa efetividade de programas de saúde nas áreas indígenas.

Outro ponto relevante que marca o perfil epidemiológico dos povos indígenas é o processo de surgimento e expansão das Doenças Crônicas Não Transmissíveis (DCNT), como, diabete mellitus tipo II, hipertensão arterial, dislipidemias, obesidade e câncer. Pesquisadores da área atribuem essa mudança epidemiológica à alteração no hábito de vida, o que inclui o sedentarismo, mudança no padrão alimentar, dentre outros fatores (BASTA, ORELLANA, ARANTES, 2012). Vale destacar que, as modificações no modo de vida dos povos indígenas foram desencadeadas pelos processos de dominação e opressão impostos pelos não-indígenas, sendo acirrada com a invasão dos territórios ancestrais e consequente aldeamento das diversas etnias.

As ditas "doenças sociais", como o alcoolismo, os transtornos psiquiátricos, os suicídios e as mortes por causas externas compõem as DCNT e se apresentam em tendência crescente no Brasil. O suicídio entre os povos indígenas já foi relatado em diversas etnias brasileiras. Segundo informações do Distrito Sanitário Especial Indígena (DSEI) do Mato Grosso do Sul, entre 2000 e 2007 a taxa média de suicídios foi de 78,3 por 100 mil habitantes. Desses, as maiores taxas foram encontradas entre os povos Guarani Kaiowá e Nhandeva, com taxa média de 118,4 por 100 mil (BASTA, ORELLANA, ARANTES, 2012).

A mortalidade por causas externas no Brasil, o que inclui agressões por arma de fogo e por materiais perfurocortantes, acidentes, suicídios, dentre outros, são elevadas entre os indígenas, representando no ano de 2003, de acordo com a Funasa, $16,8 \%$ da notificações, sendo assim a segunda causa morte entre indígenas e concentrando-se em indivíduos com idades entre 10 e 39 anos. Do total de mortes por causas externas, $26,6 \%$ foi por suicídio, $24,5 \%$ por acidentes e $23,9 \%$ por agressões. Essas causas de mortalidade denunciam a sua ligação direta com problemas sociais como o alcoolismo, a violência e a desestruturação social, bem como com a inconsistência das políticas públicas para os povos indígenas (BASTA, ORELLANA, ARANTES, 2012).

Os altos índices de mortalidade por causas externas no estado de Mato Grosso do Sul são exemplos desse quadro alarmante. Segundo Capiberibe e Bonilla (2015), as insuficientes terras demarcadas e os acampamentos indígenas são palco de problemas complexos e persistentes como a desnutrição crônica, taxas de suicídio 
19 vezes maior à taxa nacional, alcoolismo, uso de drogas, discriminações, violências físicas e atropelamentos. Destaque deve ser dado ao número elevado de assassinato de lideranças, rezadores e representantes indígenas.

Ferreira, Matsuo e Souza (2011) ao analisarem alguns dos indicadores de saúde da população indígena do Mato Grosso do Sul, apontou a mortalidade por causas externas como a principal causa de morte entre indígenas nos anos de 2004$2006(22,4 \%)$. Na faixa etária entre 5-39 anos foram responsáveis por mais de 60\% das mortes, tendo coeficiente de mortalidade maior que na população total, em ambos os sexos, e 3,11 vezes maior entre as mulheres que entre homens $(1,87)$. A principal causa foi o suicídio entre indígenas de 10 a 24 anos. Vale ressaltar que 0 genocídio dos povos indígenas no Brasil, movido pelo racismo, parcialidade do Estado e pelos interesses econômicos já se constitui em problema de saúde pública, ainda que não seja encarado assim pelo Estado e pela sociedade em geral.

Carlos Coimbra Júnior (2014) corrobora com estes dados e acrescenta informações epidemiológicas relevantes sobre os povos indígenas, ao fazer a leitura inicial do Inquérito Nacional de Saúde e Nutrição Indígena realizado entre os anos de 2008 e 2009. Segundo o autor, esse Inquérito aconteceu com décadas de atraso, considerando que os povos indígenas foram excluídos das pesquisas nacionais e regionais realizadas com a população não-indígena desde a década de 1970. Assim, o Inquérito Nacional objetivou caracterizar o estado nutricional de mulheres entre 14 e 49 anos e crianças até cinco anos de idade, por meio de amostra probabilística representativa da população indígena de quatro macrorregiões (norte, nordeste, centro-oeste e sul/sudeste). A pesquisa envolveu 113 aldeias, 6.692 mulheres e 6.128 crianças.

O Inquérito apontou para intensas iniquidades em saúde entre o "Brasil indígena" e o "Brasil Não-Indígena". Evidenciou a intensa deficiência em saneamento básico, presente até em comunidades próximas à centros urbanos, o que inclui ausências ou deficiências nos campos referentes à: água potável para consumo, manejo do lixo e instalações sanitárias. Evidenciou também desnutrição crônica nas crianças, refletida pelo déficit de crescimento para idade presente em 1/4 das crianças examinadas $(25,7 \%)$, o que na região norte alcançou o percentual de $40,8 \%$ de déficit estatural. A prevalência de anemia em crianças foi de $51,2 \%$, sendo mais alta na região norte $(66,4 \%)$, o que contrasta mais uma vez com as referências de crianças não-indígenas brasileiras, em que a prevalência é de $20,9 \%$. Além dos 
déficits nutricionais, foi constatada elevada prevalência de hospitalização por condições sensíveis à atenção básica nos 12 meses que antecederam a pesquisa de campo (diarreia, 37,2\%) e infecção respiratória aguda $(47,6 \%$ ) (COIMBRA JR., 2014).

O estado nutricional da mulher indígena revelado no inquérito apontou sobrepeso ou obesidade em $46 \%$ das indígenas participantes da pesquisa, porém a prevalência de anemia entre elas se mostrou elevada, estando presente em 32,7\% das mulheres e chegando a $46,8 \%$ de prevalência na região norte. Associado a estes dados, considerou-se a alta taxa de fecundidade das mulheres indígenas que tem por volta de 8 filhos e que não contam com serviço de pré-natal de forma regular, no que tange a cobertura e a qualidade (COIMBRA JR., 2014), podendo impactar, ou já impactando, negativamente nos indicadores de saúde materno infantil entre as indígenas do Brasil.

Carlos Coimbra Jr. (2014), numa leitura real e acertada sobre as disparidades sociais que cercam os povos indígenas no quesito saúde e vida, afirma que:

\footnotetext{
Ser indígena no país implica maior chance de não completar o primeiro ano de vida, sofrer de desnutrição e anemia durante o período de crescimento, conviver com elevada carga de doenças infecciosas e parasitárias e estar exposto a rápido processo de transição nutricional, responsável pela emergência de agravos como a obesidade, hipertensão arterial e diabetes mellitus, constatados em número crescente de comunidades (COIMBRA JR., 2014, p. 856).
}

Basta, Orellana e Arantes (2012), reforçam que as evidentes iniquidades em saúde referentes aos povos indígenas, expressas pelos dados e informações epidemiológicas, revelam diversas problemáticas de relevância, ligadas à falta de acesso às condições adequadas de saneamento básico e moradia, à segurança alimentar e nutricional, às políticas públicas de desenvolvimento social e econômico e às ações integrais de cuidados à saúde dos povos indígenas. Tomando como referência a fala dos autores, é possível questionar o real direito de cidadania dos povos indígenas no Brasil diante desse contexto sócio histórico tão desfavorável. Será suficiente apenas o arcabouço jurídico para que a cidadania seja de fato real? Desta maneira cabe, no mínimo, o questionamento: será o “índio cidadão?”. 


\section{2 ÍNDIO CIDADÃO?}

"Ser indígena significa que el proyecto de Estado nación no triunfó, [..], que el territorio no es único, que la lengua no es única y que no hay una sola ciudadanía." (Gladys Tzul, liderança Maya e cientista política)

A reprodução cotidiana dos conceitos de cidadania embutidos na população brasileira extrapolam os corpos individuais e ganham o coletivo nos debates e em construções diversas. Comumente os discursos vão em direção à garantia do direito de cidadania, misturando conceitos de justiça social, equidade, direitos sociais, iniquidade em saúde, dentre outros (CARVALHO, 2002; LAVALLE, 2003; SOUZA, 2003). Porém, a ideia da cidadania propagada nos discursos não possui aprofundamento na diversidade do povo brasileiro, expondo nas entrelinhas a ideia de único povo e de inexistência de particularidades (SOUZA, 2003; CARVALHO, 2002; LAVALLE, 2003) e iniquidades raciais, orquestrado pela "miscigenação".

Sérgio e Lilia Tavolaro (2010) reconhecendo o antagonismo entre os europeus, indígenas e africanos, reafirmam tal antagonismo na perspectiva de uma amortização dramática das diferenças por meio da miscigenação dos povos. Porém, essa forma de análise é contestável, considerando que, no Brasil, a miscigenação enfraqueceu os povos indígenas e o povo negro, pulverizou a história dos povos em partículas dispersas e invisíveis e contribuiu para o grande mito da democracia racial.

Segundo Guimarães (2001), a democracia racial é considerada uma ideologia de dominação, apresentando-se como um modo cínico e cruel de manutenção das desigualdades socioeconômicas entre brancos e negros (e indígenas), ocultando a manutenção do preconceito de cor e das discriminações raciais. Conhecer a história do Brasil e consequentemente sob que bases o mito da democracia racial foi fundamentado permite a crítica aplicada às noções, conceitos e políticas existentes, já que todas elas foram forjadas no bojo de um Estado racista, genocida e etnocida. A cidadania não deve se colocar longe desse objetivo, exigindo, para debates minimamente coerentes, a leitura racializada da questão.

As reflexões aqui apresentadas tentam provocar reflexões e/ou apontamentos 
acerca de duas questões: $1^{\circ}$ ) Qual o (s) conceito (s) de cidadania utilizado (s) no Brasil? e $\left.2^{\circ}\right)$ Os povos indígenas do Brasil, de fato, são cidadãos?

\subsubsection{Alguns elementos conceituais da cidadania no Brasil}

A cidadania no Brasil, em seu campo conceitual, foi abordada por José Murilo de Carvalho em uma de suas obras, intitulada Cidadania no Brasil: o longo caminho (2002). O autor pontuou aspectos importantes para a construção da cidadania no território brasileiro, porém provocou uma série reflexões e inquietações ao abordar a cidadania sem racializar o debate, apontando a chegada dos portugueses no Brasil como a conquista das terras brasileiras e não como uma invasão, o que gera contraponto inevitável.

A dizimação ocorrida com os povos indígenas do Brasil equivale, em termos de comparação, a redução da população da Europa da época em quase sua totalidade. Então, isso parece algo assimilável como a conquista de uma terra? A noção de dominação impregnada e naturalizada nesse contexto histórico e no referencial teórico sobre cidadania no Brasil apontado por Carvalho (2002), expõe a supremacia dos europeus como detentores dos mecanismos de poder e dominação, legitimada e naturalizada entre a sociedade dominante e dominadora e atualmente reproduzida e naturalizada amplamente entre os brasileiros.

Todos os fatores ligados à invasão e colonização do Brasil pelos europeus explicam não só as modificações sofridas pelos povos indígenas, como apontadas no capítulo 2.1, mas também e principalmente as bases sócio históricas que formaram o Brasil, dando a "forma do branco", a "forma do dominador". Então, considerando o Brasil o berço de uma das maiores barbáries da humanidade, como falar em cidadania sem explorar a história do Brasil e de seu povo originário? Como enxergar o povo brasileiro como um só, sem exaltar suas particularidades sócio históricas e culturais?

Leituras que não considerem o componente racial na estruturação dos conceitos de cidadania no Brasil ofertam apenas uma visão parcial e superficial da reflexão e que traz para a dimensão da naturalização o massacre ocorrido nessas terras. Seria então o conceito de cidadania representante das características 
históricas do Brasil? Seria ele representativo dos povos que não só habitam o Brasil, mas que o originaram?

Para responder a essas questões torna-se importante conhecer as bases conceituais utilizadas para definir a cidadania no Brasil, para a partir disso analisar criticamente os compassos ou descompassos da cidadania para os povos indígenas. Carvalho (2002) aponta a cidadania como o conjunto composto pelos direitos civis, políticos e sociais, o que demonstra a complexidade do conceito.

Esquadrinhando as três partes que a compõem, tem-se: os direitos civis representando àqueles fundamentais à vida, à liberdade, à propriedade, à igualdade perante a lei, como por exemplo, o direito de ir e vir, de escolher o trabalho, de manifestar os pensamentos e ideias, de organizar-se, de não ser preso a não ser por autoridade competente e em acordo com a lei, de ter respeitada a inviolabilidade do lar e da correspondência, dentre outros (CARVALHO, 2002).

Os direitos políticos se referem à participação do cidadão no governo, englobando a possibilidade de fazer demonstrações políticas, de organizar partidos, de votar e ser votado. Oswaldo Ruiz Chiriboga (2006), advogado da Corte Interamericana de Direitos Humanos (IDH), aponta os direitos políticos como resultado de 3 (três) grandes fatores, de acordo com o artigo 23ำ da Convenção Americana de Direitos Humanos (CADH), são eles: 1 - a participação em direção a assuntos públicos; 2 - o direito de eleger e ser eleito em condições livres e democráticas; e 3 - ter acesso, em condições de igualdade, às funções públicas do país.

Por último, porém não menos importantes estão os direitos sociais, que se baseiam na justiça social, buscando reduzir o excesso de desigualdades geradas pelo sistema capitalista. Segundo Carvalho (2002), os direitos sociais deveriam garantir a participação nas riquezas coletivas, cabendo aqui a reflexão: no sistema capitalista existe espaço para as ditas "riquezas coletivas", se a lógica que comanda é a de mercado, da competitividade, em prol dos interesses individuais das minorias abastadas? Nesse campo está inserido o direito à educação, ao trabalho, ao salário justo, à saúde, à aposentadoria, etc. (CARVALHO, 2002).

Trazendo a educação e o trabalho para a realidade brasileira põe-se a seguinte questão: brancos, indígenas, negros e amarelos possuem as mesmas oportunidades de formação e inserção no mercado de trabalho, já que teoricamente todos são cidadãos? Logicamente o trabalho e a educação como direito social 
componente da cidadania deveria ser real para todas as raças e etnias, no mínimo no que tange a igualdade de oportunidades.

Duarte (2010) explicita a incompatibilidade da cidadania com as sociedades capitalistas, tendo essa lógica como impeditivo claro para o seu desenvolvimento. Reforça que a cidadania é uma representação idealizada que não tem força suficiente para superar a alienação das relações sociais, que têm o dinheiro como mediação universal em nossa sociedade, sendo nessas condições apenas uma idealização desprovida de conteúdo real. Essa leitura parece coerente diante dos valores impostos pelo capitalismo, a exemplo do individualismo, do consumo, da competitividade, da concentração de riquezas, o que põe à prova as ditas riquezas coletivas como campo fértil para a garantia dos direitos sociais.

Sendo assim, não seria recomendável esperar o surgimento das riquezas coletivas para que a garantia dos direitos sociais seja efetivada, e sim, abrir espaço para as medidas de reparação, ancoradas na justiça social. Ribeiro (2015) avalia que a justiça social está ligada a noção de igualdade na distribuição de bens na sociedade, sendo essa noção já problematizada em 2001, por Amartya Sen, em sua obra desigualdade reexaminada. $\mathrm{O}$ autor ao analisar a justiça social à luz da diversidade que envolve os indivíduos, pôs a seguinte questão: $O$ que deve se igualar para que haja justiça? Seriam os bens primários, as liberdades, os recursos ou as capacitações? É notável a pluralidade conceitual e de defesas que existem no campo (RIBEIRO, 2015), o que o torna inacabado e em constante movimentação.

Lavalle (2003) apresenta os teóricos que mais influenciaram a conhecida cidadania moderna, T.H. Marshall (1949) e Reinhart Bendix (1964), sendo marcada, por exemplo, pelo dito modelo evolutivo de Marshall, representado pelo alargamento da cidadania como status de direitos atribuídos - direitos civis se desdobrando em políticos e estes em sociais. Porém, nem mesmo as características constitutivas da cidadania moderna dão conta das contradições que se apresentam quando falamos de cidadania num território violado como o Brasil.

Adrián Lavalle (2003) cita uma das falas de Marshall sobre o tema: A cidadania é um status concedido àqueles que são membros integrais de uma comunidade, todos aqueles que o possuem são iguais com respeito aos direitos e obrigações pertinentes ao status. Este conceito é nitidamente excludente, uma vez que concebe a comunidade nacional como elemento único, sem pluralidade, sem diferenças, o que abre espaço para questionamentos, quando possui como pano de 
fundo o contexto histórico de construção do Brasil, se tornando vulnerável, principalmente no que diz respeito a sua adoção na totalidade para a discussão e construção da cidadania para os povos indígenas.

Lavalle (2003) rememora que a lógica liberal deste conceito trazido por Marshall foi questionada pelo marxismo, devido à falta de formulações que dessem conta do status sócio-político moderno no contexto de dominação do Estado-nação e pela escassa atenção dada aos conflitos sociais envolvidos no reconhecimento de novos direitos. O autor, apesar de reconhecer este campo de discordância e crítica nomeando como parcialmente correto, explica a divergência pela centralidade que cada autor dá a sua crítica, Marx na luta de classes e Marshall no papel da cidadania para a consolidação do Estado. Pontua que mesmo com estas e outras críticas menos usuais, a síntese trazida por Marshall e a reformulação proposta por Bendix permanecem como referenciais centrais no debate sobre a cidadania.

Essa defesa de Adrián Lavalle (2003) não se mostra suficiente para a discussão aprofundada da cidadania no Brasil e consequentemente para a cidadania dos povos indígenas. Portanto, para dar conta das questões raciais como estruturantes desse processo de análise - eixo central na construção do Brasil - nem Marshall, nem Bendix, nem Marx. Os dois primeiros pelas suas construções centradas no Estado-nação enquanto unidade, portanto excludente da diversidade étnico-cultural dos povos indígenas, e o último pela leitura de classe enquanto categoria central para entendimento das relações de dominação e poder na sociedade, negando a raça enquanto estruturante dessas relações.

É preciso reconhecer que a questão racial no Brasil é estruturante de todos os processos e construções que se referem ao Estado, à cidadania, à democracia, à equidade, considerando que o pensamento colonizador se reproduz até os dias de hoje nos conceitos e políticas. Reconhecer isso é o mesmo que dar um passo à frente para entender alguns dos nós críticos históricos para a garantia de direitos civis e sociais, para a evolução e coerência do conceito de equidade e cidadania, dentre tantos outros. Possivelmente esta leitura aqui apresentada seria caracterizada pelo Adrián Lavalle como uma crítica menos usual, o que seria um caminho rumo à manutenção da incoerência que reside na fuga do debate racializado da cidadania.

Assim, vale sempre uma pergunta ao ler referenciais teóricos nessa temática: cidadania para quem? É importante se permitir reflexão profunda, colocando como 
eixo central de análise a questão racial e especificamente os povos indígenas do Brasil.

\subsubsection{Cidadania para os povos indígenas do Brasil}

A reflexão sobre a cidadania ou a não cidadania dos povos indígenas no Brasil se assenta sob um cenário histórico de massacre e violações de direitos, como evidenciado no capítulo 2.1, que trata sobre os povos indígenas.

A luta pela cidadania é árdua e contínua para os povos indígenas do Brasil. Luta para garantir os direitos civis, políticos e sociais, luta pelo direito de viver dignamente, de acordo com suas especificidades culturais, direito à cultura ancestral, à identidade (MOTA, 2008). Mas como lidar com o diferente numa sociedade que prega a igualdade? Como pensar em cidadania para povos tão diversos entre si e perante os outros? Sendo assim, seria possível dizer que os povos indígenas do Brasil possuem o direito pleno à cidadania? Poderíamos considerá-los cidadãos plenos, incompletos ou não cidadãos?

De imediato, rememorando os pontos abordados no capítulo 2.1 e fazendo uma leitura rápida da história do Brasil e dos conflitos e massacres que permanecem até os dias de hoje, é possível perceber que os direitos civis dos povos indígenas são violados em diferentes partes do país. Não existe e nunca existiu direito a propriedade e o respeito à inviolabilidade do lar, já que o roubo dos territórios ancestrais foi realizado pelos brancos que fundaram o Estado, e atualmente, ainda é referenciado com a glória da conquista, palavra utilizada por Carvalho (2002).

Não existe e nunca existiu a igualdade perante a lei para os povos originários. Para constatar isto basta observar a situação do estado do Mato Grosso do Sul, que apresenta a segunda maior população indígena do Brasil e que mesmo assim possui índices alarmantes de genocídio e violência contra os povos indígenas, já que tem sua economia baseada no agronegócio (CAPIBERIBE, BONILLA, 2015; FERREIRA, MATSUO, SOUZA, 2011).

Esse contexto complexo envolvendo de um lado os povos originários e de outro os não indígenas que se utilizam do agronegócio trouxe marcas históricas para os povos indígenas e para a natureza, o que segundo Capiberibe e Bonilla (2015) é 
representado por perda brutal de condições essenciais de vida: expropriação de suas terras, contaminação das águas e do ar, confinamento em reservas e espaços minúsculos, etc.

As autoras apontam o agronegócio como um modelo de sociedade e não apenas como um modelo produtivo como alguns defendem. Os rastros desse modelo são notáveis, envolvendo impactos negativos no meio ambiente e nas populações tradicionais e originárias, como é o caso dos povos indígenas. O cultivo de soja, milho, cana-de-açúcar, bem como a criação extensiva de gado de abate gera poluição dos lençóis freáticos, intoxicação de trabalhadores por agrotóxicos (PIGNATI, 2007), contaminação do solo e água, emissão de gazes de efeito estufa, desmatamento, expulsão das populações originárias e tradicionais, violências e massacres intensos (CAPIBERIBE; BONILLA, 2015).

Os conflitos fundiários no Mato Grosso do Sul são marcados por violações de direitos humanos e racismo contra os povos indígenas. $O$ interessante é desnudar a "mão" do Estado nesse massacre. Capiberibe e Bonilla (2015) rememorando a história do estado, apontam que o governo brasileiro, após a guerra do Paraguai (1864-1870) povoou as terras do Mato Grosso do Sul com populações não indígenas, considerando-as como um amplo espaço vazio.

Esse fato evidencia a ação genocida do Estado brasileiro, que usurpou os territórios ancestrais indígenas para impulsionar as frentes agropastoris na região, gerando o massacre histórico dos povos indígenas, com destaque para o vivenciado pelos Guarani e Kaiowás (CAPIBERIBE, BONILLA, 2015). Então, onde está a inviolabilidade do lar para os povos indígenas, como constituinte dos direitos civis? É isso que chamam de direitos de cidadania?

O Relatório sobre violências contra os Povos Indígenas elaborado pelo Conselho Indigenista Missionário (CIMI, 2012) apontou o Mato Grosso do Sul como estado que mais assassina indígenas. No ano de 2012 o Brasil teve 60 assassinatos de indígenas, dentre os quais 37 foram no Mato Grosso do Sul, sendo 34 da etnia Guarani e Kaiowá, 2 Terena e 1 Ñandeva. Se considerarmos o período de 2001 a 2012 foram 372 indígenas mortos no estado, o que levou o Ministério Público Federal a elaborar um Termo de Ajustamento de Conduta (TAC), assinado pela Funai como representante do governo federal, a fim de identificar 36 novas Terras Indígenas ( $\mathrm{TI}$ ), tornando evidente que o problema fundiário é o nó crítico que afeta os Guarani e Kaiowá. De acordo com Capiberibe e Bonilla (2015), 
As terras indígenas fazem parte de um quadro mais amplo de disputas envolvendo a questão fundiária, que opõe, de um lado, não exatamente de maneira orgânica, o agronegócio, a mineração, as políticas de desenvolvimento econômico do Estado, gestores públicos ligados ao setor agrícola e mineral; e, de outro, populações indígenas, quilombolas, populações tradicionais (caboclos, ribeirinhos, seringueiros, castanheiros), ambientalistas, antropólogos e indigenistas com diversas formações e origens (CAPIBERIBE; BONILLA, 2015, p. 295).

Assim, esses movimentos para enfrentamento das violações dos direitos civis e sociais dos povos indígenas, a exemplo do TAC supracitado, por se encontrarem assentados em um palco de disputa econômica e política, ressoam no Congresso Nacional, gerando medidas anti-indígenas, a exemplo do Projeto de Lei (PL 349/2013) proposto pela senadora Katia Abreu, figura conhecida do agronegócio na bancada ruralista, que pretendia criminalizar as reocupações, por meio de punições que significariam o adiamento da demarcação da TI em questão (CAPIBERIBE; BONILLA, 2015).

$\mathrm{Na}$ correlação de forças em torno da disputa pelos recursos naturais, os povos indígenas encontram-se em franca desvantagem. Está claro que não contam com o apoio incondicional de nenhuma das pontas que formam o Estado. A impunidade que acoberta os assassinos e mandantes das mortes indígenas significa a manutenção desse estado precário de direitos (CAPIBERIBE; BONILLA, 2015, p. 306).

As autoras denunciam o impacto do crescimento da produção agropastoril na região centro-oeste do Brasil na vida de alguns povos indígenas, com seu avanço intenso contra a Amazônia. Chamam atenção para o desmatamento no Acre e no Sul do Amazonas, que atinge as terras indígenas do povo Katauixi (povo isolado) e a TI Caititu, do povo Apurinã. Esse fato provocou intensificação dos conflitos agrários, seguido de dezenas de assassinatos na última década (CAPIBERIBE; BONILLA, 2015).

Os exemplos do Mato Grosso do Sul, Acre e Amazonas sinalizados aqui, associados a outros que ainda não ganharam corpo na literatura científica, como os casos dos conflitos fundiários que ocorrem na Bahia com os povos Tupinambá e Pataxó, que também apresentam contexto de violação de direitos, massacre e racismo, sinalizam a situação de não cidadania dos povos indígenas no Brasil. Diante destes acontecimentos, não caberia uma rediscussão sobre a cidadania para os povos indígenas? 
No campo do direito político, apesar de existir a garantia aos povos indígenas de votar e ser votado, a participação por meio da democracia representativa se torna frágil e insuficiente, principalmente pelo conflito de interesses existente entre os povos indígenas e os parlamentares. Capiberibe e Bonilla (2015) apontam a política e o modelo econômico como os dois âmbitos em que os direitos indígenas são tratados há séculos no Brasil. Destacando ainda que os indígenas são vistos como entraves ao desenvolvimento econômico, o que é denominado por elas como tempos sombrios para quem não crê no modelo de desenvolvimento calcado no capital.

A crise da representação política dos povos indígenas se agrava pela falta de representatividade de indígenas no poder legislativo e escassez no executivo (CAPIBERIBE, BONILLA, 2015). As defesas políticas alienadas do princípio da justiça social podem comprometer a garantia dos direitos, principalmente quando se trata dos povos que foram prejudicados historicamente pelo Estado e que, por questão de reparação social, precisam de políticas que revertam os prejuízos e as iniquidades geradas pela dominação dos brancos sobre os povos indígenas e o povo negro.

Oswaldo Chiriboga (2006) aponta a falta de representação política como uma das principais causas de marginalização e pobreza dos povos indígenas, sendo por si só a própria violação da autodeterminação e participação política nos níveis local, regional e nacional. Destaca ainda que a participação direta dos povos indígenas na direção de assuntos públicos deve acontecer a partir de suas próprias instituições e de acordo com seus valores, usos, costumes e formas de organização, sendo esta uma forma de preservação e sobrevivência da cultura.

Para tanto, o Comitê para a Eliminação da Discriminação Racial (CERD), da Organização das Nações Unidas (ONU), recomendou aos Estados tomar medidas que permitam que membros de comunidades indígenas sejam escolhidos em eleições, considerando os índices muito baixos de representação política e também as condições desiguais de participação em todos os níveis de poder. A Corte Interamericana de Direitos Humanos destacou como entrave importante a obrigatoriedade de a participação política ser feita por meio de partidos, não permitindo a participação via outros agrupamentos, o que poderia melhor corresponder à diversidade de organização sociopolítica e cultural dos povos indígenas (CHIRIBOGA, 2006). 
Esse fato representa limitação dos direitos políticos dos povos indígenas, porém não deve conduzir ao pensamento de que a representação significaria a totalidade da participação política dos indígenas, já que mesmo necessária seria insuficiente para proteção de direitos e interesses se utilizada isoladamente. Chiriboga (2006) defende que os povos indígenas têm o direito a dar seu consentimento prévio, livre e informado sobre todos os assuntos que os envolvem e interessam. Só desta forma Ihes será permitido falar por si mesmos, participar do processo da tomada de decisões e contribuir positivamente com o país em que vivem.

Carvalho (2002) destaca que a construção da cidadania tem a ver com a relação das pessoas com o Estado e com a nação, afirmando que essa construção acontece quando as pessoas começam a se sentir parte da nação e leais ao Estado. Lavalle (2003) corrobora com o autor quando afirma que o status de cidadania se configura a partir do conjunto de iguais que formam a comunidade política, a identidade homogeneizada. Carvalho (2002) explica que a identidade nacional depende de diversos fatores, como a religião, a língua, e, sobretudo, as lutas e guerras contra inimigos comuns, ao passo que a lealdade ao Estado, também constituinte do referencial teórico da cidadania, se liga ao grau de participação na vida política.

Carvalho (2002) chama atenção para a interferência da maneira como se forma o Estado-nação na construção da cidadania, sendo de extrema importante para a reflexão que cerca o contexto histórico do Brasil e o desenvolvimento do pertencimento e lealdade. Não existe e nem deve existir unidade quando se fala em nação brasileira. A ideia integracionista que pregava a assimilação dos povos indígenas ao Estado nacional fragilizou os povos, tentou diluir a cultura e a identidade, porém foi vencida pela resistência dos povos originários.

A inacessibilidade dos direitos civis que constituem a base da sequência de Marshall é presente ainda nos dias atuais para a maioria da população, sendo evidenciada por Carvalho (2002). Tal fato abre uma importante janela de oportunidade para a discussão racializada do debate sobre a cidadania e consequentemente a evidenciação da não cidadania ou da cidadania incompleta para indígenas e negros no Brasil.

Todos esses pontos se ligam ao debate sobre a democracia ou a ineficácia desse sistema, como citado por Carvalho (2002), e ao tipo de democratização do 
poder que precisamos no Brasil. Assim, no intuito de construir caminhos possíveis para a diminuição das contradições referentes à cidadania, vale pôr relevo na "redemocratização do poder" fundamentada na questão racial como categoria estruturante, permitindo o enfrentamento de iniquidades históricas produzidas pelo Estado e a aproximação do conceito de cidadania à realidade dos povos que aqui vivem. Enfrentar a realidade de desigualdade e massacre que norteou e ainda norteia todas as construções políticas e sociais no Brasil deveria ser um elemento norteador da compreensão dos processos e apontamentos de outras formas de organização e ação do Estado.

Dessa forma, essas pontuações trazidas na presente dissertação, evidenciam que os povos indígenas do Brasil enfrentam situações históricas de genocídio, etnocídio, racismo, exclusão social e diversas outras formas de violações dos direitos civis, políticos e sociais (CAPIBERIBE, BONILLA, 2015; CHIRIBOGA, 2006; FERREIRA, MATSUO, SOUZA, 2011), o que os torna, há 516 anos, sujeitos não portadores de direitos reais e em muitos casos não cidadãos. Apresenta-se assim um convite à reflexão, que não é simples ou rasa, mas que pode apoiar a luta pela efetivação da cidadania para os povos indígenas brasileiros.

Torna-se claro que sem a garantia da cidadania aos povos indígenas, não se garante também o acesso à formação e ao mercado de trabalho, já que o trabalho e a educação são direitos sociais intrínsecos à cidadania. Essa compreensão reconhece que esses aspectos estão intimamente imbricados, por serem ligados em sua origem, e evidencia a necessidade da promoção da igualdade de oportunidades, como forma de reverter os prejuízos históricos decorrentes das relações raciais no Brasil.

Assim sendo, a discussão sobre a presença de indígenas no ensino superior e no mercado de trabalho em saúde ganha relevância quando realizada à luz dos direitos de cidadania. Reflexões que evidenciem a relação entre as garantias de cidadania postas nas teorias e leis e àquelas efetivadas no cotidiano da vida dos povos indígenas são de extrema importância, destacando o acesso à formação universitária e ao trabalho, nesse caso específico, na assistência à saúde no Brasil. 


\subsection{FORMAÇÃO DE INDÍGENAS NO ENSINO SUPERIOR}

A qualificação profissional dos povos indígenas tem sido apresentada ao governo brasileiro como demanda frequente, principalmente no que tange à preparação de indígenas para atuar na defesa de suas próprias pautas estratégicas, por meio da participação em espaços de poder e de saber. Amaral e Baibich-Faria (2012) citam a emergência do ensino público superior como requerimento do movimento indígena nacional, tornando a universidade alvo de direito e espaço potencial a ser ocupado pelos povos indígenas como sujeitos históricos e epistêmicos. Segundo Lima (2012), os indígenas estão substituindo arcos e flechas, bordunas, enxadas e machados por canetas, computadores e diplomas, trazendo uma ideia de adaptação dos instrumentos e meios de luta política.

Para o Indígena Gersem dos Santos Luciano, da etnia Baniwá, Doutor em Antropologia Social,

[...]com o advento do processo de redemocratização do país, com a conquista do direito de cidadania plena (superando a visão de incapacidade civil dos índios) e a emergência do protagonismo indígena, a formação escolar, e principalmente a formação universitária, passou a ser uma das principais bandeiras de luta dos povos indígenas. Esta mudança de estratégia revela 0 momento atual do movimento indígena brasileiro pautado pelo abandono da tática defensiva de isolamento em seus territórios, que marcou séculos passados, e por maior aproximação, participação e envolvimento na vida nacional, que, obrigatoriamente, envolve a capacidade de estabelecer alianças, diálogos, negociações e intervenções em todas as políticas públicas que lhes dizem respeito. Umas das justificativas da importância com que é considerada a formação universitária é a necessidade de habilitar jovens indígenas para o debate qualificado no âmbito da própria academia, como centro de saber e poder ocidental e das políticas governamentais, além, é claro, da importância do acesso e da apropriação dos conhecimentos técnicos e tecnológicos que podem contribuir para a melhoria das condições de vida dos povos indígenas, impactados negativamente pela redução, invasão e destruição de seus territórios e de seus recursos naturais (LUCIANO, 2009. p. 32).

Segundo Amaral e Baibich-Faria (2012), a presença de indígenas no ensino superior já é realidade, apesar de se configurar como movimento recente no Brasil, concentrando-se principalmente nos últimos 10 anos. Atribuem tal fato à ampliação da escolarização de crianças, jovens e adultos em terras indígenas, que segue como consequência do reconhecimento da educação escolar indígena na Lei de Diretrizes e Bases da Educação Nacional de 1996, no Plano Nacional de Educação de 2001 e 
nas Diretrizes Nacionais de Educação Escolar Indígena no Brasil (AMARAL, BAIBICH-FARIA, 2012).

A linguística Bruna Francheto (2001 apud SILVA, MARQUES, 2016) refaz o percurso histórico que envolve a escolarização de indígenas no Brasil. Aponta importantes elementos que apoiam o entendimento do contexto de construção da formação indígena, em todos os seus níveis, o que inclui a formação no ensino superior. Sendo assim, revisitar a história se faz essencial para realizar a leitura real das respostas do Estado junto aos povos indígenas no campo da educação, entendendo inclusive a intenção embutida em cada uma das ações e políticas. A autora cita quatro fases históricas que constituíram o processo de escolarização dos povos indígenas no Brasil, expostas a seguir.

A primeira fase da escolarização dos indígenas no território brasileiro foi marcada pelo uso da educação como instrumento para catequizar os povos indígenas, objetivando extinguir seus conhecimentos, sua cultura e sua religião, tendo como marca a imposição dos costumes europeus, no período colonial (FRANCHETO, 2001 apud SILVA, MARQUES, 2016).

A segunda fase buscava a integração dos indígenas à dita comunhão nacional, tendo como parceiros do Estado os órgãos indigenistas oficiais, como o Serviço de Proteção aos Índios (SPI) e posteriormente a Funai, que executando política integracionista buscava transformar os indígenas em trabalhadores rurais, tendo como marca importante do período a imposição da educação formal, por meio da construção compulsória de escolas dentro dos territórios indígenas e da sobreposição da língua portuguesa (estrangeira) sobre as demais línguas originárias do Brasil (FRANCHETO, 2001 apud SILVA, MARQUES, 2016). A educação nessa fase pregava a homogeneização dos indivíduos e assim o extermínio daquilo que era diferente do europeu, do que se apresentava como essência dos povos brasileiros, aqueles originários do Brasil.

A terceira fase do processo de escolarização dos indígenas é marcada pela participação de Organizações Não Governamentais (ONGs) e de universidades na realização de encontros voltados à temática, buscando projetos alternativos. $\mathrm{Na}$ quarta fase, a autora aponta um elemento potencializador das discussões, o protagonismo indígena, por meio dos movimentos sociais indígenas. Os encontros destinados à temática passaram a ser organizados por professores indígenas e as discussões aconteceram aliadas à movimentação política pelo direito à educação 
diferenciada, à saúde, à (re)ocupação das terras tradicionalmente habitadas, etc. (FRANCHETO, 2001 apud SILVA, MARQUES, 2016).

Assim sendo, as etapas que compuseram a educação escolar para indígenas no Brasil, trazida por Bruna Francheto, apontam diversos elementos de importância para a compreensão dos princípios, formas e métodos que regeram a construção da educação no território brasileiro. Percebe-se uma forte herança sócio histórica da educação como instrumento de dominação, de docilização, de opressão, de formatação e homogeneização dos povos originários do Brasil, corroborada também por Garlet, Guimarães e Bellini, (2010).

Tal processo explica porque até meados de 1980 existia no Brasil uma forte resistência por parte dos povos indígenas ao ensino universitário, bem como a todo o processo de escolarização, justamente por compreendê-lo como estratégia para promover a aceleração do processo de integração dos povos indígenas. A interligação direta entre as autoridades coloniais sanguinárias e os espaços acadêmicos se consolidou no imaginário dos povos indígenas, espaços esses que seriam lócus de articulação e organização de estratégias de dominação cultural, militar e econômica (LUCIANO, 2009).

Qualquer semelhança com os tempos atuais não deve ser entendida como mera coincidência, e sim como fruto histórico que se enraizou, cristalizou e se mantém até hoje como estratégia do Estado para controle das massas e silenciamento dos povos. De acordo com Silva e Marques (2016), como ganhos do processo sócio histórico supracitado, tem-se a intensificação do protagonismo indígena na luta pela educação diferenciada e por condições dignas de vida, ou basicamente pelos direitos de cidadania.

\begin{abstract}
Os sistemas de educação às populações indígenas devem respeitar e incorporar a comunidade local, oferecendo a atenção diferenciada, prevista na Lei, pós constituição Federal/1988. A lei de Diretrizes e Bases da Educação Nacional e o Plano Nacional de Educação têm abordado o direito dos povos indígenas a uma educação diferenciada. Tal direito está pautado pelo uso e manutenção das línguas indígenas, levando em consideração a valorização dos conhecimentos e dos saberes tradicionais dos povos (GARLET, GUIMARÃES e BELLINI, 2010, p. 66).
\end{abstract}

$\mathrm{Na}$ educação escolar indígena algumas medidas foram construídas e executadas, a fim de efetivar a política pública para o campo, como por exemplo: a contratação de professores bilíngues para atuação nas escolas, a inserção de alimentos tradicionais indígenas na merenda escolar, e a própria presença de indígenas nas universidades, constituem avanços importantes. Porém, no campo 
dos desafios se apresenta a necessidade de adequação das ações pedagógicas (projetos pedagógicos, referencial curricular e planos de ensino) e dos serviços de educação à diversidade cultural e organização dos povos indígenas (GARLET, GUIMARÃES e BELLINI, 2010).

\begin{abstract}
Por exemplo, se na educação básica existe a necessidade de professores bilíngues, como a universidade irá respeitar estas diferenças? Ou tudo irá para o mesmo valão conceitual de um modelo de educação ditado pela cultura branca? É do interesse da política pública que alunos e docentes aprendam a conviver e conhecer a cultura indígena? Que exista uma troca de conhecimento, ou uma mera transmissão de conteúdo dos brancos para os indígenas? (GARLET, GUIMARÃES e BELLINI, 2010. p. 66).
\end{abstract}

Ao se tratar de uma política diferenciada de educação no ensino superior para os povos indígenas, Garlet, Guimarães e Bellini (2010) apontam avanço no campo da inclusão de indígenas em universidades, por meio das cotas. Algumas iniciativas individuais de estados brasileiros se encontram descritas na literatura, como é o exemplo do estado do Paraná, que no ano de 2001, destinou em lei estadual, vagas suplementares nas universidades e faculdades estaduais aos povos indígenas, sendo citada por Amaral e Baibich-Faria (2012) como iniciativa pioneira no Brasil, tendo seu aperfeiçoamento realizado ao longo dos anos.

$\mathrm{Na}$ legislação nacional, as cotas em universidades federais se tornaram realidade com a Lei $\mathrm{n}^{0}$ 12.711, de 29 de agosto de 2012, regulamentada pelo Decreto $\mathrm{n}^{\circ} \mathbf{7 . 8 2 4}$, de 11 de outubro de 2012, quando vagas exclusivas para pretos, pardos e indígenas foram incluídas (BRASIL, 2012). Sendo assim, mesmo que a política de cotas aponte para uma perspectiva de interferência no ciclo de desigualdade no acesso à oportunidades que envolvem os povos indígenas e o povo negro no campo da educação no Brasil, ainda não é suficiente para equacionar as iniquidades no que tange a educação desses grupos étnicos.

Galet, Guimarães e Bellini (2010. p.69), refletindo sobre as cotas afirmam que elas refletem as desigualdades sociais existentes no Brasil entre as raças e as etnias. Questionam a classificação da maioria como minoria, empregando tal fato ao processo sócio histórico decorrente da colonização brasileira, e que atualmente mascara que a minoria que ocupa o ensino superior público é na verdade aquela detentora do poder econômico. "Será que o acesso às universidades continua sendo para os "brancos", ou seja, as "minorias que detêm as "maiores" rendas deste país?"

Nesse contexto se apresentam as ações afirmativas, que segundo a Organização Internacional do Trabalho (OIT) tem por objetivo acelerar o ritmo de 
participação dos membros de grupos sub-representados no acesso ao emprego, educação, treinamento e promoção, por meio de tratamento diferenciado. Cita ainda que a convenção internacional para eliminação de todas as formas de discriminação prevê medidas em favor de alguns indivíduos ou grupos étnicos e raciais, a fim de assegurar o gozo igualitário dos direitos humanos e das liberdades fundamentais (TOMEI, 2005), esbarrando mais uma vez no debate sobre a garantia da cidadania para os povos indígena, apontado no capítulo anterior "índio cidadão?".

No Brasil, a temática das medidas de ações afirmativas para a inclusão de indígenas e negros no ensino superior têm sido bastante explorada, porém com desproporção no que tange a população-alvo dos estudos. Garlet, Guimarães e Bellini (2010), ressaltam que a literatura tem enfatizado o acesso de negros e afrodescendentes às universidades, restando para os povos indígenas menor visibilidade e mais preconceito. Porém, mesmo nesse contexto de desproporção na produção de conhecimento, encontram-se escritas importantes sobre os indígenas no ensino superior, relatando desde experiências até aspectos mais teóricoconceituais, como exposto por Luciano (2009), Amaral e Baibich-Faria (2012), Lima (2012), Garlet, Guimarães e Bellini (2010), Silva e Marques (2016), dentre outros.

Experiências iniciais com a inserção de indígenas no ensino superior, mesmo antes da lei de cotas, apontaram que o conhecimento acadêmico produzido pelos estudantes e pesquisadores (as) indígenas passou a ser estratégico para a afirmação cultural e política dos seus grupos étnicos, assim como para o desenvolvimento das suas comunidades. É importante destacar a complexidade que envolve a permanência de indígenas em universidades urbanas, visto que estes sujeitos experenciam e intercambiam diferentes perspectivas e concepções, trazendo com isso a reflexão sobre sua própria identidade étnica, exercitando o que Amaral e Baibich-Faria (2012) chamam de "dupla pertença", que os caracteriza ao mesmo tempo como indígenas e estudantes universitários.

Que os indígenas adentraram a universidade já é sabido e citado por diversos autores (AMARAL e BAIBICH-FARIA, 2012; LIMA, 2012; RODRIGUES, NOVAK e FAUSTINO, 2014), porém, para além da constatação da existência de indígenas no ensino superior no Brasil outros elementos críticos de importância surgem na construção desse debate, como por exemplo o tipo de universidade existente no Brasil e como essas instituições se colocam disponíveis e dispostas para construir outro tipo de educação, centrada no multiculturalismo e na interculturalidade. 
Lima (2012) denuncia a incapacidade da escola (universidade) de se contrapor a onda permanente de preconceitos cristalizados no senso comum e propagados pela mídia acerca dos indígenas brasileiros. E o seu contínuo desinteresse e desinformação sobre o que ocorreu e sobre o que ainda acontece na história dos povos indígenas nos limites internos e externos do país, do Estado nacional.

Amaral e Baibich-Faria (2012), apontam que a presença de indígenas evidencia a manifestação das contradições, incoerências e paradoxos que constituem a universidade. Os autores evidenciam que os conhecimentos técnicos, científicos e acadêmicos buscados e apreendidos no ensino superior se tornam o cerne da existência da universidade no Brasil, porém, o movimento que garantiria a troca de saberes com os estudantes indígenas raramente acontece. Para os autores, "os indígenas parecem, para a academia, não ter nada sabido ou a ensinar. Ciência e cultura são, nesse paradigma predominante, ainda que não explicitado, patrimônio da universidade e somente dela" (AMARAL e BAIBICH-FARIA, 2012, p. 826).

Se torna portanto difícil justificar respeito e valorização dos saberes tradicionais diante da universidade, já que a mesma só reconhece e admite como verdadeiro os conhecimentos produzidos sob os dogmas e métodos científicos da própria universidade, dando origem a negação dos conhecimentos tradicionais indígenas. O que por sua vez gera um profundo conflito entre os estudantes indígenas, ao se depararem com a perspectiva individualista e cumulativista da academia, que contrasta com a perspectiva comunitarista e solidária da cultura indígena (LUCIANO, 2009).

Esse conflito ético afeta tanto os comportamentos e atitudes quanto as escolhas dos estudantes indígenas universitários, que se veem tendo que escolher entre a preservação da sua cultura, por meio da utilização dos conhecimentos da ciência (não-indígena) à serviço do seu povo, e a utilização desses conhecimentos em proveito pessoal, contrapondo-se à sua essência étnica, que não reconhece espaço para acúmulo de riquezas e poder individuais, apenas a sua partilha e socialização por lealdade ao grupo (LUCIANO, 2009).

A negação dos saberes tradicionais indígenas pela e na universidade gera um mal-estar difícil de administrar para os universitários indígenas, bem como o conflito de lealdade citado anteriormente. Essas tensões, reais e fortes, revelam conflito de 
interesses, envolvendo de um lado aqueles de cunho acadêmico e profissional do sujeito que está na formação universitária e de outro aqueles provenientes das comunidades de origem, com suas perspectivas, interesses e demandas próprias (LUCIANO, 2009).

Ofertar aos estudantes indígenas apenas à lógica de formação dos nãoindígenas, sem garantir a mínima troca entre o saber científico e o saber tradicional indígena, representa um importante fator dificultador da permanência dos indígenas nas universidades brasileiras. Amaral e Baibich-Faria (2012) apontam alguns fatores que condicionam a permanência dos indígenas nas universidades brasileiras, como: o desempenho do estudante no curso, o nível de preconceito social e institucional que sofre, o relacionamento com os colegas e com os professores não-indígenas, as condições financeiras, dentre outros.

Silva e Marques (2016) acrescentam as mudanças pedagógicas trazidas pelo ensino não - indígena, mudanças psicológicas, físicas e emocionais sofridas pelos estudantes indígenas, fruto do distanciamento da família, da jornada intensa de trabalho e estudo, adoecimento, fraqueza e desânimo, levando a déficit no aprendizado e abandono do curso.

A universidade reflete o eurocentrismo presente na sociedade e os
estudantes negros e indígenas ao entrarem na universidade enfrentam
dificuldades de adaptação, no espaço historicamente homogêneo e
dominado por um único grupo étnico, que atua no sentido de manutenção
da estrutura. Assim, a indiferença e a inferiorização sofridas por esses
estudantes são fatores que afetam a permanência dos acadêmicos de
menor renda que já possuem dificuldades financeiras para se manterem na
universidade, mesmo com as políticas de assistência estudantil, dificultando
a permanência, resultando no trancamento de matrículas, repetências e até
mesmo na evasão, que tem apresentado altos índices (SILVA, MARQUES,
2016. p. 113).

Lima (2012) aponta a ausência de políticas de Estado, aquelas de longo prazo ou de caráter permanente, voltadas para fomentar a educação superior de indígenas e que não existe suporte para o enfrentamento e resolução dos principais entraves encontrados pelos estudantes indígenas nas universidades, a exemplo dos recursos para sua manutenção, os esquemas de acompanhamento à sua formação dentro da universidade, como tutorias, muito menos adaptação dos currículos universitários diante dos problemas e questões que cercam o cotidiano de vida e luta dos povos indígenas.

O contexto que cerca os estudantes indígenas em universidades não indígenas é bastante complexo, tendo como resultado um elevado nível de evasão, 
e consequentemente baixo grau de conclusão dos cursos de graduação, como citaram Amaral e Baibich-Faria (2012). Corroborando com tal contexto e traçando uma crítica ao ensino superior para indígenas no Brasil, Lima (2012), revelou que a reflexão sobre o acesso, a permanência, o sucesso ou o fracasso dos estudantes indígenas ainda é insatisfatória, ou como bem nomeou o autor, ainda é primária.

Segundo Garlet, Guimarães e Bellini (2010), considerando a realidade dos povos indígenas no Brasil, as dificuldades são grandes tanto para o ingresso quanto para a sua permanência e conclusão do curso, propondo assim que as medidas e políticas no campo da educação considerem todos os fatores já conhecidos como entraves da formação dos povos indígenas. Para Torres et al (2004. p. 36 apud GARLET, GUIMARÃES, BELLINI, 2010),

\footnotetext{
A gratuidade do ensino deve compreender não só a ausência de taxas ou mensalidades, mas a garantia de reais condições de estudo, por meio de sistemas e mecanismos que permitam ao aluno condições de alimentação, transporte, moradia e disponibilidade de materiais de estudo.
}

Silva e Marques (2016) contribuem para essa discussão ao constatar que a democratização do acesso à educação superior, com destaque para a ampliação da participação de indígenas e negros, representa a possibilidade de alterar as estruturas rígidas e inflexíveis da universidade, tornando-a mais plural e mais real, mudanças essas que possuem o potencial de auxiliar os acadêmicos em seu êxito, ou seja, no processo de formação.

Porém, a reflexão sobre a democratização do acesso de indígenas às universidades deve estar atrelada à discussão sobre a necessidade de construção de uma nova universidade, o que contribuirá para uma formação mais rica, holística e plural. David, Melo e Malheiro (2013. p. 118) citam a reflexão da liderança indígena Azelene Kaingang, "Não somos nós os únicos que devemos nos preparar para entrar na universidade; ela também tem que se preparar para nos receber e nos entender", apresentando assim o duplo sentido que deve existir na (re)construção da universidade para e com os indígenas.

David, Melo e Malheiro (2013. p. 118) ressaltam que a igualdade no acesso à educação não surgirá simplesmente pelo acesso aos currículos hegemônicos existentes, que "buscam, sutilmente, homogeneizar e pasteurizar as culturas não alinhadas aos centros políticos dominantes", sendo necessário a partir da abertura da universidade para a diversidade etnocultural brasileira, o repensar da academia, rumo à construção de currículos multiculturais. 
O multiculturalismo, por sua vez, prega a coexistência enriquecedora de diversos pontos de vista e atitudes, provenientes de diferentes heranças culturais. Seu conceito pressupõe uma posição aberta e flexível, baseada no respeito dessa diversidade e na rejeição a todo preconceito ou hierarquia. Em outras palavras, multiculturalismo, ou pluralidade, passa pelo diálogo entre os diferentes grupos sociais e culturais; passa pelo reconhecimento do outro, incluindo seus saberes e valores (DAVID, MELO, MALHEIRO, 2013. p. 118).

Nesse campo de estímulo ao multiculturalismo nas universidades, existem três riscos que podem contribuir para a perpetuação das desigualdades raciais e preconceitos que nessa construção se deseja combater: o multiculturalismo reparador, o folclorismo e o reducionismo identitário. O primeiro se reduz às ações afirmativas, que apesar de promover o acesso à universidade não contempla transformações curriculares concretas. O segundo se constitui a partir do festejo à diversidade enquanto elemento folclórico e exótico, bem representada pelo dia do índio. E o terceiro acontece quando a identidade étnica é ligada aos estereótipos construídos socialmente, como por exemplo, a ideia de que todo índio é igual, protetor da floresta, preguiçoso ou violento (DAVID, MELO, MALHEIRO, 2013).

A urgência é superar o ideal de tolerância do outro, buscando a construção de ideais democráticos de liberdade e respeito no ensino superior brasileiro (DAVID, MELO, MALHEIRO, 2013). Luciano (2009) também defende a necessidade de transformação dos centros acadêmicos, construindo espaços de diálogos interculturais, não apenas interdisciplinares ou interideológicos. Aponta que espaços multiculturais ou pluriculturais possuem a potencialidade de abrir caminho para que os saberes tradicionais dos povos indígenas e de outros grupos étnico, raciais e sociais, constituam as linhas programáticas dos cursos e programas de formação.

As reflexões apresentadas nesse capítulo se estendem à toda formação no ensino superior, o que inclui a formação de indígenas na área da saúde, que além de englobar todos estes fatores que envolvem o ser indígena numa universidade eurocêntrica associa-se à própria complexidade da formação para atuação no setor saúde. Haddad et al (2010), apontam que entre os diversos fatores que alteram as necessidades na formação em saúde no Brasil estão: as constantes modificações demográficas e epidemiológicas da população e as noções de saúde utilizadas pelo sistema de saúde e pela universidade, tendo a hegemonia centrada na lógica biologicista. 
Haddad et al (2010), ressaltam a necessidade dos cursos da saúde alterarem seus currículos, acrescentando o arcabouço teórico do SUS, a ética, a cidadania, a epidemiologia e o processo saúde/doença/cuidado, buscando a formação de nível superior de qualidade, como apontado internacionalmente. De maneira igualmente importante, a formação em saúde deve prover a conexão com a realidade social, política e cultural, a fim de garantir o respeito aos diferentes significados dos fenômenos humanos, a realidade sanitária e a diversidade regional brasileira.

Sendo assim, a pluralidade etnocultural do Brasil já aponta a urgência de uma formação em saúde para atuação em contexto Interétnico, o que se encontra com as defesas por uma educação superior multicultural e não somente interdisciplinar, como apontado por Luciano (2009) e David, Melo e Malheiro (2013). Segundo Diehl e Pellegrini (2014. p. 871),

\begin{abstract}
A formação em nível de graduação está longe de contribuir para atuação em contextos interétnicos e interculturais. As Diretrizes Curriculares Nacionais falam genericamente de formação humanista, não priorizando aspectos que envolvem a diversidade étnica, o que resulta em não preparação para $\circ$ trabalho com os povos indígenas. Experiências de inserção precoce de estudantes em Terras Indígenas são raras, a exemplo do Projeto Xingu citado anteriormente; o Pró-Saúde e o PET-Saúde, salvo melhor juízo, não têm incluída em seus projetos a saúde indígena. Reflexo disso é o despreparo para lidar com especificidades que vão para além das questões que dizem respeito à recuperação estrito senso da saúde, como por exemplo, organizações sociais e culturais que implicam práticas e saberes próprios de cuidados (envolvendo alimentação, higiene, recursos terapêuticos etc.) com o corpo individual e coletivo.
\end{abstract}

Os autores interrogam sobre a adequação ética e cultural das práticas sanitárias ocidentais para atuação em comunidades indígenas, considerando que os povos indígenas possuem seus próprios sistemas de saúde. A interrogação é feita no sentido que apontar a potencialidade de concepção e organização de um serviço de saúde mais amplo (DIEHL, PELEGRINI, 2014), o que influencia tanto na produção do serviço quanto na formação de profissionais de saúde, é claro se a formação estiver alinhada e conectada com a realidade do sistema de saúde.

Assim, o estudante indígena tem, de um lado, a crise advinda do descompasso entre o reconhecimento da ciência ocidental como verdade absoluta e a negação do conhecimento tradicional pela universidade (AMARAL, BAIBICHFARIA, 2012; LUCIANO, 2009), e de outro, o conhecimento próximo das riquezas, problemas e particularidades que envolvem o seu grupo étnico, conhecimento esse que é negado e anulado, porém que possui grande potencialidade para enriquecer e ampliar o olhar sobre a saúde, principalmente a dos povos indígenas. 
Dessa forma cabe a reflexão: Como garantir a formação qualificada de profissionais indígenas de saúde para atuação junto ao seu grupo étnico diante de uma universidade centrada no saber não-indígena e que nega a riqueza dos estudantes indígenas, que se reflete nos saberes tradicionais ancestrais?

Segundo Gersem Baniwá, a formação universitária de indígenas possui alguns objetivos claros, que são:

O primeiro - instrumentalizar os indígenas com os conhecimentos técnicos e
científicos para nivelar as relações de diálogo e de negociação de seus
direitos; O segundo - possibilitar acesso e apropriação adequada de
conhecimentos técnico-científicos necessários para melhorar as condições
de vida das comunidades; O terceiro - instrumentalizar os indígenas de
conhecimentos técnicos e tecnológicos que os auxiliem na gestão adequada
e qualificada de seus territórios e de seus recursos naturais. Por fim, a
universidade é vista como espaço instrumental para aperfeiçoar, enriquecer
e complementar os conhecimentos e saberes tradicionais (LUCIANO, 2009,
p. 33).

Portanto, nota-se claramente, a partir das pontuações realizada por Luciano (2009) que o saber técnico-científico representa a complementação dos saberes tradicionais ancestrais dos alunos indígenas, sendo este o centro orientador das práticas como estudantes e posteriormente como profissionais de saúde, destacando assim o óbvio, que estudantes e profissionais de saúde indígenas não deixam de ser indígenas por ocuparem outros espaços e por adquirirem novos conhecimentos.

Vale destacar nesse contexto a importância de discutir sobre a educação superior em saúde interligada às necessidades dos povos indígenas e às possibilidades de captação da força de trabalho indígena formada, ao mercado de trabalho em saúde no Brasil. Não refletir sobre os indígenas no mercado de trabalho em saúde é antes de tudo negar a existência de indígenas como profissionais de saúde, perpetuar as iniquidades raciais no mercado de trabalho e anular todos os esforços para ampliação da participação dos indígenas no ensino superior e consequentemente na força de trabalho em saúde. Ou será que o Brasil forma indígenas para ficar na vitrine e não para compor a Força de Trabalho em Saúde?

\subsection{FORÇA DE TRABALHO EM SAÚDE: ONDE SE ENCAIXAM OS INDÍGENAS?}


Como início da reflexão proposta nesse capítulo, torna-se fundamental contextualizar alguns conceitos, como o de Força de Trabalho e de Força de Trabalho em Saúde.

O termo força de trabalho foi consagado no campo da economia política, estando principalmente ligado ao Filósofo Adam Smith, ao Economista David Ricardo e ao Filósofo, Soliólogo e Jornalista Karl Marx (NOGUEIRA, 1983). Desses, Karl Marx teve grande destaque, tendo o conceito FT o reconhecimento como uma das grandes contribuições de Marx para a economia política (VIEIRA, 2012).

Assim, a FT fundamentada no pensamento de Karl Marx, remete ao potencial para o trabalho que o indivíduo vende ao capitalista para ser utilizado na produção (MARX, 1984). Se relaciona com a individualidade do homem (trabalhador (a)), estando o seu uso limitado às suas energias ativas e à sua força fisica, tendo o seu valor definido pela quantidade de trabalho necessária à produção. Marx diz ainda que,

\begin{abstract}
Na base do sistema de salários, o valor da força de trabalho é estabelecido como o de outra mercadoria e, como diferentes espécies de força de trabalho têm diferentes valores ou requerem diferentes quantidades de trabalho para a sua produção, tem de alcançar diferentes preços no mercado de trabalho (MARX, 1984. Pag. 51).
\end{abstract}

Marx evidencia que no capitalismo o ser humano passa a ser uma mercadoria, sendo assim, todo trabalho teria um preço, o que se estende consequentemente aos homens que o produzem. Dessa forma, o trabalho seria um produto indireto dessa relação e a força de trabalho o produto direto alvo da venda ao detentor do capital, o comprador. "O operário vende não é diretamente o seu trabalho, mas a sua força de trabalho". O uso ou emprego da força de trabalho constitui o próprio trabalho, que possui por sua vez três elementos importantes: a atividade pessoal do homem, o objeto em que se exerce o trabalho e o meio pelo qual se exerce (MARX, 1984, p. 49).

Vale destacar que o conceito de FT trazido por Marx é foco de polêmicas e contraposições, como apontadas por Vieira (2012) e Moore (2010), sendo fundamental destacá-las como forma de ampliar a visão crítica sobre o tema, apoiando a discussão sobre força de trabalho brasileira em saúde. Além de evidenciar importância de não compreender os conceitos como verdades absolutas, e sim como produtos que dizem muito sobre quem o elaborou, suas experiências, visões de mundo e contexto sociopolítico em que se inserem. 
Pedro Antônio Vieira, Doutor em Economia pela Universidad Nacional Autónoma de México, discorda da racionalidade econômica que aponta o trabalho (na economia clássica) ou a força de trabalho (Marx) como uma mercadoria como outra qualquer. Vieira (2012) embasado nas contribuições de Karl Polanyi, expõe a crítica à pretensão de subordinar toda a vida social ao mercado, se recusando à enxergar os processos de vida pela lente do mercado. Nessa tentativa de compreender o trabalho como natural do ser humano, parte dos individuos, Polanyi destacou que:

O trabalho é apenas um outro nome para a atividade humana que acompanha a própria vida, que por sua vez, não é apenas produzida para a venda, mas por razões inteiramente diversas, e essa atividade não pode ser destacada do resto da vida, não pode ser armazenada ou mobilizada [...] sua descrição como mercadoria é inteiramente fictícia (POLANYI, 2000 apud VIEIRA, 2012, p.194).

Atrelada à contraposição exposta por Polanyi, Himmelweit (2001 apud VIEIRA, 2012. p. 198), reforça a crítica à Karl Marx,

Mas [Marx] nunca se empenhou em desenvolver uma análise completa dos
problemas colocados pela determinação do valor da força de trabalho em
vista de sua natureza excepcional enquanto mercadoria. A força de trabalho
é produzida, se produzida for a palavra, fora da produção capitalista, por
uma unidade constituída por outros além daqueles que a vendem. Difere,
portanto, de qualquer outra mercadoria, se mercadoria for a palavra, pelo
fato de que seu valor de troca não é o único objetivo de seus produtores, se
é que estes têm um objetivo.

As leituras de Polanyi (2000) e Himmelweit (2001) apontadas por Vieira (2012) evidenciam que nem todo ser humano estará submetido à lógica do mercado, do capital, ou seja, nem todo indíviduo trabalhará com o intuito de vender sua força de trabalho para produzir dinheiro. Essa visão contra-hegemônica traz contribuição importante para a consideração da diversidade de realidades e composições culturais existentes no trabalho no Brasil. Sendo assim, considerando que diversas culturas distintas existem e coexistem no país e consequentemente nos ambientes de trabalho, as lógicas que cercam o trabalho, de fato, também podem ser diversas e dissonantes da lógica do capital, como apontam os autores.

Assim também, as pontuações de Carlos Moore, homem negro, etnólogo, pesquisador Cubano e referência internacional na luta contra a opressão racial, contibribuem para compreender em que bases esses conceitos apontados por Marx foram criados, interferindo nas concepções sobre trabalho em todo mundo. Segundo Moore (2010, p. 61),

[...] a sociedade ocidental e os povos europeus, exclusivamente, teriam 
fornecido o modelo histórico e o protótipo social para as generalizações mais importantes de Marx a respeito de todas as sociedades humanas [...] existem fortes indicios de que isso se deu devido [...] à orientação profundamente eurocêntrica de Marx [...] A supremacia branca colocara, assim, o mundo sob seu domínio econômico, político e cultural racista.

Moore (2010) chama atenção para as defesas pró-escravidão e prócolonização realizadas por Marx, especialmente em sua obra "a miséria da filosofia" (1846-47), que segundo o autor, revela as opiniões de Marx sobre a escravidão nas Américas,

\begin{abstract}
"A escravidão é uma categoria econômica como qualquer outra. Portanto, possui também seus dois lados. Deixemos o lado mau e falemos do lado bom da escravidão, esclarecendo que se trata da escravidão direta, a dos negros no Suriname, no Brasil, nas regiões meridionais da América do Norte [...] A escravidão direta é o eixo da indústria burguesa, assim como as máquinas, o crédito, etc. Sem a escravidão não teríamos o algodão, não teríamos a indústria moderna [...] Sem a escravidão, a América do Norte, o país progressista, transformar-se-ia num país patriarcal (tribal)[...] suprimase a escravidão e ter-se-á apagado a América do Norte do mapa das nações" (MOORE, 2010. p. 89).
\end{abstract}

Torna-se nítido que as pontuações trazidas por Marx extrapolam as constatações do que se apresentava na época, revelando a escravidão como algo extremamente naturalizado, já que não se tratava da escravidão dos brancos, e sim de negros, como destaca Marx. Sendo assim, seus conceitos são carregados, consequentemente, de sua visão eurocêntrica sustentadora da supremacia branca, apoiando desta forma a evidenciação de que os conceitos referentes à força de trabalho não deveriam ser universais, já que podem não se referir à todos os indíviduos e grupos socioraciais.

Feitas todas essas ressalvas com o intuito de contribuir para a compreensão ampliada e contextualizada do conceito de força de trabalho, vale destacar que o termo é reconhecido e utilizado internacionalmente nos debates e produções sobre o trabalho, o que inclui o seu uso cotidiano no Brasil. No campo da saúde, o conceito de FT é bastante usual, porém algumas adaptações surgiram na tentativa de conectar o conceito à complexidade do setor saúde, como é o caso do proposto por Paim (1994. p.64), que aponta a Força de Trabalho em Saúde da seguinte maneira,

[com] a compreensão dos Recursos Humanos como Força de Trabalho na sua dupla dimensão - 'mercadoria' específica e ator social capaz de fazer história - além de 'sujeito-agente' das práticas de saúde, eticamente comprometido com a vida e com a redução do sofrimento humano, implica a superação da ideia de meros insumos da função de produção. Já não bastam os enfoques da administração, do planejamento normativo, de teoria do capital humano. 
Paim (1994) pontua também outros significados para força de trabalho em saúde usualmente utilizados no campo, como por exemplo, pessoal de saúde, categorias profissionais, agentes, trabalhadores de saúde, recursos humanos, profissional de saúde, etc. Vale destacar que o termo recursos humanos, apesar de muito recorrente possui lógica de concepção distinta do que foi exposto para a FT. Segundo Nogueira (1983), o termo RH advém da administração e por isso concebe o trabalhador, ou sua capacidade de trabalho, como um recurso capaz de ser gerenciável. Vale o destaque de que o uso do termo $\mathrm{RH}$ na saúde pode gerar certo reducionismo e simplificação da atuação dos (as) trabalhadores (as)/profissionais de saúde e da própria complexidade do trabalho em saúde, merecendo atenção em sua aplicação.

Dentro desse debate de conceitos e nomenclaturas, a Secretaria de Gestão do trabalho e da Educação na Saúde (SGTES) do Ministério da Saúde aponta dois conceitos importantes, o de profissão e de profissional de saúde. Sendo assim, uma profissão é definida como ocupação que exige conhecimentos e habilidades especializadas por parte de quem a executa. E o profissional de saúde, um indivíduo que possui formação profissional específica ou qualificação prática ou acadêmica para desenvolver atividades ligadas ao cuidado ou às ações de saúde (BRASIL, 2013), como é o caso das atividades desenvolvidas na assistência à saúde.

No campo da saúde, as atividades de assistência integram o conjunto dos chamados serviços de consumo coletivo, os quais, por conta das mudanças na estrutura global da sociedade, fazem dos serviços de saúde - principalmente das mercadorias que são produzidas e veiculadas por eles - um dos itens mais importantes empregados na manutenção e ampliação da escala de produção capitalista. Sendo assim, a assistência a saúde possui a característica de incorporar proporções crescentes de FT (NOGUEIRA, 1983).

Segundo Machado e Oliveira (2006), o setor saúde, mesmo em momentos de crise tem se comportado de forma interdependente de outras políticas setoriais de emprego, já que mantém o dinamismo do sistema de produção de serviços e a elevação de sua força de trabalho. Koster e Machado (2012) apontam que o mercado de trabalho em saúde recebe anualmente 40 mil profissionais, entre médicos, enfermeiros, dentistas, farmacêuticos, nutricionistas e fisioterapeutas. No ano de 2005 havia 2.566.694 postos de trabalho, distribuídos majoritariamente na esfera pública $(56,4 \%)$ e privada $(43,6 \%)$, representando $11 \%$ do quantitativo total de 
empregos formais no Brasil. Esses dados revelam claramente que o maior empregador no mercado de trabalho em saúde é o SUS.

O SUS é um sistema público de prestação de serviços de saúde para a
população brasileira, que compreende atividades dirigidas a pessoas e
coletividades, desenvolvidas no âmbito federal, estadual e municipal. As
ações do SUS são voltadas para a promoção da saúde, prevenção e
tratamento de doenças, além de intervenções sobre o ambiente onde se
vive e trabalha. Suas atribuições prevêem ainda o controle de qualidade e o
desenvolvimento de pesquisa e produção de medicamentos, equipamentos
e outros insumos necessários à realização das ações sanitárias no país
(NORONHA, LIMA, MACHADO, 2008)

A compreensão das particularidades do trabalho em saúde é citada por Nogueira (1983) como relevante na avaliação da FTS. São exemplos: o acentuado dinamismo e inovações tecnológicas, a introdução de novos serviços, a ação combinada entre vários profissionais e a aplicação das forças produtivas das ciências e tecnologias para elevar a produtividade. Machado e Oliveira (2006) acrescentam a estas a inserção singular do setor saúde no sistema econômico brasileiro, refletida pela "alta repercussão e incontestável relevância social dos serviços prestados à sociedade" (MACHADO, OLIVEIRA, 2006. p.59) e a capacidade do setor saúde amortecer o impacto social do desemprego em grandes centros urbanos, já que incorpora a FT excedente no mercado. Merece destaque a sua ligação direta com a vida humana, sendo talvez, a mais importante das especificidades do trabalho em saúde.

Sendo assim, conhecer essas e outras especificidades, bem como as diversas concepções que cercam o trabalho e a força de trabalho em saúde é fundamental para a gestão eficiente do trabalho na saúde e no SUS. Segundo o Ministério da Saúde (MS), a gestão do trabalho no SUS é:

Política que trata das relações de trabalho, a partir de uma concepção na
qual a participação do trabalhador é fundamental para a efetividade e
eficiência do sistema único de saúde. [...] o trabalhador é percebido como
sujeito e agente transformador de seu ambiente e não apenas um mero
recurso humano realizador de tarefas previamente estabelecidas pela
administração local. [...] E o trabalho é visto como um processo de trocas,
de criatividade, coparticipação e corresponsabilização, de enriquecimento e
comprometimentos mútuos (BRASIL, 2012, p. 23).

Desta forma, enquanto política, todos os pontos expostos nesse capítulo se ligam intrinsecamente à gestão do trabalho na saúde e no SUS. Principalmente, por que a força de trabalho em saúde tem sido apontada, por décadas, como um dos importantes nós críticos do SUS, desde a promulgação da Lei Orgânica da Saúde. Porém, apesar desse reconhecimento, percebe-se atenção incompatível com a 
necessidade, no que se refere à organização e gestão em nível nacional (PEREIRA, 2004).

Fortalecer a gestão do trabalho na saúde é fundamental para a qualificação do sistema de saúde, bem como para o enfrentamento da crise da FTS. Muito tem se falado sobre a crise global da FTS, que se caracteriza por déficit global de mais de 4 milhões de profissionais de saúde, além de desigualdades na distribuição e acesso dessa FT. O Brasil não foge à regra, pois apresenta déficit de pessoal, principalmente em regiões rurais, periferias urbanas e locais de dificil acesso (DAL POZ, 2013), como por exemplo as áreas indígenas. Vislumbra-se o agravamento desta crise nos próximos anos, pois a demanda por profissionais de saúde cresce marcadamente, acompanhando as mudanças epidemiológicas e sociodemográficas.

Associado e compondo a crise da FTS, há ainda as iniquidades entre mulheres e homens, indígenas, negros, brancos, e amarelos, o que gera acentuada assimetria no mercado de trabalho em saúde no Brasil. Laís Abramo (2006) reforça a desigualdade de gênero e raça como eixo estruturante da matriz da desigualdade social no Brasil, auxiliando na reprodução e manutenção das situações de exclusão social. E, em se tratando de exclusão social e mercado de trabalho, Chadarevian (2011) chama atenção para a permanência do elevado grau de desigualdade racial no mercado de trabalho no Brasil, sendo assim suficiente para perceber a existência do racismo,

[...] definido como o processo que determina a hierarquização racial em uma economia, por meio da atuação de mecanismos de discriminação, como a divisão racial do trabalho ou a discriminação salarial exercidas contra a população não branca (CHADAREVIAN, 2011. p. 292)

Chadarevian (2011) sugere a elaboração de um indicador alternativo da desigualdade racial com foco na estrutura ocupacional do mercado de trabalho. $O$ objetivo seria evidenciar o grau de hierarquização racial da força de trabalho, por meio da identificação da composição racial da elite ocupacional. Assim sendo, quanto maior for a discrepância entre brancos e não-brancos nas ocupações-chave da vida profissional maior será o quadro de hierarquização racial. Ressalta que "a ausência de não-brancos em cargos de direção e de altos salários é sempre apontada como um dos sinais mais evidentes da existência de discriminação e racismo em uma sociedade" (CHADAREVIAN, 2011. p. 292).

A contribuição de Chadarevian chama atenção para a necessidade de 
analisar a força de trabalho não apenas quantitativamente, incluindo aspectos que dizem respeito à sua composição. No campo da saúde isso se faz urgente, visto que o SUS possui como princípio a equidade e está calcado na justiça social. De acordo com Nogueira (1987), a força de trabalho em saúde não pode ser limitada à uma descrição de números e usos, mas deve ser foco de avaliação qualificada, com especial atenção à avaliação dos aspectos referentes à geração de empregos, captação de pessoal recém-formado e, dos aspectos referentes à dimensão, distribuição, composição interna e utilização da $\mathrm{FT}$, de forma que corresponda as linhas e diretrizes da política nacional de saúde.

Nogueira (1987) expõe ainda alguns questionamentos importantes sobre a temática: Será que o crescimento da FTS irá responder às forças de mercado ou terá um mínimo de racionalidade, tendo como base critérios de justiça social? Esse crescimento cumprirá os requisitos da equidade e universalidade que norteiam a política de saúde no país? Essas pontuações realizadas por Nogueira acrescentam relevantes elementos ao debate, principalmente no que tange a urgência de realizar levantamentos qualificados sobre a composição racial da força de trabalho em saúde, buscando aprofundar os conhecimentos sobre as disparidades e as desigualdades raciais presentes no mercado de trabalho em saúde no Brasil.

É curioso como a pauta das desigualdades de raça no trabalho aparecem na literatura científica e institucional restrita as análises entre brancos e negros (ABRAMO, 2006; HERINGER, 2002; BRASIL, 2011; TOMEI, 2005), ou quando citam não - brancos, restringem a negros e mestiços (CHADAREVIAN, 2011), mantendo ainda a invisibilização dos indígenas nas produções e consequentemente nos debates sobre desigualdades raciais no mercado de trabalho, o que inclui o da saúde. As produções aparecem indicando diferenciais no quantitativo de brancos e negros no mercado de trabalho, de remuneração, de jornada de trabalho, de exposição a situações de violência, etc.

Um exemplo disso são as produções sobre as desigualdades raciais e de gênero elaboradas pelo Instituto de Pesquisa Econômica Aplicada (IPEA), fundação vinculada ao Ministério do Planejamento, Desenvolvimento e Gestão, que tem por objetivo fornecer suporte técnico-institucional para o governo, destinado à formulação e reformulação de políticas públicas (BRASIL, 2016). Considerando a importância estratégica do IPEA no fornecimento de dados e informações que subsidiem a tomada de decisão governamental é, no mínimo, preocupante, para não 
dizer alarmante, que a fundação realize análises sobre as desigualdades raciais de maneira tão excludente, invisibilizando os indígenas, o que consequentemente poderá reverberar na invisibilidade dos indígenas nas políticas públicas de combate à desigualdade racial no mercado de trabalho.

As quatro edições da publicação oficial do IPEA denominada retratos das desigualdades de gênero e raça, abordam as desigualdades entre brancos e negros, em diversos campos da vida, como saúde e emprego (BRASIL, 2004; BRASIL, 2006; BRASIL, 2008; BRASIL, 2011). Em todas as análises de todas as edições os indígenas não foram sequer citados, restando para os mesmos apenas a invisibilidade. $O$ intrigante é perceber que mesmo o Brasil asssumindo compromissos internacionais para promoção da igualdade racial e combate ao racismo no trabalho, as suas ações governamentais na prática não refletem as intenções firmadas pelo país.

Será que o Brasil não tem indígenas inseridos no mercado de trabalho? Ou será que a invisibilidade já se constitui no próprio racismo empregado contra os povos indígenas? Como afirmar a cidadania plena dos povos indígenas se para o governo brasileiro eles se mantém ignorados, vítimas do racismo e da desigualdade racial no trabalho e em outros campos da vida?

Segundo Laís Abramo (2006), a análise das desigualdades de gênero e raça deve ser considerada nos processos de formulação de políticas públicas em geral. E exatamente por isso que a invisibilidade dos povos indígenas nas produções oficiais de informações sobre as desigualdades raciais no trabalho se constitui em problemática importante. Como os indígenas serão incluídos nas políticas públicas de enfrentamento das discriminações e combate ao racismo se não são reconhecidos como sujeitos vítimas de tais processos?

Nesse âmbito das respostas do Estado voltadas ao enfrentamento das desigualdades raciais se encontram as ações afirmativas. De acordo com Silva (2006), as ações afirmativas se caracterizam como um conjunto de medidas planejadas para promover $\mathrm{o}$ avanço de determinados grupos raciais, étnicos $\mathrm{e}$ socioeconômicos historicamente desfavorecidos. Por meio da impulsão à mobilidade social, tais políticas são uma forma de compensação não só por conta de discriminação sofrida no passado, mas também como reparação de discriminações que ocorrem no presente.

Segundo a OIT, medidas que visam acelerar a velocidade com que membros 
de grupos sub-representados tenham acesso ao emprego, treinamento profissional e promoção são realidade em várias partes do mundo, alterando apenas a nomenclatura utilizada. Por exemplo, equidade no emprego utilizada pelo Canadá e África do Sul, ação positiva utilizada na Europa e ação afirmativa muito recorrente no Brasil (TOMEI, 2005). A Organização afirma ainda que,

A ação afirmativa amplia a noção de igualdade e não discriminação. 0 termo discriminação, de acordo com a Convenção 111 da OIT, relativa à discriminação no emprego e ocupação, uma das mais ratificadas entre todas as convenções da OIT, inclui toda distinção, exclusão ou preferência, com base em raça, cor, sexo, religião, opinião pública, nacionalidade ou origem social, que tenha por efeito anular ou reduzir a igualdade de oportunidade ou de tratamento no emprego ou ocupação (TOMEI, 2005. p. 10).

No campo das intenções voltadas para o combate da discriminação no emprego e ocupação, o que inclui a discriminação racial no trabalho, o Brasil assumiu compromisso com a pauta quando se tornou signatário da Convenção 111 da OIT no ano de 1965, sete anos após a sua elaboração e aprovação (OIT, 2016). A Convenção sobre a discriminação no emprego e profissão, que inclui o acesso à formação profissional, ao emprego, às diferentes profissões e as condições de emprego, aponta responsabilidades dos membros (países) que se tornam signatários desta convenção, o que se aplica ao Brasil (OIT, 1958), como apontadas à seguir:

a) Esforçar-se por obter a colaboração das organizações de empregadores e trabalhadores e de outros organismos apropriados, com o fim de favorecer a aceitação e aplicação desta política; b) promulgar leis e encorajar os programas de educação próprios a assegurar esta aceitação e esta aplicação; c) revogar todas as disposições legislativas e modificar todas as disposições ou práticas administrativas que sejam incompatíveis com a referida política; d) seguir a referida política no que diz respeito a empregos dependentes do controle direto de uma autoridade nacional; e) assegurar a aplicação da referida política nas atividades dos serviços de orientação profissional, formação profissional e colocação dependentes do controle de uma autoridade nacional; f) indicar, nos seus relatórios anuais sobre a aplicação da convenção, as medidas tomadas em conformidade com esta política e os resultados obtidos (OIT, 1958. Art. 3. P. 2).

Soma-se à Convenção 111 a Convenção 169 da OIT, elaborada em 1989 por meio de diálogo internacional e ratificada pelo Brasil no ano de 2002, especificamente 13 anos após a sua elaboração (OIT, 2016). A Convenção 169 da OIT se tornou estratégica para os povos indígenas como instrumento legal de luta por melhores condições de vida e respeito aos direitos garantidos na CF de 88 e consequentemente à própria cidadania (OIT, 1989).

A convenção169, que trata sobre os povos indígenas e tribais, aponta 
recomendações que devem ser seguidas pelos países que a ratificaram, entre elas: a adoção de medidas para reduzir as dificuldades que esses povos experimentam ao enfrentarem novas condições de vida e de trabalho, a priorização da melhoria das condições de vida e trabalho, do nível de saúde e educação desses povos nos planos de desenvolvimento econômico do país, dentre outras (OIT, 1989).

Além das vastas recomendações que visam assegurar a garantia dos direitos de cidadania aos povos indígenas, a Convenção 169 da OIT traz uma seção específica sobre a igualdade de oportunidades e combate à discriminação racial dos povos indígenas no mercado de trabalho (OIT, 1989), o que deveria ser um guia para a formulação de políticas públicas pelo Estado brasileiro. Assim, a Convenção aponta as seguintes medidas acerca da contratação e condições de emprego dos povos indígenas:

Contratação e Condições de Emprego:

1. Os governos deverão adotar, no âmbito da legislação nacional e em cooperação com os povos interessados, medidas especiais para garantir aos trabalhadores pertencentes a esses povos uma proteção eficaz em matéria de contratação e condições de emprego, na medida em que não estejam protegidas eficazmente pela legislação aplicável aos trabalhadores em geral. 2. Os governos deverão fazer o que estiver ao seu alcance para evitar qualquer discriminação entre os trabalhadores pertencentes aos povos interessados e os demais trabalhadores, especialmente quanto a: a) acesso ao emprego, inclusive aos empregos qualificados e às medidas de promoção e ascensão; b) remuneração igual por trabalho de igual valor; c) assistência médica e social, segurança e higiene no trabalho, todos os benefícios da seguridade social e demais benefícios derivados do emprego, bem como habitação; d) direito de associação, direito a se dedicar livremente a todas as atividades sindicais para fins lícitos, e direito a celebrar convênios coletivos com empregadores ou com organizações patronais (OIT, 1989, p. 6).

Acrescenta-se à essas movimentações do governo brasileiro, o compromisso com a promoção do Trabalho Decente no país, por meio de cooperação técnica com a OIT. A parceria gerou a Agenda Nacional do Trabalho Decente (2006), vinculada ao Ministério do Trabalho e Emprego (MTE), como estratégia de ação que tem por objetivo promover o trabalho adequadamente remunerado, exercido em condições de liberdade, equidade e segurança, capaz de garantir uma vida digna aos indivíduos. Possui a promoção da igualdade de oportunidade e tratamento e combate à discriminação como linha de ação estratégia, por meio da implementação de programas e ações de combate à discriminação no trabalho, com atenção à população negra, mulheres, idosos, jovens, pessoas portadoras de HIV/AIDS e 
deficiências (BRASIL, 2006). Apesar de importante estratégia, torna-se evidente a invisibilização dos indígenas nesse campo.

Dessa forma, considerando esse vasto panorama de intenções assumidas pelo Brasil, é válido refletir sobre as práticas executadas pelo Estado brasileiro após 51 anos de ratificação da convenção 111, 14 anos de ratificação da convenção 169 da OIT e 10 anos de criação da ANTD. Quais as políticas, leis, programas, ações ou projetos práticos já foram elaborados e executados pelo governo brasileiro direcionado aos povos indígenas no que diz respeito à ampliação do acesso ao mercado de trabalho, à promoção igualdade de oportunidade, da equidade no emprego e ao combate à discriminação racial? Quais as ações afirmativas existentes para a ampliação do acesso ao mercado de trabalho? Essas ações alcançam os povos indígenas brasileiros?

A resposta a essas perguntas é clara e simples: Não existem ações com tais propósitos. A ação promovida pelo Estado brasileiro, em nível nacional, voltada para a inclusão de indivíduos no mercado de trabalho, tendo como base a questão racial é a Lei no 12.990/2014 que,

Reserva aos negros $20 \%$ (vinte por cento) das vagas oferecidas nos
concursos públicos para provimento de cargos efetivos e empregos públicos
no âmbito da administração pública federal, das autarquias, das fundações
públicas, das empresas públicas e das sociedades de economia mista
controladas pela União (BRASIL, 2014. p. 1).

Diante disso nota-se que, apesar do Estado brasileiro realizar compromissos internacionais e nacionais voltados para o combate da discriminação racial entre indígenas no mercado de trabalho isso ainda permanece no plano dos desejos. A lei supracitada, conhecida popularmente como a lei de cotas em concursos públicos simplesmente ignora os povos indígenas brasileiros, ofertando a eles mais do racismo do Estado, como foi apresentado no capítulo 2.1. O poder de deixar morrer ou deixar viver ainda é exercido pelo Estado brasileiro (FOUCAULT, 2005), que opta por deixar os povos indígenas à margem do acesso aos direitos sociais, como é o caso do trabalho, e consequentemente à margem da própria cidadania. Perpetuar a lógica de exclusão dos povos indígenas no mercado de trabalho é perpetuar a opressão, o racismo e o genocídio contra esses povos.

Assim, frente a essa contradição posta para os indígenas no mundo do trabalho, surge a necessidade de discutir a força de trabalho em saúde à luz dos compromissos assumidos pelo Estado, bem como da sua falta de operacionalização 
para os povos indígenas. Como pode-se utilizar as contradições do Estado para impulsionar mudanças necessárias? Seria realmente prudente e justo manter a lei de cotas em concursos públicos restritas aos negros? Quais outras medidas poderiam ser elaboradas visando a inserção de indígenas no mercado de trabalho? Como os indígenas que estão se formando em graduações da saúde poderão ser captados pelo mercado de trabalho em saúde se as políticas e medidas existentes já os excluem enquanto futuros (as) trabalhadores (as) indígenas?

Essas e outras questões surgem como motivadores de novas buscas e possíveis caminhos para o enfrentamento da exclusão dos indígenas das políticas públicas e das ações governamentais voltadas ao combate da discriminação racial e ampliação da participação de grupos excluídos socialmente no mercado de trabalho.

Vale ressaltar que a literatura não aponta produções que abordem os profissionais indígenas de nível superior inseridos na saúde, como se de fato não existissem profissionais indígenas atuando no setor. Com exceção de uma pesquisa realizada recentemente pela Escola Nacional de Saúde Pública (ENSP) da Fundação Oswaldo Cruz (Fiocruz), executada no ano de 2013 e divulgada em 2016. O estudo intitulado o perfil da Enfermagem no Brasil teve como população-alvo todos os enfermeiros, técnicos e auxiliares de enfermagem do Brasil, que possuíam registro ativo no Conselho Federal de Enfermagem (COFEN). Dentre os achados do estudo foi evidenciado a presença de enfermeiros, auxiliares e técnicos de enfermagem indígenas (MACHADO et al, 2016), apontando com isso, perspectivas positivas para o combate futuro da invisibilidade dos indígenas nos referenciais teóricos sobre a força de trabalho em saúde de nível superior.

Destaque deve ser dado às diversas produções sobre o trabalho do Agente Indígena de Saúde (AIS), (ROCHA, 2007; DIEHL, LANGDON, DIAS-SCOPEL, 2012; PONTES, STAUFFER, GARNELO, 2012; SCOPEL, DIAS-SCOPEL, LANGDON, 2015), que apesar de não possuir formação de nível superior (foco deste trabalho), pode contribuir para o debate sobre a presença de indígenas na assistência à saúde. Esses exemplos podem fornecer pistas e informações acerca dos processos de trabalho, riquezas e entraves vivenciados pelos indígenas no campo do trabalho em saúde.

Portanto, para conseguir traçar uma conexão entre as experiências dos AIS e o contexto que pode estar posto também para trabalhadores (as) indígenas de nível superior é importante considerar, com clareza, que o SUS é o maior empregador do 
setor saúde (KOSTER E MACHADO, 2012) e que os agentes indigenas de saúde estão inseridos no âmbito do subsistema de saúde indígena, subproduto do SUS, responsável pela atenção integral e diferenciada à saúde indígena (GARNELO, 2012).

De acordo com Garnelo (2012), a inclinação do SUS em priorizar ações de saúde no grandes centros urbanos na época de sua criação, o reconhecimento das singularidades presentes no modo de vida dos povos indígenas e a inaptidão do SUS para atender a tais especificidades, levou a criação do Subsistema no ano de 1999, vinculado hierarquicamente ao SUS.

Sendo assim, as experiências relatadas na literatura sobre o (a) trabalhador (a) indígena de saúde, que nesse caso é o (a) agente indígena de saúde, se dá no âmbito desse subsistema, especificamente para cumprir os propósitos da Política Nacional de Atenção à Saúde dos Povos Indígenas (PNASPI), ou seja, garantir aos povos indígenas o acesso à atenção integral à saúde, de acordo com os princípios do SUS. O respeito a diversidade social, cultural, geográfica, histórica e política dos povos indígenas é eixo central da PNASPI, buscando combater a vulnerabilidade aos agravos à saúde, reconhecendo e respeitando a medicina tradicional indígena e sua eficácia (BRASIL, 2002).

Vale destacar que a preparação de recursos humanos para atuação em contexto intercultural é uma diretriz dessa política (BRASIL, 2002), o que evidencia a importância de preparação de profissionais, principalmente não-indígenas, para atuação junto as culturas indígenas, evitando inadequações culturais e profissionais, e possibilitando a efetivação de uma atenção diferenciada para a saúde indígena. Segundo Carvalho, Santos e Campos (2013), o processo de escolha dos (as) trabalhadores (as) para compor a força de trabalho de determinado sistema de saúde deve objetivar o alcance das metas e propósitos da saúde, levando em consideração os conhecimentos, habilidades e competências necessárias para a execução qualificada das políticas de saúde.

E em se tratando de atenção diferenciada, e considerando as pontuações feitas por Carvalho, Santos e Campos (2013), por que não pensar em inserir trabalhadores (as) indígenas como forma de diminuir as distâncias culturais, facilitar os diálogos, valorizar a cultura tradicional e empoderar os (as) indígenas para a continuidade do cuidado à saúde em sua comunidade? Considerando que a PNASPI não evidencia a potencialidade de indígenas para atuarem junto às suas 
comunidades de origem como profissionais de saúde de nível superior, não seria óbvio pensar em indígenas como profissionais de saúde específicos e prioritários do subsistema?

Lhuilier (2013) contribui para a reflexão acima ao afirmar que o trabalho é campo de busca identitária que motiva o sujeito a criar, apresentar e fazer reconhecer suas singularidades através de suas práticas. Sendo assim, as práticas de indígenas como profissionais de saúde do subsistema de saúde indígena poderiam apoiá-los à valorizar sua própria identidade étnica, fortalecer seu povo e sua comunidade de origem? Para saber essa e outras respostas é fundamental que estudos sejam realizados com os (as) profissionais de saúde indígenas e com os usários dos serviços de saúde indígena, a fim de conhecer os encontros e desencontros dessa atuação, para o (a) trabalhador (a), para a comunidade e para o serviço de saúde.

Estudo com profissionais de enfermagem atuantes na saúde indígena apontou diversos entraves para a efetivação da política de saúde indígena: o despreparo dos profissionais de saúde para atuar com indígenas; a dificuldade dos profissionais não - indígenas de entender e aceitar as concepções e práticas terapêuticas nativas; as práticas de saúde utilizadas na atenção à saúde indígena fundamentadas na biomedicina, com a tentativa de medicalização de problemas sociais; e o desconhecimento em relação à medicina tradicional indígena (RIBEIRO et al, 2015).

Garnelo (2012), com base nas informações publicizadas por diversos autores sobre avaliações parciais do subsistema de saúde indígena, cita a recorrência de entraves como o atendimento descontínuo e de baixa qualidade técnica à população aldeada, elevada rotatividade e/ou ausência de profissionais de saúde para realizar as ações assistenciais, escassez de materiais e equipamentos necessários à realização de ações de saúde, dificuldades para transportar os profissionais de saúde até as aldeias, dentre outros.

Nesse sentido cabe a reflexão: será que profissionais indígenas atuando na assistência à saúde indígena minimizariam ou apoiariam a resolução de alguns desses entraves?

O exemplo dos AIS nos aponta elementos críticos valiosos a essa discussão. Pontes, Stauffer e Garnelo (2012) relembram que cada aldeia deve possuir um posto de saúde com AIS, os quais devem facilitar a conexão entre a comunidade, seus 
saberes tradicionais e a equipe de saúde, tendo como atribuições: acompanhar o crescimento e desenvenvolvimento infantil, acompanhar as gestantes, atender aos casos de doença mais frequentes, acompanhar pacientes crônicos, acompanhar a vacinação, dentre outras.

Porém, para realizar as atividade inerentes à profissão os AIS são submetidos a processo formativo, que segundo Pontes, Stauffer e Garnelo (2012), são centrados no saber biomédico, não incluem discussões sobre a interculturalidade no processo saúde-doença ou sobre as medicinas tradicionais indígenas. Menéndez (2003), contribui ao afirmar que no âmbito do enfoque biomédico da saúde o campo mais excluído é o cultural, o que explica em partes a estruturação da formação para AIS no Brasil.

E nessa perspectiva de exclusão das singularidades culturais dos (as) trabalhadores (as) indígenas, surge a desvalorização dos AIS pelos outros profissionais de saúde e a sua subordinação hierárquica a todos os outros membros da equipe de saúde, o que é agravado pelo não conhecimento pleno dos saberes biomédicos, como apontado por Pontes, Stauffer e Garnelo (2012), Rocha (2007), Scopel, Dias-Scopel e Langdon (2015), dentre outros. Diehl, Langdon e Dias-Scopel (2012), caracterizam a relação entre os AIS e os outros membros da equipe de saúde indígena como formal e assimétrica.

Os AIS frequentemente se percebem alvos de preconceitos e que seu trabalho não recebe 0 reconhecimento dos membros das Equipes Multidisciplinares de Saúde Indígena (EMSI), nem dos profissionais nos serviços da rede de referência do SUS, aos quais eles muitas vezes servem de acompanhantes. Certamente, um fator que contribui para essa situação, além da natureza hierárquica implícita nos serviços médicos, é a falta de reconhecimento de seu papel como profissional (DIEHL, LANGDON, DIASSCOPEL, 2012. .p. 824).

Esses pontos não podem ser entendidos apenas como entraves para a eficácia do subsistema de saúde indígena, mas também, e principalmente, para o desenvolvimento pessoal e profissional do (a) trabalhador (a) indígena de saúde. Rocha (2007), aponta que Agentes Indígenas ligados ao Distrito Sanitário Especial Indígena Alto Rio Negro, localizado no Amazonas, enfrentaram diversos problemas no âmbito do trabalho em saúde, como por exemplo: se tornarem vítimas de depreciação por parte das equipes de saúde (não-indígenas), por conta de baixa qualificação (nos saberes biomédicos) para atuar junto ao sistema oficial de saúde; intolerância da equipe de saúde com as atividades da vida cotidiana dos AIS, como 
a caça, a pesca para alimentar suas famílias, a interação social em festas e visitas aos parentes, dentre outros.

Esses aspectos trazidos por Rocha (2007) soam muito além de simples problemas de processo de trabalho ou da vivência intercultural no trabalho em saúde indígena, mas se configuram como práticas racistas e discriminatórias contra os Agentes Indígenas de Saúde atuantes no subsistema de saúde indígena. Torna-se evidente a delicadeza que envolve inserir na atenção à saúde indígena profissionais não-indígenas que não estão dispostos a respeitar e valorizar a singularidade cultural dos povos indígenas, reforçando que não se trata do respeito apenas aos usuários, mas também aos profissionais indígenas que atuam nas equipes de saúde.

Trazendo à tona mais uma vez a ampliação do acesso de indígenas ao ensino superior, incluindo as graduações da área da saúde, como abordado no capítulo 2.3, obviamente ocorrerá crescente formação de força de trabalho indígena para atuar no subsistema de saúde indígena e no SUS, emergindo daí mais um elemento importante para a reflexão: Como o SUS e o subsistema de saúde indígena, irão se preparar para captar essa força de trabalho indígena, e principalmente, como a intolerância, o racismo e a discriminação racial disparada contra os indígenas será enfrentada, afim de apoiar a adaptação, permanência e desenvolvimento do (a) profissional indígena ao sistema de saúde não-indígena?

Trazendo outra perpectiva, Scopel, Dias-Scopel, Langdon (2015), apresentam resultados animadores de uma pesquisa etnográfica realizada com os AIS do povo Munduruku do Amazonas. Entre os achados, as autoras evidenciam: a atuação dos agentes indígenas como atores políticos emergentes no contexto interétnico, passando a ocupar, na equipe de saúde e na comunidade, centralidade no campo das negociações entre as distintas formas de cuidar; manutenção da medicina tradicional no desenvolvimento do processo de trabalho (orientação de tratamento com o pajé e uso de remédios do mato); e extrapolação do papel do (a) AIS apenas para o sistema de saúde, passando a ser requisitado (a) pelas lideranças locais para discussões de aspectos referentes à saúde e ao acompanhamento dos trabalhos desenvolvidos pela equipe de saúde do DSEI.

A experiência dos AIS Munduruku apontada por Scopel, Dias-Scopel, Langdon (2015), apesar de apontar elementos positivos envolvendo a interculturalidade e intermedicalidade entre profissionais indígenas e não-indígenas, também aponta um elemento sutil capaz de passar despercebido para alguns. Os 
autores relatam que alguns dos AIS exerciam outras atividades além daquelas descritas como suas atribuições, o que incluia serviços de limpeza e organização de estoques e insumos e arquivos de documentos. Diante da realidade vivenciada por indígenas de outros povos que enfrentam a subordinação preconceituosa perante à equipe de saúde, vale destacar esse fato, afim de evitar processos naturalizados de discriminação e racismo contra os (as) AIS e outros profissionais indígenas que atuem na área atualmente e num futuro próximo.

Nota-se pelos registros realizados por Pontes, Stauffer e Garnelo (2012) e Rocha (2007) que em algumas realidades ainda não existe espaço para a diversidade cultural e para o respeito e a valorização dos conhecimentos tradicionais dos (as) profissionais indígenas de saúde. Ao passo que, em outras localidades, a comunicação intercultural realizada entre os (as) AIS e os (as) profissionais não indígenas tem ocorrido como potencializador da atenção à saúde, empoderando também o (a) profissional indígena diante de sua comunidade (SCOPEL, DIASSCOPEL, LANGDON, 2015). Será assertivo conjecturar que esses cenários desfavoráveis se apresentarão também aos profissionais indígenas de nível superior que nos próximos anos comporão a atenção no subsistema de saúde indígena? Ou cabe manter a esperança de que experiências exitosas e respeitosas se multiplicarão em outras comunidades?

Toda essa discussão sobre a força de trabalho indígena na saúde apontada no presente capítulo ganha centralidade como reinvindicação das organizações que compõem o movimento indígena e dos povos indígenas como um todo, comprovando o protagonismo indígena em torno do tema. As propostas aprovadas durante a 5aㅡ Conferência Nacional de Saúde Indígena são exemplo claro disso, já que demonstram a demanda por ampliação da captação e valorização dos (as) profissionais indígenas no mercado de trabalho em saúde, especificamente pelo subsistema de saúde indígena (BRASIL, 2015).

Diversas propostas evidenciaram a demanda por criação de concurso público específico para a saúde indígena, que seja diferenciado para indígena, provendo cotas de $80 \%$ das vagas para profissionais indígenas e $20 \%$ para não indígenas, bem como pontuações específicas para profissionais indígenas, como forma de valorizar os indígenas formados na área da saúde e responder às especificidades culturais das diversas etnias. Foi evidenciado também a necessidade de criação de lei específica que determine os parâmetros de contratação, via CLT, de profissionais 
para a saúde indígena, o que inclui processo seletivo diferenciado e regionalizado, priorizando os profissionais indígenas, tendo a participação ativa dos caciques, lideranças e da comunidade indígena em questão (BRASIL, 2015).

Os povos indígenas também demandaram a criação de uma política específica de recursos humanos voltada para à saúde indígena, o que auxiliaria na concretização das propostas aprovadas na $5^{\text {a }}$ Conferência Nacional, na captação e valorização dos profissionais indígenas e não-indígenas e na qualificação da força de trabalho em saúde que atua nos territórios indígenas, por meio de cursos específicos e residências em saúde indígena, o que consequentemente impactaria positivamente no próprio serviço de saúde indígena (BRASIL, 2015).

Assim, dada a importância da temática para os povos indígenas e para as políticas públicas, vale destacar a relevância da realização de estudos que visem acompanhar as experiências de profissionais indígenas de saúde (em todos os níveis de formação), inseridos na assistência à saúde indígena e não-indígena, buscando conhecer a realidade que os cercam, elaborar e/ou aprimorar os mecanismos de combate ao racismo, a exclusão e a discriminação contra os (as) profissionais indígenas no mercado de trabalho em saúde e estimular a troca de experiências de respeito à diversidade, de trocas interculturais entre sistemas diferenciados de saúde (oficial e indígena) e de empoderamento do (a) profissional indígena de saúde. 


\section{OBJETIVOS}

3.1 OBJETIVO GERAL: Analisar a presença de profissionais indígenas na assistência à saúde no Brasil.

\subsection{OBJETIVOS ESPECÍFICOS:}

3.2.1 Identificar o quantitativo de profissionais indígenas de nível superior atuantes na assistência à saúde no Brasil;

3.2.2 Identificar o quantitativo de indígenas matriculados em instituições de ensino superior (IES) no Brasil;

3.2.3 Detectar os pincipais nós críticos relacionados à Força de Trabalho Indígena de nível superior da Assistência à Saúde no Brasil. 


\section{PERCURSO METODOLÓGICO}

Trata-se de uma pesquisa descritiva exploratória, já que se propõe a realizar levantamento inédito sobre os profissionais indígenas que atuam na assistência à saúde no Brasil. Segundo Gil (2008) a pesquisa descritiva tem como objetivo primordial a descrição das características de determinada população ou fenômeno ou o estabelecimento de relações entre variáveis, tendo como aspecto importante a utilização de técnicas padronizadas de coleta de dados. Ao tempo que se aproxima da pesquisa exploratória, por objetivar gerar visão geral, de tipo aproximativo, acerca de determinado fato ainda pouco explorado, no caso a realidade do trabalhador indígena na assistência à saúde, sendo difícil por conta disto, formular hipóteses com precisão e possibilidade de operacionalização. Comumente as pesquisas exploratórias constituem a primeira etapa de investigações mais amplas (GIL, 2008).

É ainda de natureza aplicada, já que objetiva a geração de conhecimento de aplicação prática, voltada para o enfrentamento das desigualdades raciais no mercado de trabalho em saúde, geradas como fruto do processo sóciohistórico de colonização, opressão, dominação, o que consequentemente trouxe a exclusão dos indígenas brasileiros no que tange a oportunidades sociais ligadas aos direitos básicos assegurados legalmente pela "cidadania", como o acesso à formação e ao mercado de trabalho. A abordagem da pesquisa é quantitativa, realizada por meio de consulta à base de dados secundários.

A pesquisa foi realizada no período de janeiro de 2016 a janeiro de 2017, como requisito para conclusão do mestrado profissional em Saúde Coletiva na Universidade de Brasília, ligado à Faculdade de Ciências da Saúde e ao Programa de Pós Graduação em Saúde Coletiva.

O processo de revisão da literatura foi orientada pelas seguintes perguntas norteadoras: 1 - Quem são e como vivem os indígenas do Brasil? 2- Os indígenas são de fato cidadãos, segundo os referenciais teóricos que tratam da temática e as condições de vida que levam na realidade brasileira? 3 - Qual o panorama da força de trabalho indígena de nível superior na saúde? 4 - Existem produções na literatura que abordam a gestão do trabalho indígena? 5 - Existe formação de força de trabalho indígena no ensino superior no Brasil? Estas questões norteadoras 
orientaram a estruturação do referencial teórico que se dividiu em 4 (quatro) partes: 1a - Povos indígenas do Brasil; 2 ${ }^{a}$ Índio cidadão?; 3a Formação de indígenas no ensino superior no Brasil; e 4⿳亠丷a - Força de Trabalho em Saúde: onde se encaixam os indígenas.

Para definição das bases de dados a serem incluídas neste estudo considerou-se àquelas presentes na Plataforma Força de Trabalho em Saúde (PFTS), ambiente virtual de livre acesso público, que reúne e disponibiliza dados sobre a força de trabalho empregada na assistência à saúde no Brasil, estabelecimentos de saúde, equipamentos utilizados, postos de trabalho e residências médicas. A PFTS foi lançada ao público no ano de 2015 pela Secretaria de Gestão do Trabalho e da Educação na Saúde (SGTES) do MS, juntamente com o Departamento de Gestão e da Regulação do Trabalho em Saúde (DEGERTS), o qual é responsável pela coordenação da Plataforma (BRASIL, 2015).

Segundo o MS, a PFTS visa subsidiar a geração de informações e conhecimento sobre recursos humanos em saúde para gestores e pesquisadores da área da saúde. Para tanto, disponibiliza dados de diferentes bancos, como do Cadastro Nacional de Estabelecimentos de Saúde (CNES/MS), da Relação Anual de Informações Sociais (RAIS)/Ministério do Trabalho e Emprego (MTE), do Sistema da Comissão Nacional de Médicos Residentes (CNRM)/Ministério da Educação (MEC), do Instituto Brasileiro de Geografia e Estatística (IBGE) e da Receita federal (BRASIL, 2016). Para cumprir os objetivos traçados nesse estudo considerou-se os bancos de dados da RAIS/MTE e do CNES/MS, já que ambos trazem os dados sobre a força de trabalho desagregados por raça/cor.

A Relação Anual de Informações Sociais nada mais é do que um registro administrativo nacional ligado ao Ministério do Trabalho e Emprego, obrigatório a todos os estabelecimentos/empresas, inclusive para aqueles que não possuem vínculos empregatícios no período. Criado desde 1975, possui periodicidade anual e serve atualmente como única fonte para o pagamento do abono salarial. Fornece importantes informações para a caracterização e acompanhamento do mercado de trabalho formal no Brasil (IBGE, 2016). Vale ressaltar, que apesar da potencialidade da RAIS para caracterizar a força de trabalho na área da saúde, o referido banco de dados foi excluído da pesquisa, devido a não consideração da opção "indígena" na estratificação dos dados de força de trabalho por raça/cor. As categorias consideradas na RAIS são: branca, negra, amarela e outras. Sendo assim, essa 
estratificação inviabilizava a utilização dos dados para o levantamento da força de trabalho indígena empregada na saúde.

O CNES por sua vez, é um banco de dados de origem pública, considerado documento público e sistema de informação oficial de cadastramento de informações de todos os estabelecimentos de saúde do Brasil, independente de sua natureza jurídica ou de integrarem ou não o SUS, de acordo com a Portaria 1.646, de 2 de outubro de 2015, do Ministério da Saúde.

O CNES legalmente deve responder as seguintes finalidades:

I - cadastrar e atualizar as informações sobre estabelecimentos de saúde e
suas dimensões, como recursos físicos, trabalhadores e serviços; II -
disponibilizar informações dos estabelecimentos de saúde para outros
sistemas de informação; III - ofertar para a sociedade informações sobre a
disponibilidade de serviços nos territórios, formas de acesso e
funcionamento; e IV - fornecer informações que apoiem a tomada de
decisão, o planejamento, a programação e o conhecimento pelos gestores,
pesquisadores, trabalhadores e sociedade em geral acerca da organização,
existência e disponibilidade de serviços, força de trabalho e capacidade
instalada dos estabelecimentos de saúde e territórios (BRASIL, 2015, p. 2).

A finalidade IV acima descrita, explica a escolha do CNES como banco de dados central no presente estudo, já que se propõe a fornecer informações sobre a força de trabalho nos diversos estabelecimentos de saúde no Brasil (BRASIL, 2015), tendo atualização mensal na Plataforma Força de Trabalho em Saúde/MS, o que responde de imediato ao objetivo de identificar o quantitativo de profissionais indígenas de nível superior atuantes na assistência à saúde no Brasil, que nesse caso foi realizado utilizando os dados do mês de outubro de 2016 do CNES fornecidos pela PFTS.

$\mathrm{Na}$ sequência, buscando a complementação dos dados fornecidos pelo sistema de informação CNES/PFTS, recorreu-se ao Ministério da Saúde, especificamente à Secretaria Especial de Saúde Indígena (SESAI/MS), por meio do Sistema Eletrônico do Serviço de Informação ao Cidadão (E-sic), ancorada na Lei de acesso à informação, buscando dados referentes à força de trabalho atuante nos serviços de saúde indígena. Os dados foram solicitados priorizando o recorte racial, visando realizar a mensuração dos trabalhadores indígenas e não-indígenas da área. A SESAI realizou articulação com as 3 (três) instituições contratantes da força de trabalho na saúde indígena no Brasil em 2016, o Instituto de Medicina Integral Professor Fernando Figueira (IMIP), a Associação Paulista para o Desenvolvimento da Medicina (SPDM) e a Missão Evangélica Caiuá para levantamento dos dados 
solicitados.

Sendo assim, ao final decidiu-se que a população alvo do estudo são os profissionais indígenas de saúde de nível superior que atuavam na assistência à saúde no Brasil no ano de 2016, informados pela Plataforma Força de Trabalho em Sáude como profissionais de saúde no Cadastro Nacional de Estabelecimentos de Saúde. Bem como àqueles informados pelas três instituições filantrópicas que realizam a contratação de pessoal para atuar na saúde indígena, vinculadas à SESAI/MS, como citado anteriormente. Vale ressaltar que a PFTS, atualmente, para levantar a composição racial da força de trabalho apontada pelo CNES cruza dois bancos de dados, o do CNES e do Cartão Nacional de Saúde (CNS).

Considerou-se, para fins de delimitação da população de estudo, as 14 (quatorze) profissões de saúde disponibilizadas pela PFTS (BRASIL, 2016). Essas profissões de Saúde foram selecionadas de acordo com a resolução ํㅡㄹ 287/98 do Conselho Nacional de Saúde (CNS), que relaciona 14 categorias profissionais de nível superior para fins atuação e representação no âmbito desse Conselho, são elas: Serviço social, Biologia, Biomedicina, Educação Física, Enfermagem, Farmácia, Fisioterapia, Fonoaudiologia, Medicina, Medicina Veterinária, Nutrição, Odontologia, Psicologia e Terapia Ocupacional (BRASIL, 1998). Porém, é importante ressaltar que a assistência à saúde no Brasil é composta por uma gama de profissões de saúde, de diferentes níveis de escolaridade, que contribuem para o alcance do atendimento integral à população brasileira, mas para fins de delimitação do objeto e por esta resolução do CNS ser uma referência utilizada na prática da gestão do trabalho no SUS, escolheu-se analisar as 14 (quatorze) profissões supracitadas.

Os instrumentos que orientaram a coleta de dados foram construídos pela pesquisadora no intuito de facilitar a sistematização e posterior análise dos dados, os quais são: 1 - o fluxograma orientador de busca em sítio eletrônico - Plataforma da Força de Trabalho em Saúde (Apêndice A), composto por todos os passos necessários para coletar os dados sobre os trabalhadores (as) indígenas na assistência à saúde; 2 - a descrição do fluxograma orientador de busca em sítio eletrônico - Plataforma Força de Trabalho em Saúde (Apêndice B), contendo a descrição dos passos apontados no apêndice B; 3 - a Matriz de sistematização da força de trabalho em saúde no Brasil (Apêndice $C$ ) com os campos: profissão, fonte de dados, total, profissionais por raça/cor no Brasil e percentual de profissionais por 
raça/cor no Brasil; 4 - Matriz de sistematização da Força de Trabalho Indígena em Saúde por região e estado (Apêndice D) contendo os seguintes campos: profissão, região, fonte de dados, total por região, total por estado, profissionais indígenas por região, percentual de profissionais indígenas por região, profissionais indígenas por estado e percentual de profissionais indígenas por estado; 5 - Matriz de sistematização dos dados de Saúde Indígena - SESAI/IMIP/SPDM/Caiuá - atenção á saúde (Apêndice E), contendo dados referentes à categoria profissional, local de atuação, total da categoria, instituição contratante, quantitativo de profissionais de nível superior, considerando as 14 profissões de saúde, indígenas e não indígenas, quantitativo de "sem informação de raça/cor"; 6 - o fluxograma orientador de busca em sítio eletrônico - Instituto de Pesquisa Anísio Teixeira (INEP) - apresentando os passos necessários para encontrar e baixar os dados referentes às sinopses da educação superior realizada pelo INEP, no período de 2011 a 2015. (Apêndice F); e a descrição do fluxograma orientador de busca em sítio eletrônico - Instituto de Pesquisa Anísio Teixeira (INEP) (Apêndice G), contendo a descrição dos passos apontados no apêndice $F$.

A sistematização dos dados foi realizada utilizando o programa Excel do Microsoft Oficce, 2013, a partir das matrizes de coleta gerando informações para análise. As variáveis de análise utilizadas no levantamento dos dados do CNES, por meio da Plataforma Força de Trabalho em saúde foram: profissionais das 14 profissões de saúde, com formação de graduação e/ou pós graduação, atuantes na assistência à saúde no Brasil e cadastrados no CNES, desagregados por raça/cor, profissão, região geográfica e unidade da federação. Em se tratando das variáveis de análises ligadas SESAI/MS/IMIP/SPDM/Caiuá, foram priorizadas os profissionais de nível superior das 14 (quatorze) profissões de saúde objeto da pesquisa, atuantes na assistência à saúde indígena. $O$ foco de análise foi direcionado para a identificação dos profissionais indígenas e não-indígenas por categoria profissional e instituição contratante, no ano de 2016.

Os dados coletados e sistematizados foram analisados tendo como base o contexto histórico e social da população indígena no Brasil, conforme descrito nos capítulos 2.1 e 2.2, permitindo o diálogo da abordagem quantitativa com informações qualitativas que apoiam o melhor entendimento da realidade. Nesta perspectiva de contextualização dos dados quantitativos é que foi levantada a série histórica das matriculas de indígenas na educação superior no Brasil, propondo o paralelo entre a 
formação profissional e o mercado de trabalho. Esta contextualização buscada na pesquisa se fundamenta nos apontamentos de Cecília Minayo sobre a insuficiência, limites e especificidades das abordagens de pesquisa, destacando que:

"De que adianta ao investigador utilizar instrumentos altamente sofisticados de mensuração quando estes não se adequam à compreensão de seus dados ou não respondem a perguntas fundamentais? Ou seja, uma pesquisa, por ser quantitativa, não se torna "objetiva" e "melhor", caso desconheça aspectos importantes dos fenômenos ou processos sociais estudados" (MINAYO, 1993, p. 247)

Foram realizados cálculos de proporção ou distribuição proporcional, através da fórmula: proporção= № parcial de casos / № total de casos $\times 100$; Frequência absoluta, a partir dos quantitativos de força de trabalho extraídos do CNES/PFTS, SESAI, IMIP, SPDM e Missão Evangélica Caiuá; e, Taxa de Crescimento Percentual Anual das matriculas de indígenas em IES, considerando a série histórica de 2010 a 2015, calculada através da formula: valor final de matriculas de indígenas em IES valor inicial de matriculas de indígenas em IES / valor inicial x 100.

As variáveis e indicadores utilizados para análise dos dados e produção de informações podem ser conferidas no quadro 1 , como segue abaixo.

Quadro 1 - Variáveis e indicadores utilizadas para análise dos dados referentes à Força de Trabalho Indígena na Assistência à Saúde no Brasil.

\section{VARIÁVEIS}

Frequência absoluta e relativa da força de trabalho por profissão de saúde; Frequência relativa dos profissionais atuantes na assistência à saúde no Brasil que não declararam raça/cor no CNES, por categoria profissional;

Frequência absoluta de indígenas matriculados em IES, de 2010 a 2015;

Frequência absoluta de profissionais indígenas na assistência à saúde, desagregada por categoria profissional;

Frequência absoluta de indígenas por categoria profissional e distribuída por região geográfica;

Frequência absoluta de profissionais indígenas atuantes na assistência por Unidade da Federação;

Frequência absoluta de profissionais componentes das 14 profissões de saúde atuantes na assistência à Saúde Indígena;

\section{INDICADORES}

Proporção de profissionais na assistência à saúde no Brasil por raça/cor, em percentual;

Diferença na proporção de indígenas na força de trabalho da assistência em relação a Brancos, Negros e Amarelos;

Taxa de crescimento anual de indígenas matriculados em IES, em percentual; 


\section{Proporção de profissionais indígenas atuantes na Saúde Indígena, desagregada por categoria profissional.}

Os resultados da pesquisa foram organizados em seis blocos, buscando torna-los mais claros e compreensíveis, são eles: 1- Força de Trabalho de nível superior na assistência à saúde, segundo o CNES; 2- Profissionais de saúde por raça/cor e a presença de indígenas na assistência à saúde no Brasil; 3- Indígenas no Ensino Superior no Brasil; 4 - Profissionais indígenas por categoria profissional e localização geográfica; 5 - Força de Trabalho indígena empregada na Saúde Indígena; e 6 - Principais nós críticos relacionados à Força de Trabalho Indígena em Saúde.

Os procedimentos éticos da pesquisa foram respeitados em todas as etapas do processo. Considerando que esta pesquisa utilizou dados secundários públicos, solicitou dispensa do Termo de Consentimento Livre e Esclarecido (TCLE) ao Comitê de Ética em Pesquisa da Faculdade de Ciências da Saúde da UnB, a qual foi encaminhada e aprovada pela Comissão Nacional de Ética em Pesquisa (CONEP), por se tratar de pesquisa com povos indígenas.

Com relação aos riscos de pesquisa, e considerando que todas as pesquisas oferecem algum grau de risco, a pesquisa em questão poderá evidenciar categorias profissionais mais ou menos excludentes e/ou grupos étnicos expostos a maior grau de desigualdade no mercado de trabalho, podendo gerar impacto nos envolvidos. Portanto, para minimizar essas questões, pensou-se em abordar o contexto que envolve as categorias profissionais e a situação de desigualdade em sua vertente sócio histórica, o que retira a responsabilidade do campo individual e as reorienta para o campo coletivo nesse processo de construção. Sobre a evidenciação dos processos de exclusão dos povos indígenas, ao fim da pesquisa, a pesquisadora irá veicular os resultados às organizações que compõem o movimento indígena brasileiro e às organizações e instituições governamentais envolvidas com a questão, evidenciando alguns dos nós críticos que envolvem as iniquidades raciais com indígenas no mercado de trabalho em saúde, o que poderá auxiliar na recomendação de medidas que visem reverter e/ou minimizar tal contexto. 


\section{RESULTADOS E DISCUSSÃO}

\subsection{FORÇA DE TRABALHO DE NÍVEL SUPERIOR NA ASSISTÊNCIA À SAÚDE}

A análise dos dados oriundos do Cadastro Nacional de Estabelecimentos de Saúde evidenciou extrema iniquidade racial existente no mercado de trabalho da assistência à saúde no Brasil, e comprovou a presença de indígenas de nível superior atuando como profissionais de saúde da assistência no âmbito do SUS e/ou em serviços privados, o que pode englobar tanto o cuidado à população geral (não indígena) quanto nos territórios indígenas, como profissionais da área específica de Saúde Indígena.

Nota-se que a Força de Trabalho das 14 (quatorze) profissões de saúde de nível superior, do setor público e privado, cadastrada no CNES, é formada em maior número por profissionais da Medicina (339.315 mil), da Enfermagem (192.896 mil) e da Odontologia (117.470), representando respectivamente $37,7 \%, 21,4 \%$ e $13 \%$ da força de trabalho da assistência à saúde.

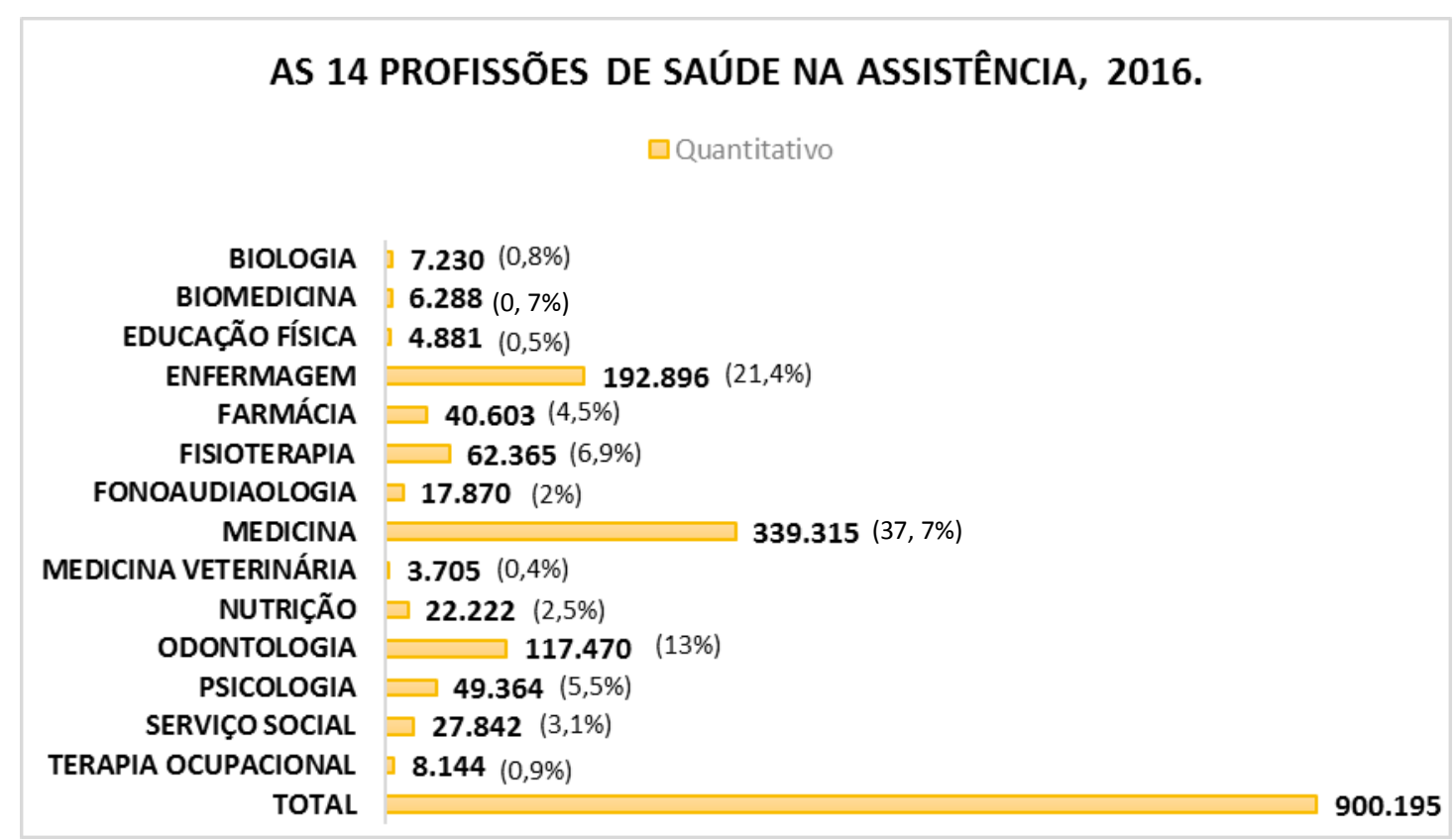

Figura 1 - Força de Trabalho de nível superior empregada na Assistência à Saúde no Brasil, considerando as 14 profissões de saúde, 2016.

Fonte: PFTS, 2016; CNES, 2016. 
As três profissões de saúde que possuem maior expressividade quantitativa na assistência pelo CNES são também aquelas que constituem as equipes mínimas de Saúde da Família no âmbito do SUS, juntamente com os Agentes Comunitários de Saúde (ACS), auxiliares e técnicos de enfermagem e de consultório dentário, como posto na Política Nacional de Atenção Básica (PNAB) (BRASIL, 2012).

Assim sendo, torna-se visível que as políticas de saúde postas pelo Estado e pelos governos interferem na conformação da Força de Trabalho em Saúde nos estados e municípios, uma vez que sugerem aos municípios e estados determinada categoria profissional para o desenvolvimento de ações e execução das políticas de saúde, como é o caso da Estratégia de Saúde da Família com a equipe mínima e do Núcleo de Apoio à Saúde da Família (NASF) com as equipes multiprofissionais (Nutrição, Psicologia, Serviço Social, Educação Física, Fisioterapia, dentre outras de escolha dos territórios) que se mostraram bastante expressivas, como expresso na figura 1.

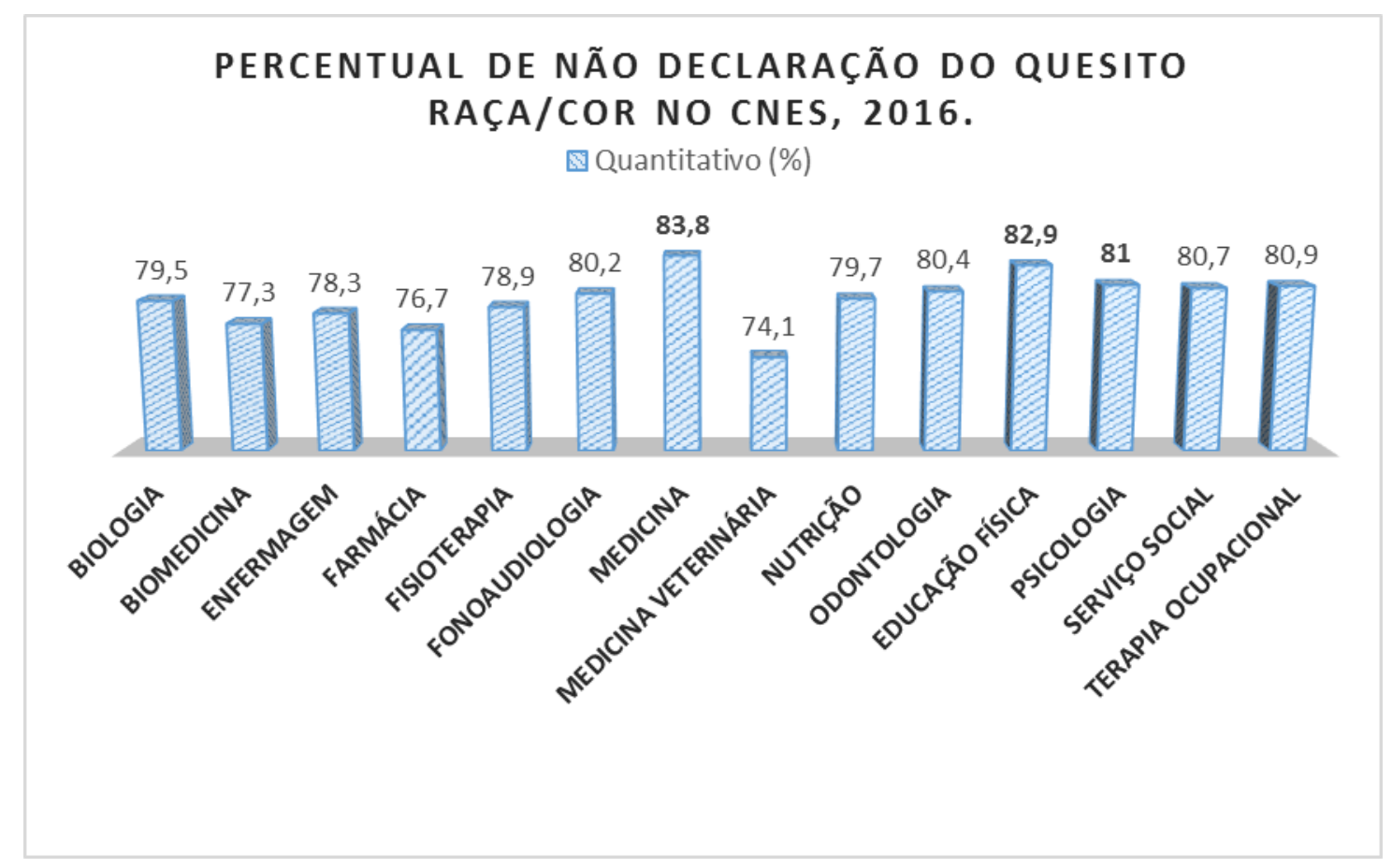

Figura 2 - Percentual de profissionais atuantes na assistência à saúde no Brasil que não declararam raça/cor no CNES, por categoria profissional, no ano de 2016.

Fonte: PFTS, 2016; CNES, 2016.

A figura 2 realça uma lacuna importante e já conhecida relacionada ao preenchimento do quesito raça/cor no CNES, que é a quantidade significativa de não preenchimento desse campo. Em todas as profissões de saúde 0 não 
preenchimento do quesito raça/cor se mostrou bastante elevado, tendo os maiores percentuais situados nas seguintes profissões: Medicina, em 1 o lugar, Educação Física, em $2^{\circ}$ e Psicologia, em $3^{\circ}$. Porém, apesar da presença dessa importante lacuna, a escolha de manter a raça como questão central do estudo através do CNES se deu pela necessidade de extrapolar o campo de constatação da lacuna, evidenciando a relevância em compreender os fatores que envolvem a autodeclaração da raça no Brasil (SANTOS, COELHO, ARAÚJO, 2013), e por ser o CNES, o sistema oficial disponível na saúde para o levantamento da Força de Trabalho em saúde (BRASIL, 2015).

É importante pensar nos motivos que orientam o não preenchimento do quesito "raça/cor" nesse sistema de informação. Nesse caso, as reflexões podem seguir dois caminhos diferentes. Um que liga-se à dinâmica de estruturação legal do CNES estabelecida pelo MS e outra que associa-se à complexidade sociocultural de tal declaração. Para ambas cabem as seguintes reflexões: A que pode-se atribuir tal lacuna? Quem não preencheu a ficha de cadastro do profissional? Quem deveria preenchê-la? (O próprio profissional de saúde ou a gestão local)? A raça/cor se daria por hétero ou autodeclaração? Essas questões não esclarecidas relacionadas ao CNES, e consequentemente ao não preenchimento do quesito raça/cor, encontram brecha para existir na legislação vigente que trata do CNES (BRASIL, 2015) e nas produções técnicas que orientam tais procedimentos (BRASIL, 2006).

Se por um lado a legislação obriga todos os estabelecimentos de saúde que funcionam no Brasil a se cadastrarem no CNES, juntamente com seus profissionais de saúde, destacando a necessidade dos profissionais de saúde serem corresponsáveis por suas informações pessoais e profissionais (BRASIL, 2015), por outro, nem a legislação nem os documentos técnicos que orientam o preenchimento das fichas do CNES esclarecem quem, de fato, deve preencher o cadastro dos profissionais, o que inclui as informações de raça/cor, gerando dubiedade nas interpretações e nas práticas profissionais relacionadas a alimentação do CNES nos estabelecimentos e secretarias de saúde.

Associado aos pontos supracitados, tem-se orientações divergentes acerca do preenchimento da ficha de cadastro, variando de acordo com o local de atuação dos profissionais, se em estabelecimentos do SUS ou da rede privada. De forma mais clara, as orientações técnicas do Ministério da Saúde referentes a tal preenchimento evidenciam que profissionais de saúde que não atuam na rede do 
SUS, o que inclui os estabelecimentos privados conveniados ou contratados pelo SUS, não são obrigados a preencher a ficha completa, o que já exclui o campo raça/cor para os profissionais de saúde da rede privada, já que o mesmo se torna facultativo. Já para os profissionais atuantes em estabelecimentos ligados ao SUS é obrigatório o preenchimento de todos os campos que constituem a ficha de cadastro (BRASIL, 2006). Percebe-se que essas orientações diferentes podem também contribuir para essa significativa lacuna na identificação racial da força de trabalho em saúde.

No que tange a compreensão da declaração racial no CNES (hétero ou autodeclaração), vale aponta-la não apenas como um simples quesito, como por exemplo o número de CPF ou endereço, e sim, destaca-la em sua complexidade, o que exige reflexões mais aprofundadas e contextualizadas com a realidade brasileira. Santos, Coelho e Araújo (2013) em seu trabalho intitulado "identificação racial e a produção da informação em saúde", evidenciam a raça enquanto categoria constituída historicamente por pessoas que são vítimas de desvantagens sociais geradas pelo preconceito e discriminações relacionadas à sua origem étnica e/ou às características que são portadoras, como por exemplo, a cor e outras características fenotípicas. Destacam a influência dos determinantes socioeconômicos e políticoculturais na saúde da população, dentre eles o quesito racial, que no Brasil possui centralidade incontestável na formação dos povos brasileiros.

As autoras revelam um pouco da complexidade da identidade racial, ao colocarem-na como um aspecto que constitui a identidade do indivíduo, se construindo de maneira subjetiva, a partir da consciência que o sujeito tem de si mesmo e de forma objetiva, a partir do seu reconhecimento no meio em que vive pelo outro. Porém, considerando o Brasil e a história de sua formação, engendrada por violências e dominações perversas, torna-se claro que a questão racial nesse território teve na estratégia de embranquecimento conhecida como miscigenação o solo fértil para o enraizamento do mito da democracia racial, que enfraqueceu os povos e as memórias históricas, contribuindo para o não reconhecimento racial dos indivíduos (SANTOS, COELHO, ARAÚJO, 2013).

Sales Júnior (2006), reconhece que a miscigenação pluralizou, matizou e modalizou a discriminação, levando em consideração principalmente a cor da pele do indivíduo. Corroborando com o autor, Santos, Coelho e Araújo (2013) destacam que é a diferença que traz à tona a injustiça e que o ditado comumente utilizado de 
que somos todos brasileiros se apresenta enquanto realidade que "dilui e invisibiliza o efetivo limiar que é não ser branco" (SANTOS, COELHO, ARAÚJJ, 2013. p. 11). Questionam ainda se não seria a imagem de um país miscigenado utilizada para promover a fuga do debate sobre as desigualdades raciais no Brasil?

$E$ ainda, parece pertinente pensar que a miscigenação associada ao mito da democracia racial transformou-se em barreira ao pertencimento e auto reconhecimento étnico-racial no Brasil, podendo ser um dos fatores sócio-históricoculturais ligado a lacuna gigantesca existente no não preenchimento do quesito raça/cor no CNES. Para Santos, Coelho e Araújo (2013) as ações de omissão da definição racial geram distorções e estatísticas de raça/cor não confiáveis, porém, são antes de tudo produzidas por processo social que orienta a prática dos profissionais. Logo, a leitura racial da força de trabalho em saúde e da lacuna que se apresenta associada, exige a curiosidade de entender o fenômeno social que a envolve.

$\mathrm{Na}$ literatura essa lacuna referente ao não preenchimento do quesito raça/cor e/ou à sua complexidade é citada como "uma névoa informacional conveniente [...] revelando a ineficácia do Estado" (SANTOS, COELHO, ARAÚJO, 2013. p. 13). Essa ineficácia do Estado está justamente situada na ausência de medidas específicas de enfrentamento da situação, tendo na omissão um caminho menos polêmico e mais confortável a seguir. De acordo com as mesmas autoras, uma forma de enfrentamento necessária é o investimento para que os sujeitos que estão envolvidos com as informações em saúde se tornem mais conscientes da relevância social desses dados, tendo desta forma sujeitos mais sensíveis à vulnerabilidade que a identidade sociorracial confere aos indivíduos, buscando assim, a construção de uma nova compreensão sobre a raça/cor da pele no Brasil.

Diante disso é possível apontar a lacuna no preenchimento do quesito raça/cor no CNES também como possível fruto de um processo sócio histórico longo de enfraquecimento da diversidade dos povos e da consciência étnico-racial individual e coletiva, o que leva ao silêncio de muitos sistemas de informação em saúde, que na verdade soa mais como gritos que contam o passado próximo dos brasileiros e evidenciam a invisibilidade de indígenas e negros. Segundo Santos, Coelho e Araújo (2013. p. 12), "a invisibilidade é uma das mais hediondas formas de violência que, por sua vez, leva à sua naturalização. Não é visto, não existe, logo, não é importante". 
Então, quem são esses milhares de profissionais de saúde sem traços, sem origem e sem história que estão no CNES? Qual a relevância de tal informação para as políticas públicas, para os movimentos sociais e sociedade civil? E qual o retorno individual e coletivo que estes sujeitos teriam em contribuir com a sua memória e história, além de dores e pesares históricos?

Para este estudo, considerar a lacuna do quesito raça/cor no CNES enquanto resultado de pesquisa já representa uma contribuição no sentido de evidenciar que a ausência da informação pode estar calcada tanto na dinâmica de estruturação do sistema quanto em processos sócio históricos e culturais que conformaram os povos no Brasil. Porém, vale destacar que analisar os resultados que emergiram daqueles que responderam o quesito raça/cor se torna outra contribuição relevante, a fim de revelar a distribuição racial da força de trabalho em saúde no Brasil, para posteriormente buscar interferir nas políticas de gestão do trabalho na saúde, no que tange a promoção da igualdade de oportunidades e o combate ao racismo no trabalho em saúde.

5.2 PROFISSIONAIS DE SAÚDE POR RAÇA/COR E A PRESENÇA DE INDÍGENAS NA ASSISTÊNCIA À SAÚDE NO BRASIL

$\mathrm{Na}$ análise racial da força de trabalho em saúde evidenciou-se a presença de profissionais indígenas atuando na assistência à saúde, ainda que em intensa desproporção com relação à outras raças, como exposto a seguir.

A figura 3 ao trazer a proporção de profissionais de saúde na assistência desagregada por raça/cor torna clara a iniquidade racial presente no mercado de trabalho em saúde no Brasil. Nota-se que os brancos perfazem a maior parte da força de trabalho da assistência à saúde cadastrada no CNES. Considerando os 900.915 mil profissionais atuantes na assistência, os brancos, são $14,95 \%$ dessa força de Trabalho, onde estão contidos os "não declarados", o que traz o viés na interpretação do dado. Porém, ao considerar como universo de análise os 322.327 mil profissionais que preencheram o quesito raça/cor no CNES, a proporção de brancos quase triplica em comparação a última referência, representando a maioria absoluta com $41,76 \%$ da força de trabalho autodeclarada como branca, negra, 
indígena ou amarela.

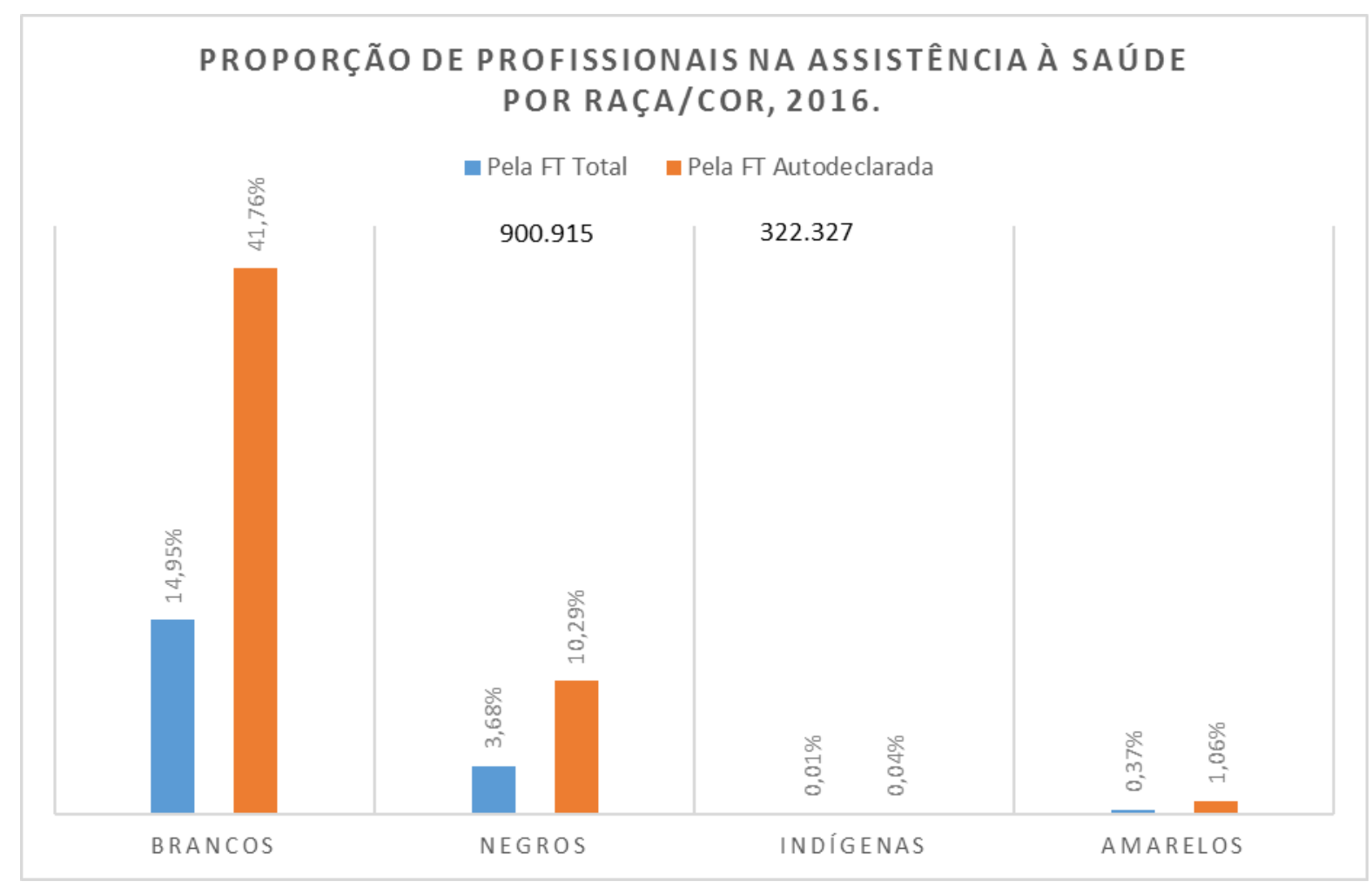

Figura 3 - Proporção de profissionais na assistência à saúde do Brasil por raça/cor, 2016. Fonte: PFTS/CNES, 2016.

A iniquidade como sequela do processo de invasão dos europeus aos territórios ancestrais, colonização, dizimação, exclusão e negação de direitos aos indígenas do Brasil é refletida nos dias atuais pela proporção ínfima de profissionais indígenas de nível superior atuantes na assistência à saúde no Brasil. Os indígenas, segundo o CNES representam $0,01 \%$ da força de trabalho total da assistência (incluindo os não declarados) e $0,04 \%$ da força de trabalho autodeclarada no CNES. A iniquidade e exclusão se estende ao povo negro que representa $3,68 \%$ da força de trabalho total e 10,29\% da FT autodeclarada, fruto também do processo histórico de sequestro do povo Africano, escravidão e exclusão ocorrido em território brasileiro.

A disparidade racial que envolve os povos indígenas no mercado de trabalho em saúde no Brasil fica ainda mais evidente ao notar que a inserção dos indígenas como trabalhadores (a) de nível superior na saúde é absurdamente desigual, desproporcional e inferior a inserção de brancos, negros e amarelos, como aponta a tabela 1. 
Tabela 1 - Diferença na proporção de Indígenas na força de trabalho da assistência à saúde em relação a Brancos, Negros e Amarelos

Proporção em relação à Proporção em relação à Força

Recorte racial

Força de Trabalho Total

\section{Indígenas versus Brancos}

Indígenas versus Negros

Indígenas versus Amarelos no CNES (900.915)

$\begin{array}{cc}1.495 \text { vezes menor } & 1.044 \text { vezes menor } \\ 368 \text { vezes menor } & 257 \text { vezes menor } \\ 37 \text { vezes menor } & 26 \text { vezes menor }\end{array}$

CNES (322.215)

de Trabalho autodeclarada no

1.044 vezes menor

26 vezes menor

Nesse rápido comparativo percebe-se com clareza que a força de trabalho no Brasil tem cor e é branca. E ainda mais, que os povos originários do Brasil ficam em sua grande maioria à margem do mercado de trabalho em saúde em relação à brancos, negros e amarelos. Constatar que os indígenas em proporção estão de 26 a quase 1500 vezes menos inseridos no mercado de trabalho em saúde do que indivíduos de outras raças impele, no mínimo, mais discussões sobre o fato, e indica a necessidade de interromper a invisibilidade dos indígenas no campo da gestão do trabalho e das políticas públicas em geral, bem como realça a urgência de recomendações e ações para compensar os danos históricos causados pelo próprio Estado aos povos indígenas do Brasil.

Poder-se-ia pensar que esse quantitativo de profissionais de saúde por raça/cor possui relação estreita com o tamanho da população de cada raça, o que é parcialmente coerente. Porém, se o fator determinante fosse unicamente a diferença populacional, os negros seriam a maioria absoluta da força de trabalho na assistência à saúde, já que representam $51,1 \%$ da população brasileira (BRASIL, 2011), confirmando com isso a desigualdade racial nesse campo, bem como na educação, já que os dados também se relacionam com o total de indivíduos que acessa as IES.

Heringer (2002), afirma que as desigualdades raciais são contundentes e facilmente visíveis no Brasil, bem como as suas consequências. Ressalta a amplitude de alcance das desigualdades raciais que afeta a inserção dos indivíduos na sociedade, prejudica a estruturação e consolidação de um país democrático com igualdade de oportunidades como se propõe no arcabouço jurídico do Brasil, apresentando-se nos diferentes ciclos e fases da vida, com destaque para as 
desigualdades raciais no acesso à educação (ou a falta dele) e sua cristalização no mercado de trabalho, gerando disparidades nos ganhos e consequentemente nas condições de vida.

Apesar da existência de recomendações e iniciativas nacionais e internacionais, conforme apresentado no capítulo 2.4 , as desigualdades raciais no mercado de trabalho são discutidas apenas considerando brancos e negros, no que tange os prejuízos da discriminação racial na inserção dos negros no mercado de trabalho, as menores remunerações recebidas pelos negros, a supremacia dos brancos que ocupam os melhores cargos e possuem as melhores remunerações, a menor qualificação profissional dos negros em comparação aos brancos, ou ainda, negros com alta qualificação ocupando lugares de menor prestígio social e remuneração desproporcional à sua qualificação, o que se mostra na contramão do que acontece com os (as) trabalhadores (as) brancos (as) (ABRAMO, 2006; TOMEI, 2005, BRASIL, 2004).

Todos estes pontos evidenciados são de fundamental importância para a discussão, levando em consideração a história de massacre, dominação e exclusão social sofrida pelo povo negro. Entretanto, o que se pretende discutir não é o mérito da questão, e sim o foco restrito e excludente com relação aos povos indígenas, principalmente considerando o Brasil como território ancestral dos povos indígenas, povos originários dessa terra. Onde se encontra a coerência da discussão das desigualdades raciais no trabalho no Brasil sem considerar os povos originários desse território, se o trabalho é um direito de cidadania?

Poder-se-ia pensar que não existem indígenas atuando no mercado de trabalho no Brasil, porém os dados aqui apresentados mostram justamente o contrário. Os indígenas estão nas universidades, estão nas agências do governo, ocupam diversos espaços de construção de conhecimento e de políticas públicas, ainda que em pequeno número, no momento. Então, o fato é que os indígenas são invisibilizados no campo teórico das produções de conhecimento, de origem governamental e acadêmica, e consequentemente no campo prático das ações de enfrentamento das desigualdades raciais no mercado de trabalho, como é o caso da lei de cotas em concursos públicos (BRASIL, 2014), que só prevê tal direito aos negros, invisibilizando, excluindo e negando o direito às medidas de ação afirmativa, que objetivam ampliar a inserção de grupos socialmente excluídos no mercado de trabalho, aos povos indígenas. 
Exemplos claros da exclusão dos indígenas das políticas públicas e das medidas de enfrentamento das desigualdades raciais no mercado de trabalho foram os dois concursos públicos realizados recentemente pela União para provimento de profissionais efetivos para atuar junto à Fundação Nacional do Índio, realizado no ano de 2016, e junto à SESAI do MS, em andamento no ano de 2017. Ambos, ancorados na Lei 12.990 de 2014 previu vagas específicas para negros, porém não ofereceu vagas específicas para indígenas. Quem melhor do que o (a) trabalhador (a) indígena para lidar com a complexidade e diversidade cultural dos povos indígenas? Esse exemplo expõe a contradição do Estado brasileiro, que por um lado apresenta propostas e discursos que defendem a igualdade de oportunidades e de direitos e que por outro lado exclui os povos indígenas de processos de inclusão no mercado de trabalho, cerceando consequentemente suas possibilidades de mobilidade social e dificultando possíveis avanços nos serviços específicos, trazidos pela inserção de profissionais indígenas em espaços institucionais de importância, como a FUNAI e a SESAI.

Heringer (2002. p. 63), apesar de também apresentar uma leitura excludente sobre as desigualdades raciais no mercado de trabalho, centrada em brancos e negros, afirma que "o Estado brasileiro, em suas diversas instâncias, ainda não demonstrou o comprometimento necessário com a diminuição das desigualdades raciais". Ressaltando ainda que a sociedade em geral, nega a raça enquanto causa da pobreza e da falta de oportunidade, sendo, portanto, um dificultador do enfrentamento das desigualdades raciais por parte da sociedade.

$\mathrm{Na}$ contramão da invisibilidade e da exclusão dos povos indígenas nos instrumentos e ações de combate à discriminação e desigualdade racial no trabalho se encontra a Agenda do Trabalho Decente para trabalhadores e trabalhadoras do SUS (ANTD-SUS), pactuada pela Mesa Nacional de Negociação Permanente do SUS (MNNP-SUS) na forma de protocolo (009/2015). Assim como a Agenda mãe vinculada a MTE, a agenda setorial da saúde vinculada ao Ministério da Saúde, se propõe a promoção do trabalho decente no SUS, contendo como importante acréscimo a inclusão dos indígenas como foco da Agenda no que tange o combate à discriminação racial e promoção de igualdade de oportunidade e tratamento no trabalho, citados na linha estratégica que prevê:

Fortalecer as ações para incentivo e garantia da progressão funcional de mulheres, negros, indígenas e outros segmentos discriminados no SUS, criando mecanismos de identificação e enfrentamento das dinâmicas de 
discriminação que ferem o princípio da igualdade de oportunidades e tratamento no emprego (BRASIL, 2015. p. 9).

Vale ressaltar que apesar da ANTD-SUS incluir os indígenas em uma de suas quatro prioridades centrais, "combater todas as formas de discriminação no local de trabalho, com atenção às discriminações de gênero, raça e etnia" (BRASIL, 2015. p. 5), a sua implementação em âmbito nacional, estadual e municipal ainda não é realidade, estando no campo das ideias e intenções. Sua implementação para a promoção da igualdade de oportunidade e tratamento, bem como para o combate à discriminação racial, no que tange os (as) trabalhadores (as) indígenas, deve ter especial atenção nos estados e municípios onde existem conflitos relacionados aos territórios indígenas, e consequentemente, onde os índices de mortalidade por causas externas e de violências diversas são alarmantes, a exemplo dos estados de Mato Grosso do Sul e da Bahia (FERREIRA, MATSUO, SOUZA, 2011; BASTA, ORELLANA, ARANTE, 2012; CAPIBERIBE, BONILLA, 2015).

A falta de igualdade de oportunidades no mercado de trabalho e na formação dos povos indígenas se expressa na diferença proporcional de indígenas de nível superior no mercado de trabalho em saúde, como anteriormente apresentada. Esta realidade confirma a ocorrência de um processo histórico intenso de negação de direitos, que se depara numa reflexão importante sobre o trabalho como direito social, e consequentemente sobre a real cidadania dos povos indígenas no Brasil. Explorar a inserção do indígena no mercado de trabalho em saúde e constatar exclusão, disparidade, iniquidade e diferentes oportunidades entre os povos indígenas, brancos, negros e amarelos é questionar a cidadania no Brasil. Cidadania para quem? Direitos para quem? Se os indígenas sequer possuem visibilidade nas políticas e nas discussões sobre a temática.

\subsection{INDÍGENAS NO ENSINO SUPERIOR NO BRASIL}

Traçar um debate sobre a inserção dos profissionais indígenas na assistência à saúde no Brasil alienado da discussão da formação de indígenas no ensino superior seria no mínimo incoerente. Por isso, é de suma importância considerar as diferenças de oportunidades de formação existentes entre brancos, indígenas, 
negros e amarelos, ressaltando o prejuízo histórico que os povos indígenas e o povo negro sofreram e sofrem nesse território.

Destaca-se que as lacunas existentes na formação e as constantes iniquidades envolvendo os povos indígenas impulsionou o movimento indígena a buscar a abertura dos espaços institucionais de formação profissional para os povos indígenas, como bem retrata o exemplo das universidades. É notável a crescente presença de indígenas nas universidades não-indígenas do país, tendo aumento importante após a lei de cotas, lei oㅜ 12.711/2012 e decreto № 7.824, ambos de 2012 (BRASIL, 2012), já sendo bem descrita na literatura científica (AMARAL, BAIBICHFARIA, 2012; LIMA, 2012; GARLET, GUIMARÃES E BELLINI, 2010; SILVA, MARQUES, 2016).

O Censo do Ensino Superior revelou a presença de mais de 32 mil indígenas no ensino superior no ano de 2015, considerando todas as grandes áreas de conhecimento, inclusive a saúde. Para além da constatação da presença de indígenas nas Instituições de Ensino Superior nos dias atuais, é necessário explorar o seu aumento significativo ocorrido ao longo dos últimos 5 anos. Os dados do Instituto Anísio Teixeira comprovam tal fato, por meio dos censos do ensino superior, que a partir de 2011 apresentaram o quantitativo de matriculados em IES desagregados por raça e cor.

A figura 4 mostra a série histórica dos indígenas matriculados em IES, de 2010 a 2015, considerando todas as grandes áreas de conhecimento.

\section{INDÍGENAS MATRICULADOS EM IES}

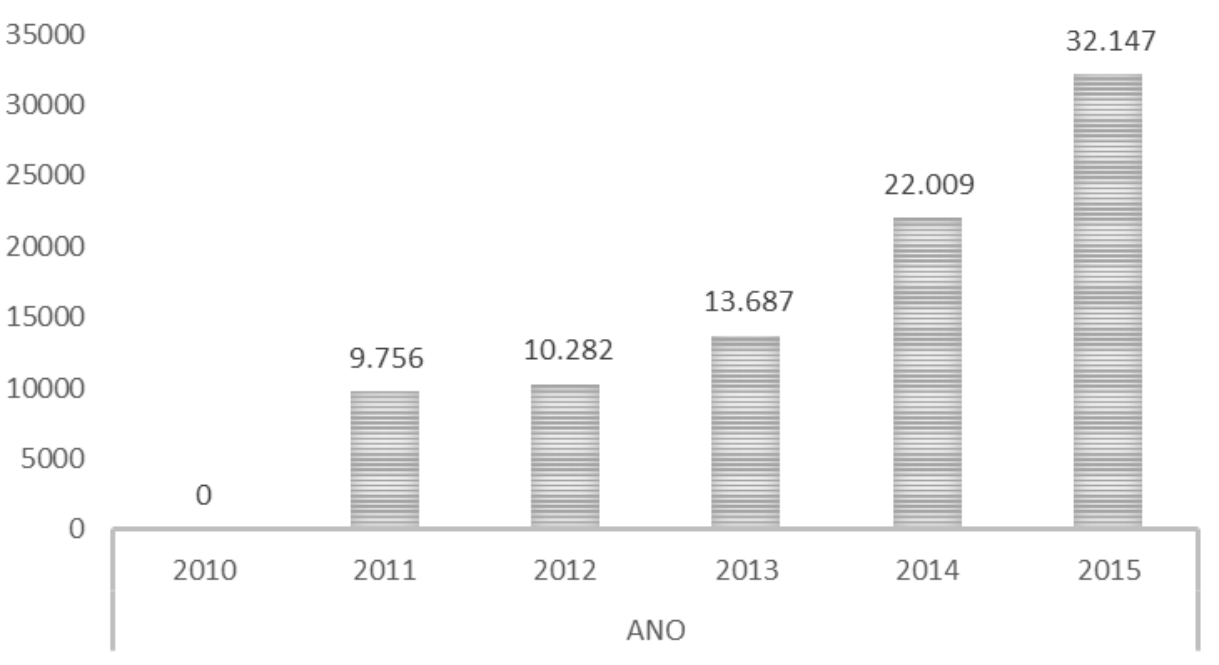

Figura 4 - Série histórica com quantitativo de indígenas matriculados em IES, de 2010 a 
2015, no Brasil.

Fonte: INEP, 2016.

Nota-se que a presença de indígenas no ensino superior apresenta tendência de expansão progressiva, com taxa de crescimento percentual de $229,5 \%$ no período, tendo elevação mais significativa nos anos de 2014 e 2015 . Essa ascendência se apresentou em todas as regiões do país no período de 2011 a 2015, com destaque para as regiões norte, centro-oeste e nordeste com taxas de crescimento de $307,1 \%, 302,3 \%$ e $236,9 \%$, respectivamente. Apesar das taxas percentuais de crescimento apontarem este resultado, a região nordeste possuía em 2015 o maior número absoluto de matriculados indígenas (9.307). Diante disto, pode-se inferir que políticas de ação afirmativa, como por exemplo, a lei de cotas, criada em 2012, tenha apoiado a inserção de estudantes indígenas no ensino superior no Brasil.

Porém, apesar desta inserção se apresentar crescente ainda é insuficiente diante da exclusão e marginalização histórica sofrida pelos povos indígenas. A magnitude dessa disparidade racial na formação se torna clara ao se constatar que indígenas, no ano de 2015, representaram apenas $0,4 \%$ do total de matriculados em IES no Brasil, os brancos $36,16 \%$, os negros $27 \%$ e os amarelos $1,44 \%$ (BRASIL, 2015). Esses dados são substanciais para a comprovação da desigualdade racial que envolve os indígenas brasileiros, que tem a menor participação em IES quando comparado com outros grupos étnico raciais, evidenciando as disparidades de oportunidades na formação, o que consequentemente irá reverberar no total de força de trabalho disponível para atuar na assistência à saúde.

Segundo Lima (2012, p. 175), a presença dos indígenas no ensino superior mostra a movimentação em direção à qualificação, refletindo a necessidade dos povos indígenas de entender e dominar a "avassaladora entrada das políticas públicas nas aldeias indígenas". É considerada pelo autor como um "novo regime de poder marcado pela presença dos indígenas nas agências do Estado brasileiro, onde "os intelectuais indígenas buscam adquirir a capacidade de extrapolar seus contextos e formular interpretações em diálogo com outros contextos locais e regionais, nacionais e internacionais, sobre as relações entre povos indígenas e Estado".

Garlet, Guimarães e Bellini (2010) alertam para a insuficiência da garantia de vagas específicas no ensino superior, por meio de cotas, se antes não melhorar a 
qualidade da educação básica, pois sem isso os indígenas teriam menores condições de usufruir do direito de estar numa universidade. Essa contribuição dos autores aponta para a importância de uma discussão ampliada que alie as dimensões de inserção e permanência dos indígenas nas instituições de ensino superior, e com isso a reflexão sobre os fatores que fortalecem e fragilizam a aprovação nos cursos de graduação e a sua conclusão.

A existência de inúmeras dificuldades referentes à permanência dos povos indígenas no ensino superior não-indígena tem sido descrita por Amaral e BaibichFaria (2012), Lima (2012) e Silva e Marques (2016). Isto demonstra que algumas discussões que cercam a formação indígena (em saúde ou em outras áreas) não se detêm e/ou não se deve deter à dimensão da inserção, tomando maior coerência ao considerar e valorizar a complexidade que cerca o "ser indígena" no Brasil.

Dificuldade de pertencimento acadêmico, desânimo em continuar estudando, desejo de permanecer nas aldeias de origem e a frágil educação escolar básica são relatadas como limites para a permanência dos indígenas na educação superior. Os autores ressaltam ainda que por mais que o discurso seja de uma provável troca intercultural, nas universidades esse movimento raramente é de mão dupla, restando a visão de que "os indígenas parecem, para a academia, não ter nada sabido ou a ensinar" (AMARAL, BAIBICH, 2012. p. 826), o que já evidencia os preconceitos sofridos pelos estudantes indígenas nos espaços não-indígenas de formação.

Lima (2012) corrobora com os autores, quando afirma que, pelo paradigma hegemônico, a ciência e a cultura são patrimônios exclusivos da universidade. Essa supremacia do saber ocidental moderno sobre o saber tradicional trazido e representados pelos alunos universitários indígenas revela o racismo institucional enraizado nas universidades, a invisibilidade e subestimação da intelectualidade indígena quando comparado aos não-indígenas e a não-aceitação da pluralidade cultural representada por esses estudantes.

Silva e Marques (2012) corroboram com Amaral e Baibich (2012) e acrescentam aos entraves que interferem na permanência dos alunos indígenas na universidade: as dificuldades financeiras para se manter em outras cidades, distância da família, mudanças pedagógicas provocadas pelo contato com o ensino não-indígena, mudanças psicológicas, físicas e emocionais, gerando adoecimento, déficit no aprendizado, chegando até ao abandono do curso. Assim, é nítido que todos esses fatores precisam ser profundamente analisados e reconhecidos, até 
provocarem mudanças de ordem estrutural e ideológica na universidade.

Lima (2012) chama atenção para o nível primário de reflexão sobre o acesso de indígenas, sua permanência, sucesso ou fracasso em cursar e finalizar um curso em IES, trazendo com isso barreira importante para o alcance de uma capacitação técnico-política e/ou inserção profissional que funcione conectada com as identidades indígenas. Desta forma cabem as seguintes reflexões: Como o tipo de formação dos indígenas pode potencializar ou fragilizar seu perfil profissional para atuação na assistência à saúde? A pluralidade étnica pode contribuir para o enriquecimento das práticas de saúde voltadas para o cuidado da população?

Seria assertivo diluir as especificidades socioculturais dos povos indígenas na formação e na sua atuação no mercado de trabalho em saúde, em prol de um único saber que aponta para a homogeneização dos profissionais de saúde? Vale destacar a relevância do diálogo intercultural como instrumento potente para a formação de profissionais com perfil adaptado para atuar na saúde pública, para o enriquecimento do sistema de saúde oficial, e para o cuidado holístico na assistência à saúde no Brasil.

\subsection{PROFISSIONAIS INDÍGENAS POR CATEGORIA PROFISSIONAL E LOCALIZAÇÃO GEOGRÁFICA}

A frequência absoluta de profissionais indígenas atuantes na assistência à saúde exposta na figura 5, ilustra a distribuição de indígenas nas 14 (quatorze) profissões de saúde. Considerando que a Medicina, a Enfermagem e a Odontologia ocupam o lugar de maioria na força de trabalho na assistência à saúde no Brasil, são atualmente as categorias que mais incorporaram profissionais indígenas. Destaca-se a Enfermagem como a profissão de saúde que mais apresenta indígenas inseridos na assistência à saúde e cadastrados no CNES (50 indígenas). A Medicina se aproxima desse quantitativo, com 46 Médicos indígenas incorporados à assistência. 


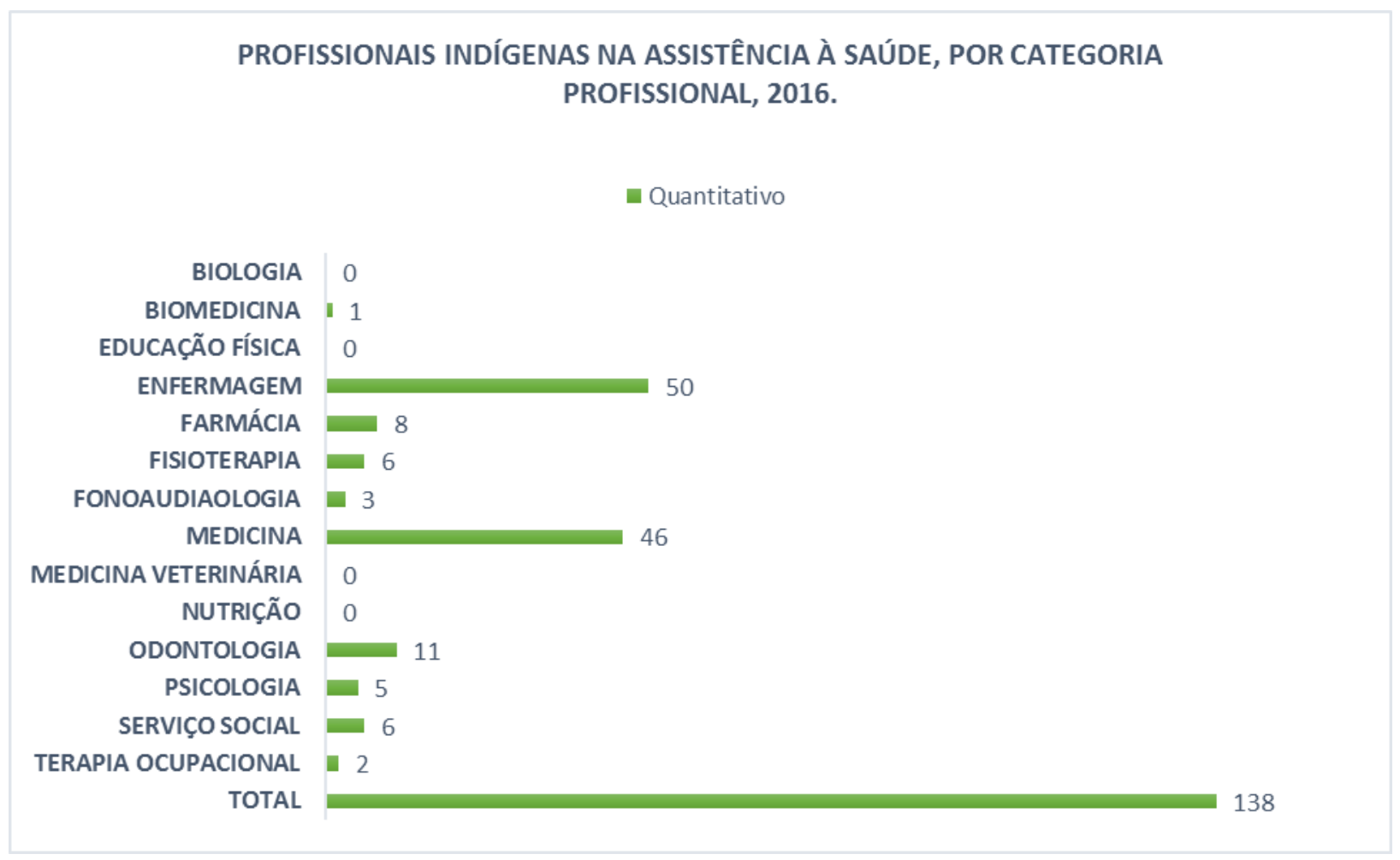

Figura 5 - Profissionais indígenas na assistência à saúde, desagregada por categoria profissional, 2016.

Fonte: PFTS/CNES, 2016.

Maria Helena Machado et al (2016) também identificaram indígenas na enfermagem corroborando com o achado do presente estudo no que se refere à comprovação da existência de indígenas de nível superior na saúde, porém os quantitativos apresentaram-se distantes do total de enfermeiros indígenas apresentados pela PFTS/CNES. A pesquisa do perfil da enfermagem no Brasil aponta a presença de 10 mil profissionais indígenas na enfermagem com cadastro ativo no COFEN. Destes 1.100 são enfermeiros (10\%) e 8.900 são técnicos e auxiliares (90\%). A maioria absoluta dos (as) enfermeiros (as) (nível superior) é branca $(57,9 \%), 31,1 \%$ pardos, $6,6 \%$ pretos, $2,5 \%$ amarelos e $0,3 \%$ indígenas (MACHADO et al, 2016). Apesar da relevância dos achados apresentados como "características gerais da enfermagem" em artigo próprio (MACHADO et al, 2016. p.9), esses dados não foram problematizados, ao menos no sentido de estimular a discussão acerca das desigualdades raciais entre as enfermeiras e enfermeiros brasileiros.

A composição racial evidenciada por Machado et al (2016) também não foi incluída como aspecto transversal nas análises realizadas sobre a formação, 
mercado de trabalho e condições de trabalho da enfermagem, exceto na investigação de situações de discriminação no trabalho. Foi revelado que $25,3 \%$ dos profissionais da enfermagem relataram já ter sofrido discriminação de ordem racial no ambiente de trabalho, o que representou $21,6 \%$ dos profissionais de nível superior e 26,2\% dos técnicos e auxiliares. Os achados sobre discriminação racial sofrida pelos profissionais da enfermagem também não foram problematizados no artigo intitulado "condições de trabalho da enfermagem" (MACHADO et al, 2016. p. 63). Sendo assim, os (as) autores (as) trouxeram à tona a presença de profissionais indígenas de nível superior na enfermagem, o que corrobora com os achados do presente estudo.

$\mathrm{Na}$ análise da distribuição das profissões de saúde, evidenciou-se que a mesma se apresenta diferenciada entre as regiões geográficas, como exposto nas figuras 6,7 e 8. A Enfermagem possui maior quantitativo de indígenas na região Sudeste, seguido das regiões Centro-Oeste e Nordeste. Já a Farmácia e a Fisioterapia têm o Sudeste como região de destaque.

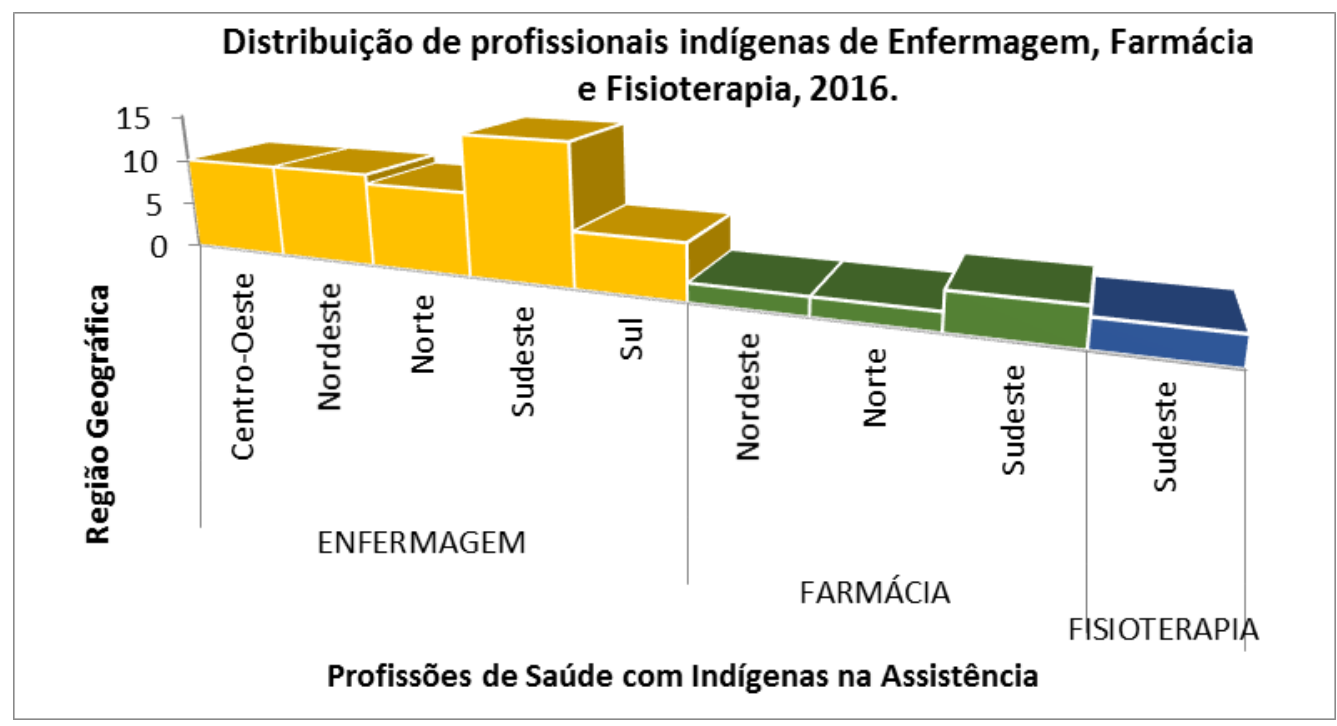

Figura 6 - Distribuição de profissionais indígenas de Enfermagem, Farmácia e Fisioterapia, desagregadas por região geográfica, 2016. Fonte: PFTS/CNES, 2016.

A psicologia e o Serviço social possuem maior frequência absoluta de indígenas na região sudeste, já a Terapia Ocupacional não teve sua distribuição regional identificada pela PFTS (figura 7), sendo este um fator já identificado como limitação do estudo. 


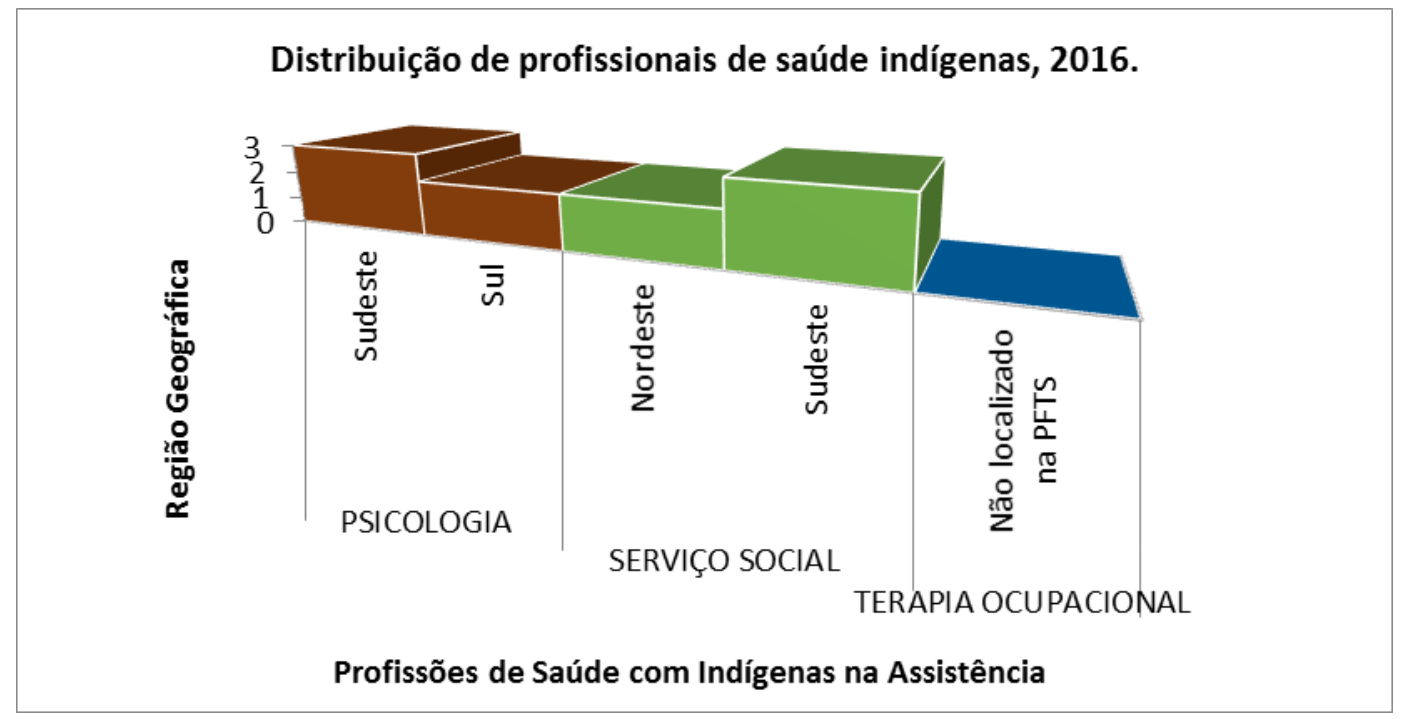

Figura 7 - Distribuição de profissionais indígenas de Psicologia, Serviço Social e Terapia Ocupacional, desagregadas por região geográfica, 2016.

Fonte: PFTS/CNES, 2016.

A figura 8 aponta que a Medicina apresentou distribuição de indígenas maior na região Sudeste, sendo seguida pela Centro-Oeste e a Odontologia teve predominância de indígenas na região Sul. Vale ressaltar que a fonoaudiologia também não teve a distribuição regional de indígenas sinalizada pela PFTS, o que inviabilizou tal levantamento.

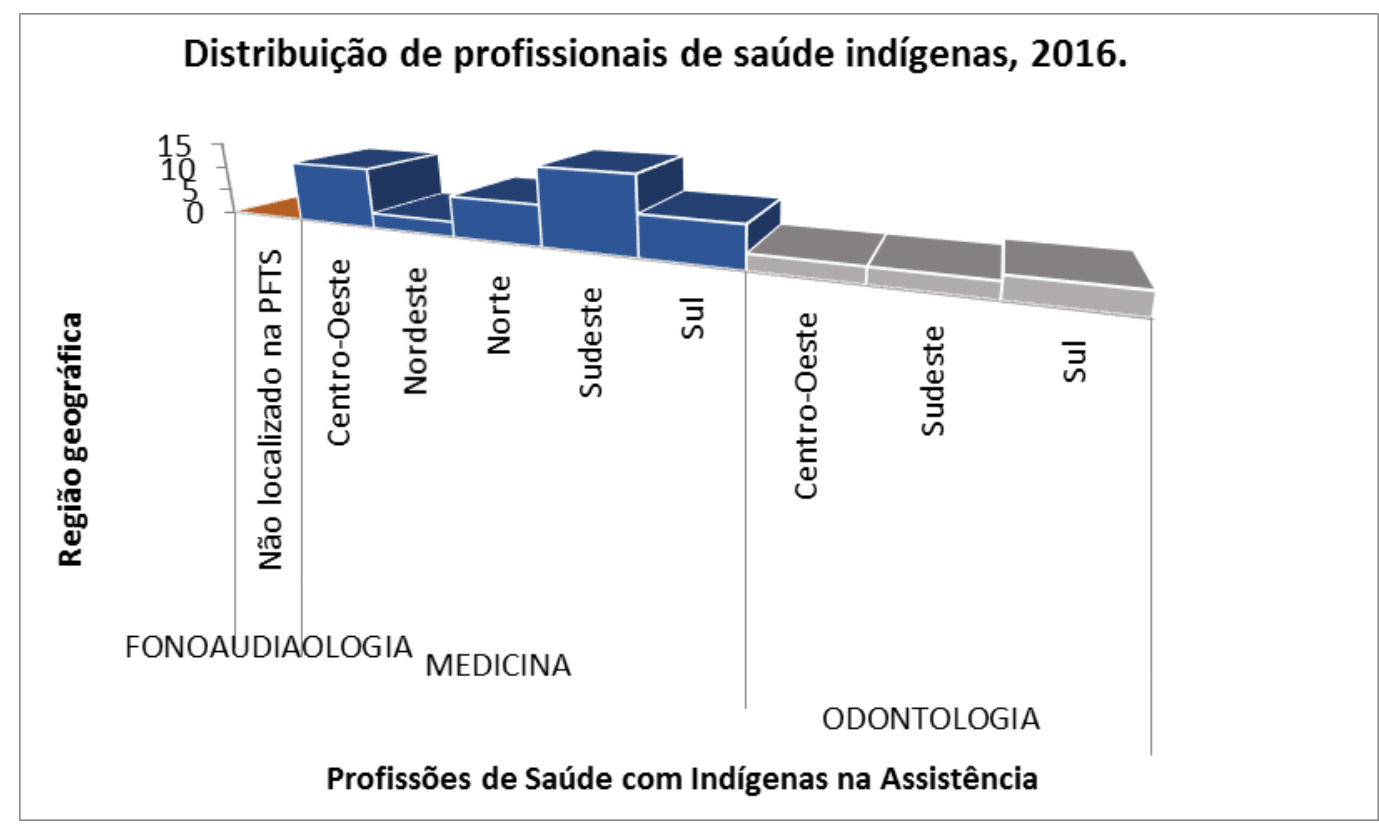

Figura 8 - Distribuição de profissionais indígenas de Fonoaudiologia, Medicina e Odontologia, Fonte: PFTS/CNES, 2016. desagregadas por região geográfica, 2016. 
Assim, diante do exposto nos gráficos 6, 7 e 8 fica evidente que a maioria absoluta dos profissionais indígenas atuantes na assistência à saúde no ano de 2016 estava na região sudeste, tendo a enfermagem, a farmácia, a fisioterapia, a psicologia, o serviço social e a medicina predominância de indígenas nessa região. Tal diferencial pode encontrar explicação no fato da região sudeste apresentar os maiores índices de egressos das 14 áreas da saúde, maior quantidade de cursos de Medicina (concentrava entre 2000 e 2011 mais de 54\% do total de vagas em Medicina), Enfermagem e Odontologia e concentrar a maior parte dos profissionais de saúde, como afirmam Dal Poz, Pierantoni e Girardi (2013). Cordeiro (1997) acrescenta à reflexão o fato do sudeste ser a região que mais concentra gastos em saúde, juntamente com a região sul. Dessa forma, torna-se inegável a característica peculiar da região sudeste como importante polo de formação e captação de profissionais de saúde.

Ao analisar a distribuição de indígenas por unidade da federação, nota-se que o estado que mais concentra profissionais indígenas é São Paulo, sendo seguido por Rio de Janeiro, Paraná, Distrito Federal (com a mesma quantidade de profissionais indígenas em $2^{ }$lugar), Bahia (em $3^{\circ}$ lugar), Tocantins e Mato grosso do Sul (ambos em 4ํlugar), como mostra a figura 9.

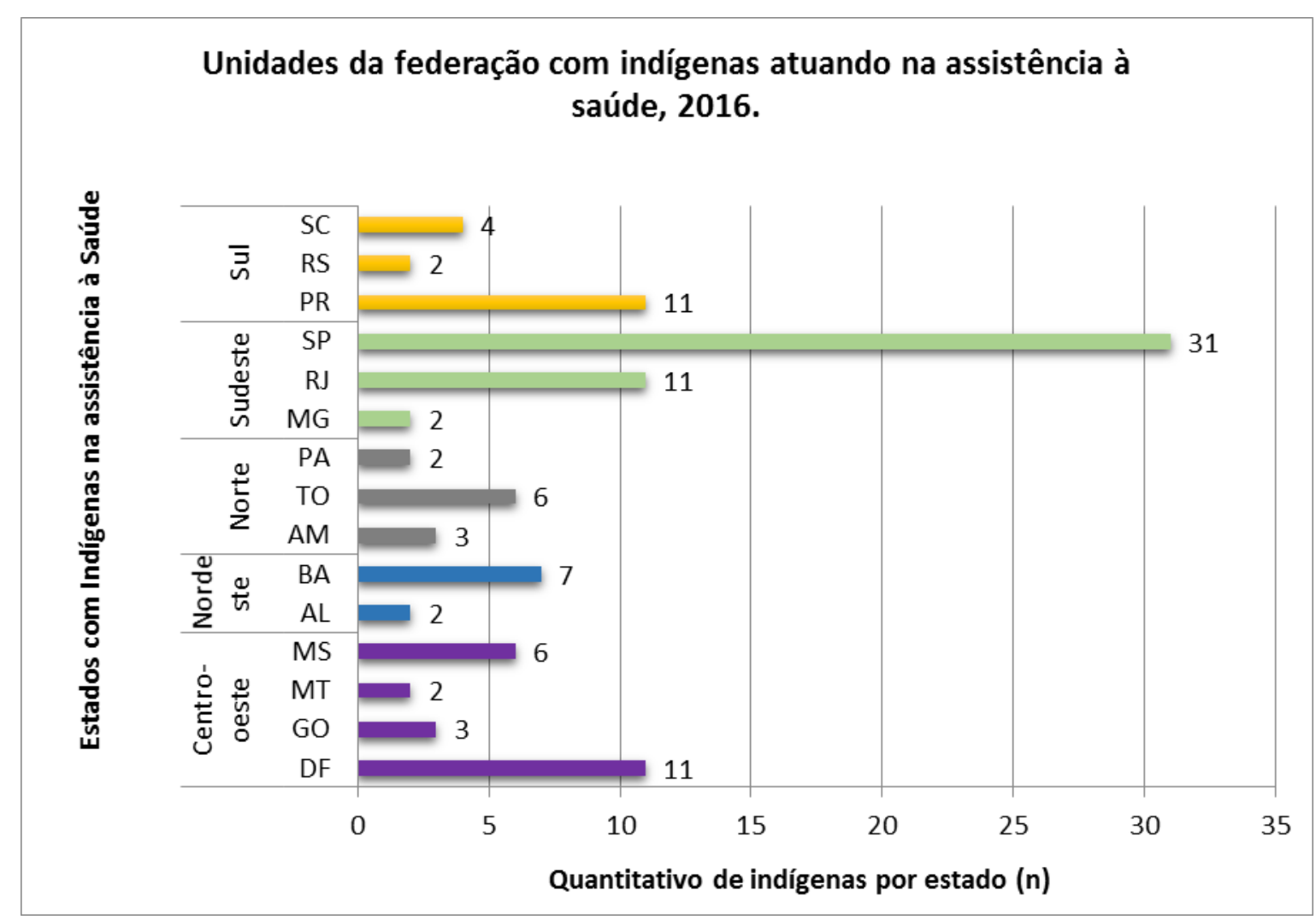


Figura 9 - Presença de profissionais indígenas atuantes na assistência por Unidade da Federação, 2016.

Fonte: PFTS/CNES, 2016.

Esses dados ganham significado ao analisar três fatores: A distribuição dos povos indígenas no Brasil, a quantidade de indígenas matriculados em IES e por último, as áreas já conhecidas de conflito entre indígenas e não-indígenas. Esses fatores são de extrema relevância para compreender o que significa ter profissionais indígenas nos estados em questão. Como pensar a gestão dos (as) trabalhadores (as) indígenas da assistência à saúde sem conhecer a realidade que os acompanha? Sendo assim, para ajudar na compreensão dessa distribuição são apontadas algumas questões relevantes à reflexão sobre as especificidades que envolvem os (as) trabalhadores (as) indígenas, tendo como variante a sua inserção geográfica.

A tabela 2 aponta aspectos demográficos, de formação e de conflitos referentes aos estados que possuem maior quantitativo de profissionais indígenas atuando na assistência à saúde no Brasil, especificamente São Paulo, Rio de Janeiro, Paraná, Distrito Federal, Bahia, Tocantins e Mato Grosso do Sul. Destaque deve ser dado a relevância de analisar o contexto que envolve os indígenas que atuam como profissionais nos estados foco de conflitos e situações de violências, como apontado nos capítulos 2.1 e 2.2. Esses fatores são imprescindíveis para a tomada de decisão e elaboração de políticas e ações de gestão do trabalho com foco no combate ao racismo e as desigualdades raciais.

O Relatório da Violência contra os povos indígenas no Brasil, produzido anualmente pelo Conselho Indigenista Missionário (CIMI) revelou que no ano de 2015 foram registrados 18 conflitos relacionados à direitos territoriais, dentre os estados foco dos conflitos encontram-se o Mato Grosso do Sul e a Bahia, ambos com indígenas atuando na assistência à saúde, conforme apresentado na tabela 2. Segundo os dados, o Mato Grosso do Sul sofreu em menos de um ano dez ataques aos territórios indígenas dos povos Guarani e Kaiowá, Nhandeva e Terena, sendo que muitos deles tinham duração de dias. Foram registrados casos de tortura física, pessoas vítimas de ataques por arma de fogo, destruição do acampamento por conta de incêndio criminoso, violência contra a gestante e contra rezadores (CIMI, 2015). 
Tabela 2 - Aspectos demográficos, de inserção acadêmica, caracterização étnica e identificação de conflitos nos estados com maior força de trabalho indígena.

\begin{tabular}{|c|c|c|c|c|c|c|}
\hline \multicolumn{2}{|c|}{$\begin{array}{l}\text { ESTADOS COM } \\
\text { MAIOR FORÇA } \\
\text { DE TRABALHO } \\
\text { INDÍGENA }\end{array}$} & \multirow[t]{2}{*}{$\begin{array}{l}\text { POPULAÇÃO } \\
\text { INDÍGENA NO } \\
\text { ESTADO }\end{array}$} & \multirow[t]{2}{*}{$\begin{array}{l}\text { INDÍGENAS } \\
\text { MATRICULADOS } \\
\text { EM IES (2015) }\end{array}$} & \multirow[t]{2}{*}{$\begin{array}{c}\text { ETNIAS RESIDENTES } \\
\text { NO ESTADO }\end{array}$} & \multicolumn{2}{|c|}{$\begin{array}{l}\text { SITUAČÃO DE } \\
\text { VIOLÊNCIA } \\
\text { E/OU CONFLITO } \\
\text { DIVULGADA }\end{array}$} \\
\hline Estados & $\mathbf{N}$ & & & & Sim & Não \\
\hline SP & 31 & 41.794 & 4.983 & $\begin{array}{c}\text { Tupi Guarani; } \\
\text { Guarani; } \\
\text { Guarani Mbya; } \\
\text { Guarani Nandeva; }\end{array}$ & $x$ & \\
\hline RJ & 11 & 15.894 & 2.229 & $\begin{array}{c}\text { Guarani Mbya; } \\
\text { Guarani Nhandeva; }\end{array}$ & & $x$ \\
\hline PR & 11 & 25.915 & 617 & $\begin{array}{c}\text { Guarani; } \\
\text { Avá-Guarani; } \\
\text { Guarani Nhandeva; } \\
\text { Guarani Mbyá } \\
\text { Xetá; } \\
\text { Kaingang; }\end{array}$ & $x$ & \\
\hline DF & 11 & 6.128 & 751 & Vários povos & $\mathrm{X}$ & \\
\hline BA & 7 & 56.381 & 1.249 & $\begin{array}{c}\text { Pataxó; } \\
\text { Pataxó Hã hã hãe } \\
\text { Payaya; } \\
\text { Tupinambá; } \\
\text { Xakriabá; } \\
\text { Tuxá; } \\
\text { Tumbalalá; }\end{array}$ & $x$ & \\
\hline TO & 6 & 13.131 & 364 & $\begin{array}{c}\text { Kanela; } \\
\text { Krahô-Kanela; } \\
\text { Apinajé; } \\
\text { Javaé; } \\
\text { Avá-Canoeiro; } \\
\text { Karajá; }\end{array}$ & $x$ & \\
\hline MS & 6 & 73.295 & 1.151 & $\begin{array}{c}\text { Guarani; } \\
\text { Guarani e Kaiowá; } \\
\text { Guarani M'Bya; Guarani- } \\
\text { Nhandeva; } \\
\text { Terena } \\
\text { Ofayé-Xavante }\end{array}$ & $x$ & \\
\hline
\end{tabular}

Fonte: Conselho Indigenista Missionário (CIMI), 2015; INEP, 2015; PFTS, 2016.

Na Bahia o território Tupinambá sofreu incêndio criminoso, com a destruição de duas casas e parte de uma plantação por queimada. Ressalta-se que as investidas violentas contra a comunidade Tupinambá se tornaram mais frequentes a partir de 2013 quando estudos de delimitação territorial da área foram publicados (CIMI, 2015).

São Paulo, Tocantins e Mato grosso do Sul aparecem entre os estados que sofreram invasão possessória, exploração ilegal de recursos naturais e danos diversos ao patrimônio, totalizando no ano de 2015 cinquenta e cinco casos. As ocorrências mais frequentes são: invasões, desmatamento, destruição de patrimônio, exploração ilegal de recursos naturais, contaminação de rios, queimadas 
e incêndios, caça ilegal, contaminação por agrotóxico, dentre outras (CIMI, 2015).

Dados oficiais referentes aos assassinatos de indígenas no Brasil revelaram o total de 137, destes 36 foram de indígenas do Mato Grosso do Sul. Analisando o período de 2003 a 2015, foram registrados 891 assassinatos de indígenas no Brasil, sendo 426 no estado do Mato Grosso do Sul, tornando-o o estado mais violento e que mais assassina indígenas no Brasil. Segundo levantamento do CIMI, os estados de Mato Grosso do Sul, Bahia, Tocantins e Paraná tiveram casos de assassinatos de indígenas no ano de 2015, sendo respectivamente das etnias Guarani e Kaiowá e Guarani Nhandeva, Tupinambá e Tumbalalá, Apinajé, Karajá, Krahô, Xerente, Guarani e Kaingang (CIMI, 2015).

Evidenciar o cenário de violências sofridas pelos povos indígenas no Brasil, com ênfase nos estados que possuem força de trabalho indígena atuante na assistência à saúde se faz imprescindível para balizar as discussões sobre o (a) trabalhador (a) e o trabalho indígena na saúde. Esses pontos trazem à tona algumas das especificidades que cercam o trabalhador indígena da saúde, como por exemplo o risco iminente de morte em alguns estados do país, como é o caso do Mato Grosso do Sul e da Bahia e as situações diversas de discriminação e racismo sofridos em meio à sociedade em geral.

Então, como fazer a gestão de trabalhadores e trabalhadoras indígenas que residem em estados com a presença de conflito territorial, violência, perseguição de ordem racial e desrespeito cultural? O que fica de reflexão para o campo das políticas públicas de saúde e para a gestão do trabalho? Seria semelhante fazer a gestão do trabalho de profissionais de saúde brancos, negros e indígenas?

Vale pôr relevo na importância de considerar o contexto sócio histórico e cultural que explica a complexidade da vida indígena no Brasil, como apresentado no capitulo 2.1. As particularidades no pensar, organizar-se e agir no mundo não estão evidenciadas na literatura científica, talvez por isso não ganhem a centralidade das discussões. Porém muitas dessas singularidades tornam-se nítidas com a simples análise do contexto apresentado neste estudo. Pensar políticas públicas que tenham o foco na gestão do trabalho na saúde exige considerar as singularidades que formam os (as) trabalhadores (as), e nesse caso especifico, os (as) trabalhadores (as) indígenas. 


\subsection{FORÇA DE TRABALHO INDÍGENA EMPREGADA NA SAÚDE INDÍGENA}

A figura 10 abre a análise sobre a força de trabalho indígena empregada na assistência da área específica de saúde indígena, ligada à Secretaria Especial de Saúde Indígena do Ministério da Saúde. Segundo Ferreira, Portillo e Nascimento (2013) a criação da SESAI, legalizada pelo Decreto o 7.336 de 2010, representou a transferência da gestão do Subsistema de saúde indígena da Funasa para o Ministério da Saúde, marcando uma nova etapa na Política Nacional de Atenção à Saúde dos Povos indígenas e na relação destes com o Estado.

Assim sendo, a saúde indígena é o próprio Subsistema de Atenção à Saúde Indígena que se apresenta como parte constituinte do Sistema Único de Saúde. Segundo Ferreira, Portillo e Nascimento (2013), o subsistema visa atender ao princípio da equidade, adequando o SUS à diversidade da população brasileira, especificamente dos povos indígenas que residem em aldeias, por meio de serviços de saúde diferenciados, com configuração e estruturação próprias.

A Saúde Indígena atualmente sob gestão do Ministério da Saúde, por meio da SESAI, se ocupa do atendimento exclusivo aos povos indígenas, a partir de estrutura de funcionamento organizada sob a forma de Distritos Sanitários Especiais Indígenas, que conformam redes territorializadas de serviços. Toda a estruturação da saúde indígena, com seus 34 DSEls, visa responder aos propósitos da Política Nacional de Atenção à Saúde dos Povos Indígenas que se mantém no intuito de assegurar o acesso à atenção integral à saúde (PONTES, STAUFFER, GARNELO, 2012).

Vinculado aos DSEI, no âmbito estrutural e organizacional das ações e serviços de saúde tem-se os postos de saúde nas aldeias, que funcionam ofertando serviços de atenção primária à saúde, os pólos-base, que se configuram como unidades mais complexas que reúnem os profissionais de saúde atuantes no território indígena, as Casas de Apoio ao Índio (CASAI), que se destinam à apoiar a referência dos indígenas para os serviços de média e alta complexidade, situados fora das aldeias (PONTES, STAUFFER, GARNELO, 2012). Assim, todas essas unidades que ofertam os serviços de saúde indígena são também postos de trabalho para os (as) profissionais de saúde. 
Os dados disponibilizados pela SESAI/MS, apontam força de trabalho de nível superior atuante na Saúde Indígena total de 4.331 trabalhadores (as), no ano de 2016, não sendo disponibilizado pelo nível central de gestão do subsistema de saúde indígena a composição racial dessa FT. Nota-se que a maior parte da FT de nível superior da saúde indígena é formada por Enfermagem, em 1o lugar, Odontologia em $2^{\circ}$ lugar e Medicina em $3^{\circ}$, considerando as 14 (quatorze) profissões de saúde, e no caso específico da saúde indígena foi também considerada a função de educador em saúde, já que apresenta-se como função de profissionais de saúde de nível superior (BRASIL, 2015) (Figura 10).

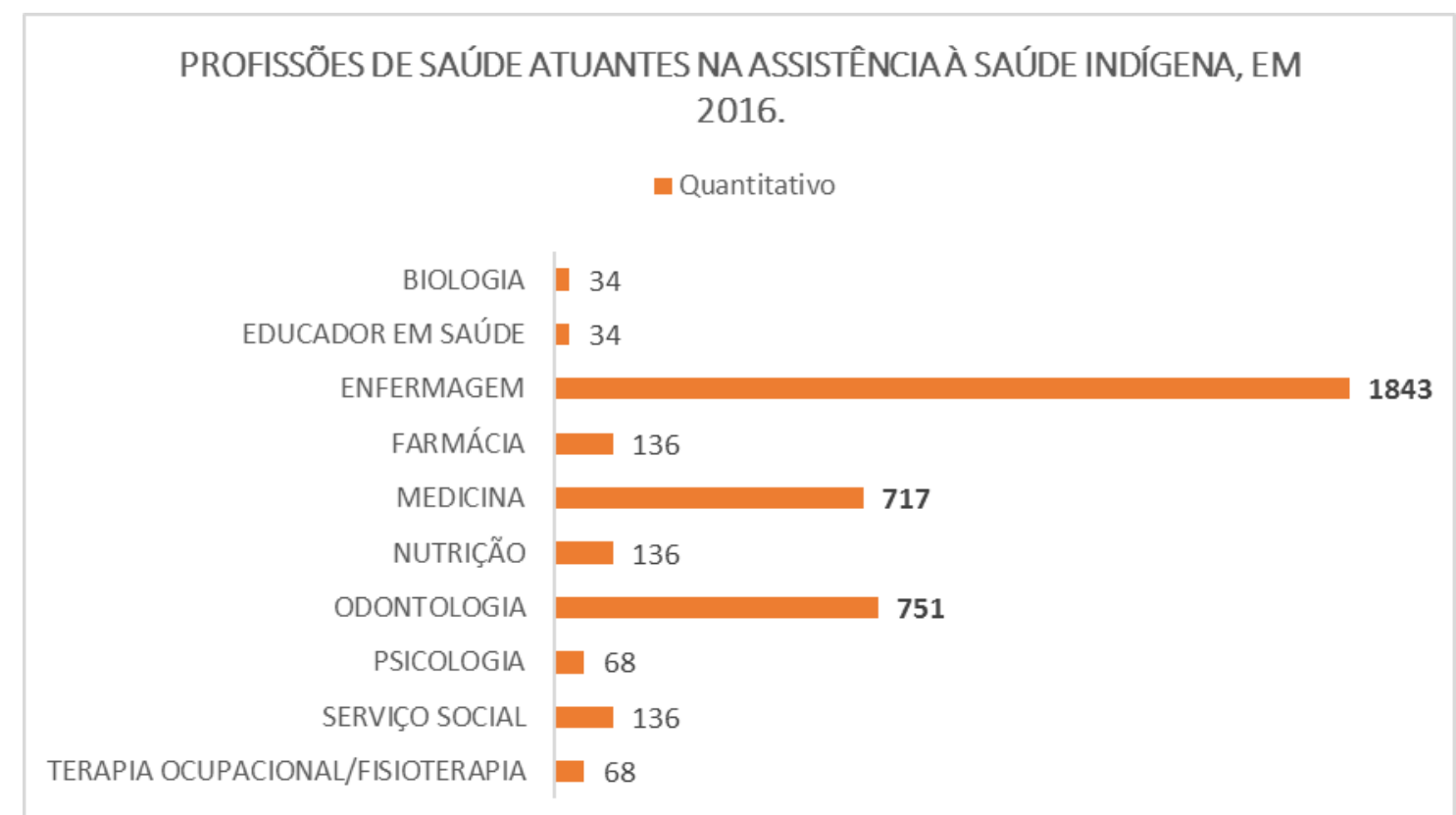

Figura 10 - Profissionais das 14 profissões de saúde, segundo o CNS, atuantes na assistência à Saúde Indígena, em 2016.

Fonte: SESAI/MS, 2016.

Segundo dados informados pela SESAI/MS outras categorias profissionais de nível superior também fazem parte da força de trabalho da Saúde Indígena, apesar de não terem sido incluídas na pesquisa, como por exemplo, antropólogos, engenheiros, arquitetos, geólogos, epidemiologistas, especialistas em saúde pública, dentre outros (BRASIL, 2015). Vale a pena ressaltar que por se tratar de contextos de grande complexidade, a inserção de profissionais de outros campos do saber que extrapolem a visão biológica se torna essencial e estratégico.

Os Agentes Indígenas de Saúde e os Agentes Indígenas de Saneamento (AISAN) atuam nos postos de saúde dentro das aldeias, já nos pólos-base, Equipes 
Multidisciplinares de Saúde Indígena (EMSI) possuem inserção, acompanhando a formação da equipe mínima também realizada nos serviços não indígena, caracterizado pela atuação da Enfermagem, Odontologia, Técnicos de Enfermagem e Odontologia, AIS e AISAN. As diversas profissões que conformam a área da saúde podem ter inserção na saúde indígena, nos Núcleos de Apoio à Saúde Indígena (NASI), a depender da escolha dos DSEIS, baseados em critérios epidemiológicos e outros (PONTES, STAUFFER, GARNELO, 2012).

Garnelo (2012) chama atenção para o momento adverso em que se deu a constituição do Subsistema de Saúde Indígena, que por um lado encontrava oportunidade política para se instituir, e por outro lado tinha a política neoliberal que pregava a participação mínima do Estado nas políticas sociais, onde se encontra a política de saúde. Nesse mesmo período o SUS movimentava-se para transferir a execução das ações de saúde aos municípios, tornando o governo federal mais distante, supervisor e financiador. A autora ressalta que era priorizado na época a compra de serviços de entidades privadas voltados à prestação de serviços, como os da saúde, diminuindo a atuação do poder público.

Assim, esse contexto explica a dificuldade inicial que o subsistema de saúde indígena enfrentou para executar as ações de saúde indígena nas aldeias, encontrando como alternativa administrativa a terceirização. No início da terceirização no Subsistema de saúde indígena se observou diversas formas da terceirização, onde a FUNASA assumia convênios com entidades indígenas e outras organizações não-governamentais de apoio à causa indígena (GARNELO, 2012).

Garnelo (2012) aponta ainda o modelo complexo de gestão da saúde indígena presente na época da FUNASA, onde coexistia diversos órgãos na saúde indígena, como o Ministério da Saúde, por meio da Secretaria de Atenção à Saúde (SAS), as prefeituras municipais, a execução direta do MS e as ONGs. A autora cita as disparidades de interesses, de prioridades, e de maneiras de funcionar das instituições envolvidas, tornando as relações institucionais difíceis e complexas. Acreditava-se que se tratava de um modelo de gestão transitório, que se alteraria com a instituição, no momento já prevista, da SESAI.

Atualmente nota-se que o modelo de gestão anteriormente apresentado não conseguiu ser superado, já que ainda hoje, com existência da SESAI na gestão da Política Nacional de Atenção à Saúde dos Povos Indígenas, a execução das ações de saúde fica à cargo de convênios com Organizações Não governamentais, o que 
inclui a contratação de força de trabalho para atuação na assistência à saúde indígena. No momento atual, são 3 (três) as instituições responsáveis pela contratação dessa FT: o Instituto de Medicina Integral Professor Fernando Figueira (IMIP), a Associação Paulista para o Desenvolvimento da Medicina (SPDM) e a Missão Evangélica Caiuá (BRASIL, 2014).

Essas instituições são entidades filantrópicas sem fins lucrativos, com percursos diferenciados na área da saúde indígena. O IMIP atua nas áreas de assistência médico-social, ensino, pesquisa e extensão comunitária, e possui convênio com o MS desde 2011 para desenvolver ações de saúde indígena nos estados de Pernambuco, Paraíba, Alagoas e Sergipe. A SPDM se dedica a contribuir para a melhoria dos serviços médicos prestados à população e possui parceria com o governo federal para atuar na assistência à saúde dos povos indígenas do Xingu desde 1999, permanecendo até os dias atuais (IMIP, 2016; SPDM, 2016).

A Missão Evangélica Caiuá, tem atuação junto à Funasa desde 1999, quando assumiu o DSEl de Mato Grosso do Sul, tendo as parcerias ampliadas e renovadas desde então. Atualmente é responsável por 18 (dezoito) DSEI, situados nos estados do Amazonas, Acre, Roraima, Santa Catarina, Paraná, Mato Grosso do Sul, Minas Gerais, Rondônia, Tocantins, e pela CASAI do DF (Missão Evangélica Caiuá, 2016).

Os dados referentes à força de trabalho ligada a estas 3 instituições foram disponibilizadas pelas mesmas, por intermédio da SESAI (coordenação de atenção primária à Saúde Indígena), como exposto na figura 11. 


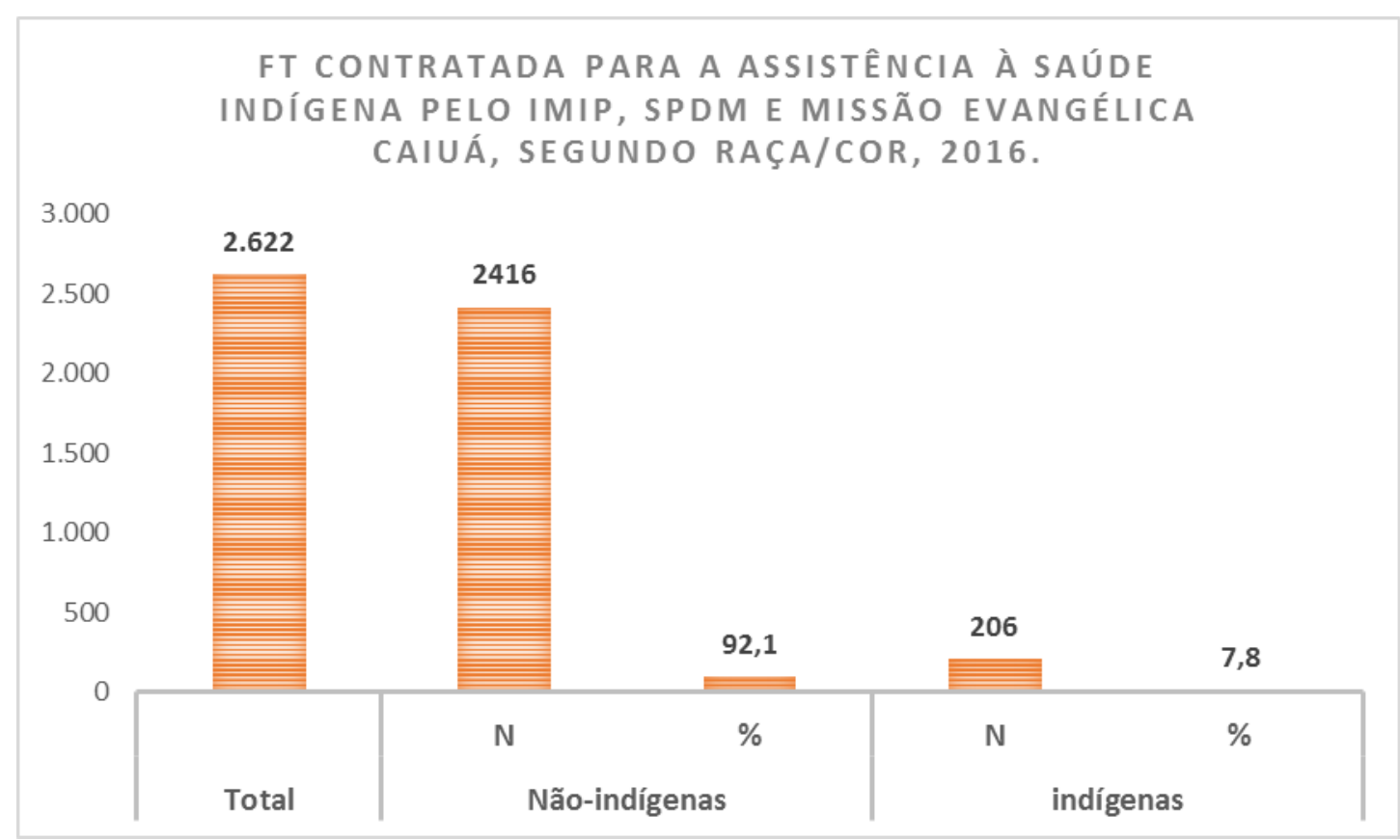

Figura 11 - Força de Trabalho contratada pelo IMIP, SPDM e Missão Evangélica Caiuá para a Assistência à Saúde Indígena, segundo raça/cor, 2016.

Fonte: IMIP, 2016; SPDM, 2016; Missão Evangélica Caiuá, 2016.

Nota-se que diferentemente da SESAI, as 3 (três) instituições responsáveis pela contratação de pessoal para a Saúde Indígena possuíam registro próprio da raça/cor de seus trabalhadores (as), o que permitiu a análise da distribuição racial da força de trabalho da saúde indígena. Vale destacar que alguns destes profissionais indígenas contratados pelas instituições filantrópicas não estão cadastrados no CNES, o que foi evidenciado pela informação dissonante entre os dois sistemas de registro, CNES aponta 138 profissionais indígenas na assistência e o IMIP, a SPDM e a Caiuá registram 206.

É importante trazer à luz que atualmente a FT de nível superior que atua na assistência à saúde indígena é majoritariamente formada por não-indígenas, tendo menos de $10 \%$ dos (as) trabalhadores (as) indígenas, considerando as 14 profissões de saúde objeto da pesquisa. Provavelmente, se fosse realizada uma análise da FT indígena total, considerando nível fundamental, técnico e superior, o panorama seria bem diferente, principalmente pela inserção dos AIS e dos AISAN, que obrigatoriamente precisam ser indígenas para se inserirem na função, e que diretamente acabam por elevar o percentual de indígenas inseridos no mercado de trabalho em saúde indígena. Mas, por que esse panorama se torna tão desfavorável para os indígenas quando envolve ocupações de nível superior?

A figura 12 mostra a distribuição destes 206 profissionais indígenas entre as 
entidades filantrópicas contratantes, gerando um retrato das instituições que mais contratam indígenas de nível superior, apesar da desproporção expressa nos dados anteriormente expostos.

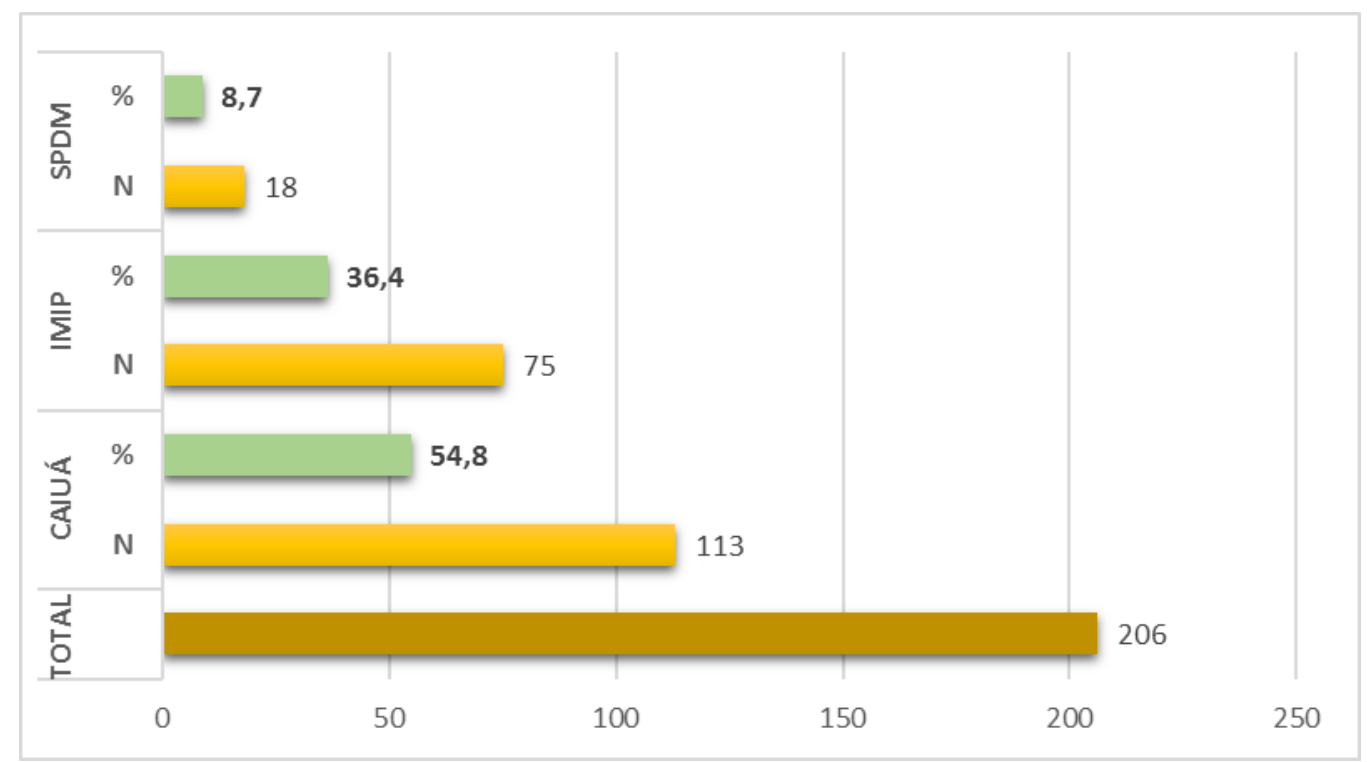

Figura 12 - Profissionais indígenas atuantes na Saúde Indígena por instituição contratante, no ano de 2016.

Fonte: IMIP, 2016; SPDM, 2016; Missão Evangélica Caiuá, 2016.

Nota-se, a partir de alguns editais de seleção simplificada de profissionais de saúde lançados no ano de 2016, que as três instituições contratantes adotam medidas diferenciadas para aumentar a inserção de indígenas na assistência à saúde específica nas aldeias. Vale destacar que apenas o IMIP lançou mão de pontuação específica ao candidato indígena ( 3 pontos), publicizada no edital $n^{-}$ 001/2016 destinado à formação de cadastro reserva de médicos para o DSEI AL/SE, além de utilizar a condição de "ser indígena" também como primeiro critério de desempate.

A SPDM no edital ํo 060/2016 destinado à contratação de Enfermeiro e Dentista para o DSEI Guamá-Tocantins, não disponibilizou pontuação específica na avaliação dos candidatos indígenas, utilizando a condição de "ser indígena" apenas como critério de desempate. Já a Missão Evangélica Caiuá, em seu edital oo 01/2016 para formação de cadastro reserva de Enfermeiro e Dentista não diferenciou candidatos indígenas dos não-indígenas. Vale ressaltar que em 2015 a Caiuá no edital № 01/2015 para seleção de Nutricionista, Enfermeiro, Dentista, Assistente Social e outros profissionais para atuação no DSEI Alto Rio Purus, adotou como critério de prioridade a condição de ser indígena. Isso demonstra que apesar 
de ter iniciado o investimento voltado à inclusão de indígenas no mercado de trabalho na saúde, essa iniciativa ainda não é permanente.

De acordo com o IMIP, a SPDM e a Caiuá, a categoria profissional que mais incorporou indígenas para atuar junto à "saúde indígena" foi o Serviço Social com $11,36 \%$ de profissionais indígenas, seguido da Enfermagem com 9\% (figura 13).

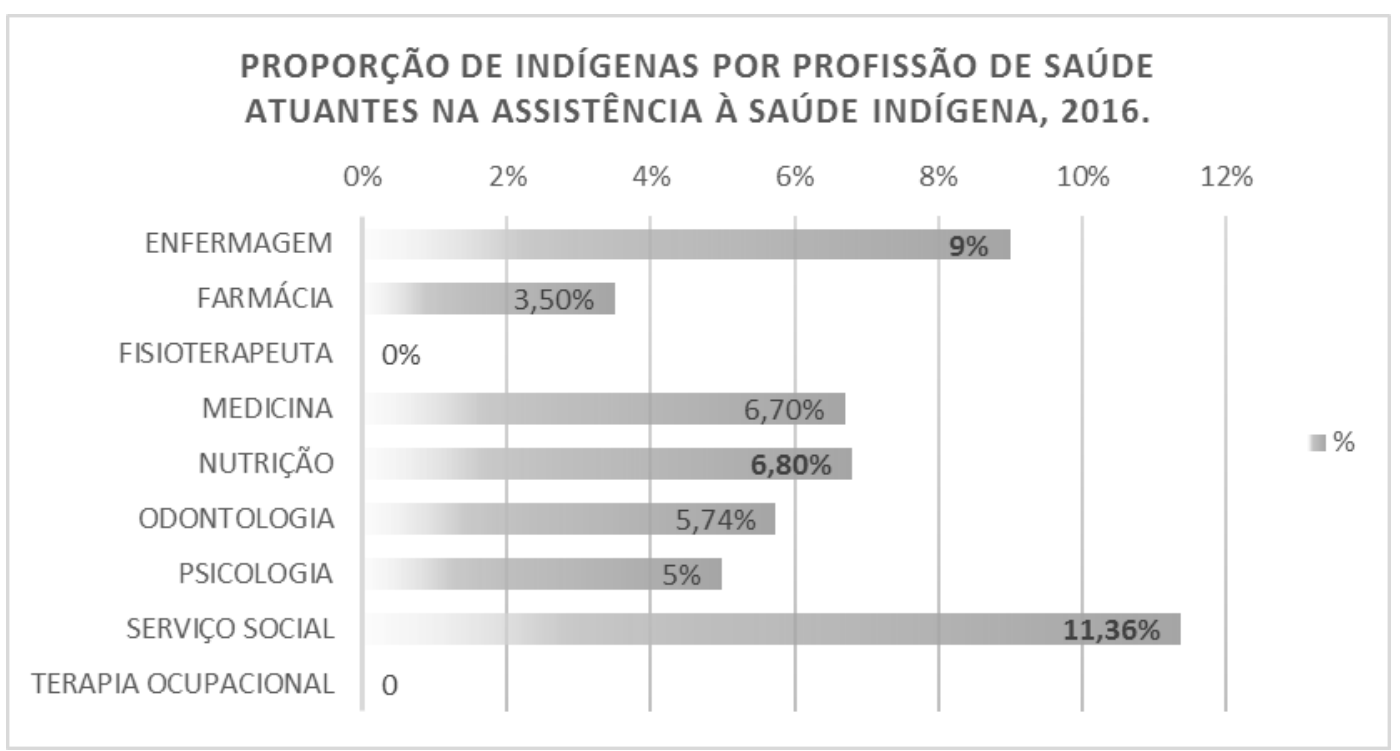

Figura 13 - Proporção de indígenas atuantes na assistência à "saúde indígena", desagregada por categoria profissional, em 2016.

Fonte: IMIP, 2016; SPDM, 2016; Missão Evangélica Caiuá, 2016.

Oliveira, Rosa e Pompeu (2015. p. 380) em seu trabalho sobre o Serviço social em contexto indígena expõem ligação direta entre a saúde indígena e o serviço social. Destacam que "a matéria-prima do trabalho do assistente social [...] encontra-se no âmbito da questão social em suas múltiplas manifestações [...]", e ainda que a globalização e a transculturalidade interferiram na vida dos povos indígenas, encenando uma realidade cultural que remete ao contexto histórico e que se torna complexa, exigindo a reinvenção e reorganização das práticas profissionais. Apontam um desafio para a atuação do Serviço Social que,

Se tratando de realidade indígena, consiste em exercitar permanentemente a arte de vivenciar, refletir, compreender e acompanhar a complexa teia de relações e vinculações do movimento histórico vivenciado pelas etnias, até onde os determinantes sociais, culturais e econômicos poderão afetar as estruturas e a qualidade de vida dos sujeitos envolvidos em sua ação (Oliveira, Rosa e Pompeu, 2015, p. 381). 
Assim, utilizando o próprio referencial dos autores supracitados, que consideram o Assistente Social como um pesquisador das relações sociais, preparado para realizar escuta holística, contínua e sistemática, pautada na realidade dos indivíduos e coletividades, infere-se que essa predominância de Assistentes Sociais na saúde indígena se dá por conta da complexidade social que envolve o ser indígena no Brasil, acompanhado de todo o cenário de violações e negação de direitos de cidadania que se apresenta nesse território, como apontado no capítulo 2.2.

\subsection{PRINCIPAIS NÓS CRÍTICOS DA FORÇA DE TRABALHO INDÍGENA EM} SAÚDE

Considerando o panorama da força de trabalho indígena apresentado nesse estudo, que comprova a presença de indígenas inseridos como profissionais de nível superior na assistência à saúde, evidencia-se diversos nós críticos ligados à formação profissional de indígenas e a sua inserção no mercado de trabalho em saúde, partindo do pressuposto que a formação e o mercado de trabalho são indissociáveis, sendo por este motivo apontados de maneira associada como desafios para a gestão do trabalho e mais amplamente para as políticas públicas no campo do trabalho em saúde.

Desta forma, é possível citar como principais nós críticos da força de trabalho indígena na saúde:

- Iniquidade racial na inserção profissional na assistência à saúde no Brasil, com alarmante desproporção de profissionais indígenas em comparação à brancos, negros e amarelos. O grupo étnico racial que menos está inserido no mercado de trabalho em saúde são os povos indígenas;

- Iniquidade racial na inserção de indígenas no ensino superior, nas grandes áreas de conhecimento, incluindo a saúde;

- Situação de não cidadania e/ou cidadania incompleta para diversas etnias indígenas como resultado da não garantia de direitos civis, políticos e sociais plenos, compromete negativamente $\mathrm{o}$ acesso de indígenas à formação e consequentemente à inserção no mercado de trabalho em saúde; 
- Baixa captação de indígenas para atuação na assistência à saúde específica dos povos indígenas pela SESAI, IMIP, SPDM e Missão evangélica Caiuá, considerando as 14 profissões de saúde incluídas na resolução № 287/1998 do Conselho Nacional de Saúde;

- Regras distintas utilizadas pelo IMIP, SPDM e Missão Evangélica Caiuá em editais de seleção de profissionais de saúde, visando a ampliação do acesso de profissionais indígenas ao mercado de trabalho da saúde indígena, e ausência de parâmetros ou recomendações oficiais por parte da SESAI para tal fim;

- Não evidenciação dos indígenas como profissionais de saúde de nível superior na Política Nacional de Atenção à Saúde dos Povos Indígenas, no que tange a formação de recursos humanos para atuar na Saúde Indígena;

- Inexistência de medidas afirmativas para ampliação do acesso de indígenas ao mercado de trabalho em saúde no Brasil;

- Possível descompasso entre a formação de força de trabalho indígena no ensino superior e a captação de profissionais indígenas no mercado de trabalho em saúde;

- Contradição entre as intenções e compromissos assumidos pelo Brasil para o enfrentamento das desigualdades raciais no mercado de trabalho e as ações legais para tal enfrentamento, que atualmente são excludentes dos povos indígenas, como por exemplo a Lei de cotas em concursos públicos de competência da União, que só considera sujeitos da ação de reparação os negros, desconsiderando e invisibilizando os indígenas, além de negar com isso, que as desigualdades raciais no mercado de trabalho atingem em grande medida os povos indígenas do Brasil;

- Ausência total dos (as) trabalhadores (as) indígenas das produções governamentais e acadêmicas referentes às desigualdades raciais no mercado de trabalho, restritas apenas à brancos e negros;

- Ausência quase total de produções científicas que abordem o (a) trabalhador (a) indígena de nível superior na saúde, considerando desde aspectos gerais de inserção no mercado de trabalho até questões qualitativas que buscam o conhecimento de especificidades destes (as) trabalhadores (as); 
- Contexto social de violência em unidades da federação que possuem profissionais de saúde indígenas atuando na assistência à saúde, apontando a complexidade que envolve a gestão da força de trabalho indígena no Brasil e evidenciando a necessidade de medidas de combate ao racismo e à violência contra estes (as) trabalhadores (as);

- Fragilidade do CNES no que tange o baixo preenchimento do quesito raça/cor, o que por um lado pode envolver os gestores e técnicos responsáveis pelo envio dos dados e por outro, os profissionais de saúde em seu processo de autodeclaração racial. 


\section{LIMITES DO ESTUDO}

Os principais limites do estudo são extremamente importantes, pois além de indicar entraves para a consecução dos objetivos traçados, também auxiliam no entendimento dos diversos fatores que interferem no levantamento da força de trabalho indígena na saúde. Considera-se as lacunas referentes aos povos indígenas nesse campo como dados e informações relevantes ao enfrentamento da invisibilidade e iniquidade que os envolvem no campo do trabalho em saúde. Sendo assim, os limites encontrados durante o estudo foram sistematizados em 4 (quatro) campos: Limites relacionados ao CNES, limites relacionados à Plataforma Força de Trabalho em Saúde, limites relacionados aos dados do MEC/INEP e limites relacionados à produção científica, como apresentados abaixo:

\subsection{LIMITES RELACIONADOS AO CNES:}

- Baixo preenchimento do item raça/cor na ficha de cadastro de profissionais de saúde no CNES;

- Alteração na ficha destinada ao cadastro de profissionais de saúde no CNES pelo Ministério da Saúde, de maneira interna e unilateral, ocasionando a retirada dos campos relacionados a gênero, raça e outros referentes aos profissionais de saúde vinculados aos estabelecimentos de saúde. Esta informação foi confirmada pela Coordenação Geral de Sistemas de Informação - (CGSI) da Secretaria de Atenção à Saúde (SAS/MS), no dia 17/10/2016 e posteriormente no dia 24/10/2016, após recurso em $1^{\underline{a}}$ instância devido ao envio incompleto das informações solicitadas por E-Sic, ancorado na Lei de acesso à informação. A data em que a alteração foi realizada não foi informada pelo MS, apesar de ter sido solicitada. A CGSI/SAS/MS informou que,

O CNES mantém apenas os campos de Cartão Nacional de Saúde (CNS), CPF e nome completo para identificação do profissional, visto que o sistema oficial para de identificar dados pessoais é o CNS. Todos os campos que 
foram retirados existem no CNS, bastando o cruzamento dos dados dos profissionais cadastrados no CNES com os dados desses indivíduos no CNS (CGSI/DRAC/SAS-MS, 2016).

E em resposta ao recurso apresentado pela pesquisadora acrescentaram ainda que,

O CNES não deixa de informar sobre profissionais, mas foca nos dados de vinculação. A identificação dos profissionais indígenas deverá ser feita com cruzamento entre a identificação do profissional do CNES (CNS) e dados complementares do CNS, que deve identificar a raça/cor, etnia (se for o caso) e gênero do cidadão (CGSI/DRAC/SAS-MS, 2016).

Desta forma, considerando as alterações internas realizadas pelo MS no CNES, que resultaram na exclusão dos campos de raça/cor, gênero e outros da ficha de cadastro dos profissionais de saúde, surgem algumas questões importantes ao debate que envolve os sistemas de informação utilizados para o levantamento da força de trabalho em saúde e o conhecimento da composição dessa força de trabalho: Sendo o quesito raça/cor e as questões de gênero de importância conhecida para a formulação de políticas públicas de enfrentamento às desigualdades raciais e de gênero no mercado de trabalho em saúde, qual o tamanho do impacto que tal exclusão pode trazer aos povos e segmentos alvos dos processos de iniquidade? Por qual motivo essa modificação não foi compartilhada com a sociedade em geral e com as universidades, como forma de construir um caminho que representasse avanço e não retrocesso? $\mathrm{E}$ ainda, quais as expertises que um cidadão (ã) comum terá que apresentar para extrair dados de dois bancos de dados distintos e cruzá-los, a fim de obter a caracterização racial da força de trabalho em saúde?

Todas essas questões apresentadas representam contradição clara do Ministério da Saúde com relação ao CNES ter como propósito legal o levantamento da força de trabalho em saúde, como exposto em portaria específica (BRASIL, 2015). Acredita-se que essa modificação no cadastro de profissionais que atuam na assistência irá dificultar o conhecimento racial da força de trabalho em saúde, o que irá interferir diretamente nas respostas do Estado à problemática que está posta nesse campo.

Portanto, considerando tais alterações como limites do estudo, para o alcance dos objetivos traçados, que exige a leitura racializada da Força de Trabalho em Saúde, foi utilizada a Plataforma Força de Trabalho em Saúde, 
que se utiliza, no momento, do cruzamento interno de dois bancos de dados para o levantamento dos referidos dados, o banco do CNES e do Cartão Nacional de Saúde, trabalho esse realizado pela Universidade Federal do Rio Grande do Norte (UFRN), parceira do MS na construção e qualificação da PFTS. A grande questão é que atualmente não existem documentos técnicos e/ou legais do Ministério da Saúde que informem sobre o funcionamento da PFTS, não existindo assim garantias que o cruzamento destes dois bancos de dados continuará existindo enquanto prática construtora da referida plataforma, para além das parcerias institucionais com universidades.

- Exclusividade do CNES como único sistema que permitia, até o ano de 2015, o levantamento da força de trabalho da assistência à saúde desagregado por raça/cor, com a consideração da categoria indígena.

\subsection{LIMITES RELACIONADOS A PLATAFORMA FORÇA DE TRABALHO EM SAÚDE:}

- Disponibiliza apenas dados do ano em que a pesquisa é feita, não fornecendo dados de anos anteriores, o que impossibilita a criação de série histórica para análise comparativa da força de trabalho em saúde;

- Não disponibiliza a opção de download dos dados fruto do cruzamento dos bancos de dados (CNES E CNS), por período;

- Apresenta inconsistência relacionada à identificação dos profissionais de saúde de uma região geográfica nos estados que o constituem;

- Ausência de documentos técnicos do Ministério da Saúde que expliquem em detalhes as funcionalidades, informações técnicas e limites da plataforma;

- Ausência de registros formais que sinalizem para a continuidade da leitura racial da força de trabalho em saúde, mesmo após a alteração sofrida pelo CNES.

\subsection{LIMITES RELACIONADOS AOS DADOS DO MEC/INEP:}


- Dados sobre os concluintes do ensino superior não desagregados por raça/cor nos censos do ensino superior do período de 2010 a 2015;

- Dados sobre os matriculados e concluintes específicos de cursos da saúde não desagregado por raça/cor nos censos do ensino superior de 2010 a 2015;

- Indisponibilidade dos dados referentes às IES que possuem vagas específicas para indígenas no Brasil, segundo resposta à solicitação realizada pela pesquisadora, via E-sic, ao MEC e ao INEP.

\subsection{LIMITES RELACIONADOS À PRODUÇÃO CIENTÍFICA:}

- Ausência quase total de produções científicas que abordem os profissionais indígenas de nível superior no mercado de trabalho em saúde (com exceção de uma pesquisa que incluiu indígenas na descrição da FT);

- Ausência total de produções científicas que abordem a gestão do trabalho de indígenas na saúde;

- Ausência total de produções científicas que incluam os indígenas nos referenciais sobre desigualdades raciais no mercado de trabalho, extrapolando a análise entre brancos e negros; 


\section{CONCLUSÕES E RECOMENDAÇÕES}

As informações que emergiram deste estudo são claras ao confirmar a presença de profissionais indígenas de saúde inseridos na assistência à saúde no Brasil, bem como a desproporção entre indígenas, brancos, negros e amarelos, sendo os indígenas o grupo que está menos inserido na assistência à saúde. Foi evidenciado também a invisibilidade dos indígenas nos referenciais teóricos, governamentais e acadêmicos, que tratam das desigualdades raciais no mercado de trabalho, o que traz um alerta importante para a necessidade de combater a invisibilidade dos indígenas nas produções e discussões que cercam o trabalho, o (a) trabalhador (a) e as desigualdades raciais no mercado de trabalho da saúde.

Realizar a leitura do contexto sócio histórico que envolve a vida dos povos indígenas no Brasil é indispensável para a análise coerente da força de trabalho indígena atuante na saúde, bem como para a compreensão dos processos que influenciaram tamanha desigualdade social entre as raças e etnias brasileiras. No Brasil, a raça é um eixo estruturante das relações sociais, dos conceitos, das leis e das políticas públicas, expresso claramente no racismo histórico do Estado contra os povos indígenas. Considerar tal contexto é dar um passo à frente rumo a promoção da igualdade racial e combate ao racismo no trabalho em saúde, considerando o indígena como protagonismo de sua história, de sua vida, e portanto, sujeito estratégico nesse processo.

Torna-se urgente a elaboração e execução de medidas de enfrentamento das desigualdades raciais no mercado de trabalho em saúde, tendo os indígenas como população-alvo e participantes ativos de tais ações; revisão da Lei de cotas em concursos públicos de competência da União, que, por questão de justiça e reparação social, deve incluir indígenas como público beneficiário; elaboração, pela SESAI/MS, de diretrizes nacionais que orientem à captação de profissionais indígenas de saúde, servindo de base para a contratação realizada pelo IMIP, SPDM e Missão evangélica Caiuá ou por outras instituições que por ventura estejam responsáveis pela contratação da FT na área, o que pode gerar futuramente a revisão da Política Nacional de Atenção à Saúde dos Povos Indígenas, auxiliando 
assim na priorização de indígenas como profissionais de saúde em terras indígenas e consequentemente na ampliação do quantitativo de profissionais indígenas nos serviços específicos cobertos pela PNASPI, corroborando assim com as reinvindicações dos povos indígenas durante a $5^{\underline{a}}$ Conferência Nacional de Saúde Indígena, como exposto no capítulo 2.4 .

É importante aprimorar os sistemas de informação em saúde existentes e/ou elaborar novos, afim de permitir a identificação de profissionais indígenas de saúde, por região geográfica e unidade da federação, buscando desenvolver mecanismos de gestão do trabalho desses profissionais, principalmente em regiões de conflito e violências envolvendo os povos indígenas como apontado nos capítulos 2.1 e 2.2 desta dissertação. Nesse campo destaca-se a fragilidade do CNES como sistema de informação destinado à identificar a força de trabalho em saúde, exigindo ações que envolvam gestores, técnicos vinculados à gestão, trabalhadores (as) da saúde e o Ministério da Saúde, a fim de contribuir para a conscientização desses atores sobre a importância dos dados raciais para a elaboração de políticas públicas de enfrentamento das desigualdades raciais no trabalho em saúde.

Acrescentando a este panorama de possibilidades, torna-se de extrema importância a Secretaria de Gestão do Trabalho e da Educação na Saúde (SGTES/MS) elaborar mecanismos e ações de estímulo à captação de profissionais indígenas de saúde nos programas de provisão e de qualificação da força de trabalho sob sua responsabilidade, como é o caso do Projeto Mais Médicos para o Brasil, do Programa de Valorização do Profissional da Atenção Básica (PROVAB) e do programa de Residências médicas e multiprofissionais em saúde, contribuindo para o aumento do número de médicos, enfermeiros e odontólogos indígenas inseridos na assistência à saúde, prioritariamente em terras indígenas, bem como para a qualificação dos diversos profissionais indígenas que atuam na área, a exemplo de nutricionistas, fisioterapeutas, psicólogos (as), assistentes sociais, farmacêuticos (as), dentre outros.

As medidas que visem ampliar o acesso e garantir a permanência de indígenas na formação no ensino superior em saúde são fundamentais para alargar o quantitativo de formação de força de trabalho indígena. Deve-se considerar a necessidade de encorajar as universidades a se adaptarem ao perfil dos graduandos indígenas, buscando com isso a efetivação do diálogo intercultural e o respeito à cultura indígena e aos modos tradicionais de cuidado que os estudantes indígenas 
trazem consigo na formação, que os acompanhará também em sua prática profissional na saúde. Destaca-se como estratégica a inserção de pajés e outros indígenas como tutores nos assuntos que se relacionam com o aprendizado em saúde, atuando de maneira complementar com os professores não-indígenas, a fim de acompanhar o percurso e orientar os estudantes indígenas inseridos nas universidades.

Portanto, conclui-se que o trabalho como direito social e consequentemente como direito de cidadania ainda encontra entraves para se tornar realidade para muitos dos profissionais indígenas da saúde. Toda essa distância existente entre os indígenas e seu acesso à formação e ao mercado de trabalho em saúde, é reflexo da não garantia da cidadania plena para os povos indígenas do Brasil, apontando para a necessidade de políticas, ações, programas e projetos que visem garantir a igualdade de oportunidades, o combate ao racismo e a garantia do trabalho como direito social de todos (as) os (as) indígenas que desejem se inserir no mercado de trabalho em saúde. 


\section{REFERÊNCIAS}

1. ABRAMO, Laís. Desigualdades de gênero e raça no mercado de trabalho brasileiro. Cienc. Cult. [online]. 2006, vol.58, n.4, pp. 40-41. Disponível em:http://cienciaecultura.bvs.br/scielo.php?pid=S000967252006000400020\&script=sci arttext. Acesso em: 15.JAN. 2016.

2.

AMARAL, W.R; BAIBICH,

T.M. A presença dos estudantes indígenas nas universidades estaduais do Paraná: trajetórias e pertencimentos. Revista Brasileira de Estudos Pedagógicos. V. 93. N 235. p. 818-835. 2012. Disponível em: http://www.scielo.br/pdf/rbeped/v93n235/14.pdf. Acesso em: 10. OUT. 2016.

3. BRASIL. Ministério da Saúde. Secretaria-Executiva. Secretaria de Gestão do Trabalho e da Educação na Saúde. Glossário temático: gestão do trabalho e da educação na saúde. 2. ed., Brasília: Ministério da Saúde, 2013.

4. Fundação Nacional de Saúde. Política Nacional de Atenção à Saúde dos Povos Indígenas. 2ª Ed. Brasília: Ministério da Saúde. 2002.

5. . Fundação Nacional do Índio (FUNAI). Índios do Brasil: quem são. 2016. Disponível em: http://www.funai.gov.br/index.php/indios-no-brasil/quem-sao. Acesso em: 26. SET. 2016.

6. Ministério da Saúde. Secretaria de Atenção à Saúde. Departamento de Atenção Básica. Política Nacional de Atenção Básica. Secretaria de Atenção à Saúde. Brasília: Ministério da Saúde, 2012. Disponível em: http://189.28.128.100/dab/docs/publicacoes/geral/pnab.pdf. Acesso em: 10. NOV. 2016.

7. Ministério da Saúde. Secretaria de Atenção à Saúde. Departamento de Regulação, Avaliação e Controle. Manual do Cadastro Nacional dos Estabelecimentos de Saúde - CNES. Versão 2. Brasília: Ministério da Saúde. 2006.

8. . Ministério da Educação. Inep. Sinopse do Censo do Ensino Superior 2015. Disponível em: http://portal.inep.gov.br/superior-censosuperior-sinopse. Acesso em:10. NOV. 2016.

9. Instituto de Pesquisa Econômica Aplicada (IPEA). Ministério do Planejamento, Desenvolvimento e Gestão. IPEA: quem somos. 2016. Disponível em: http://www.ipea.gov.br/portal/index.php?option=com content\&view=article\&id=1226\& Itemid=68. Acesso em: 30. DEZ. 2016. 
10. Instituto de Pesquisa Econômica Aplicada (IPEA). Fundo de Desenvolvimento das Nações Unidas para Mulher. Retrato das desigualdades de gênero e raça. $1^{\underline{a}}$ ed. - Brasília: Ipea, 2004. Disponível em: http://www.ipea.gov.br/retrato/pdf/revista.pdf. Acesso em: 10. JAN. 2016.

11. Instituto de Pesquisa Econômica Aplicada (IPEA). Fundo de Desenvolvimento das Nações Unidas para Mulher. Retrato das desigualdades de gênero e raça. $2^{a}$ ed. - Brasília: Ipea, 2006. Disponível em: http://www.ipea.gov.br/retrato/pdf/revista.pdf. Acesso em: 10. JAN. 2016.

12. Instituto de Pesquisa Econômica Aplicada (IPEA). Fundo de Desenvolvimento das Nações Unidas para Mulher. Retrato das desigualdades de gênero e raça. $3^{\text {a }}$ ed. - Brasília: Ipea, 2008. Disponível em: http://www.ipea.gov.br/retrato/pdf/revista.pdf. Acesso em: 10. JAN. 2016.

13. I I Instituto de Pesquisa Econômica Aplicada (IPEA). Fundo de Desenvolvimento das Nações Unidas para Mulher. Retrato das desigualdades de gênero e raça. 4ํㅡㄹ - Brasília: Ipea, 2011. Disponível em: http://www.ipea.gov.br/retrato/pdf/revista.pdf. Acesso em: 10. JAN. 2016.

14. . Lei no 12.711, de

29 de agosto de 2012, que dispõe sobre o ingresso nas universidades federais e nas instituições federais de ensino técnico de nível médio e dá outras providências. Disponível em: $\quad$ http://www.planalto.gov.br/ccivil 03/ ato20112014/2012/Lei/L12711.htm. Acesso em: 10.OUT. 2016.

15. . Decreto no 7.824, de 11 de outubro de 2012, que regulamenta a Lei no 12.711 , de 29 de agosto de 2012, que dispõe sobre o ingresso nas universidades federais e nas instituições federais de ensino técnico de nível médio. Disponível em: http://www.planalto.gov.br/CCIVIL 03/ Ato2011-2014/2012/Decreto/D7824.htm.

Acesso em: 10. OUT. 2016.

16. Lei 12.990, de 9 de junho de 2014, que dispõe sobre a reserva aos negros $20 \%$ (vinte por cento) das vagas oferecidas nos concursos públicos para provimento de cargos efetivos e empregos públicos no âmbito da administração pública federal, das autarquias, das fundações públicas, das empresas públicas e das sociedades de economia mista controladas pela União. Disponível em: http://www.planalto.gov.br/ccivil 03/ Ato2011-2014/2014/Lei/L12990.htm. Acesso em: 10. NOV. 2016.

17. Ministério do Trabalho e Emprego. Agenda Nacional do Trabalho Decente (ANTD). Brasília: MTE. 2006. Disponível em: http://acesso.mte.gov.br/data/files/FF8080812BCB2790012BD50168314818/pub Ag enda Nacional Trabalho.pdf. Acesso em: 10. NOV. 2016. 
18. Ministério da Saúde.

Protocolo 009/2015, que Institui as diretrizes da Agenda Nacional do Trabalho Decente para Trabalhadores e Trabalhadoras do Sistema Único de Saúde (ANTDSUS). 2015.2 Disponível em: http://u.saude.gov.br/images/pdf/2015/dezembro/02/protocolo-mesa009.pdf. Acesso em: 10.0UT. 2016.

19.

Portaria 1.646, de 2 de outubro de 2015. Institui o Cadastro Nacional de Estabelecimentos de Saúde (CNES). Disponível em: http://bvsms.saude.gov.br/bvs/saudelegis/gm/2015/prt1646_02_10_2015.html. Acesso em: 20. OUT. 2016.

20. Resolução no 287/98 do Conselho Nacional de Saúde (CNS). Relaciona as 14 (quatorze) profissões de saúde de nível superior para fins de atuação do Conselho. 1998. Disponível em: http://conselho.saude.gov.br/resolucoes/reso_98.htm. Acesso em: 14. JUL. 2016. 21. . Ministério da Saúde. Plataforma Força de Trabalho em Saúde (PFTS). 2016. Disponível em: http://rhsus.ufrn.br/site/. Acesso em: 15. FEV. 2016. 22. Ministério da Saúde. Secretaria de Gestão do Trabalho e da Educação na Saúde (SGTES). Plataforma reunirá dados sobre a Força de Trabalho em Saúde do país. 2015. Disponível em: http://portalsaude.saude.gov.br/index.php/oministerio/principal/secretarias/sgtes/sgtes-gestao-do-trabalho/noticias-gestao-dotrabalho/20255-plataforma-reunira-dados-sobre-profissionais-de-saude-do-pais-2. Acesso em: 25. JAN. 2016.

23. Secretaria Especial de Saúde Indígena. Chamamento público. 2014. Disponível em: http://portalsaude.saude.gov.br/index.php/oministerio/principal/secretarias/secretaria-sesai/mais-sobre-sesai/9519-destaques. Acesso em: 10. JAN. 2016.

24. . Secretaria Especial de Saúde Indígena. Balanço SESAl. 2015.2 Disponível em: http://www2.camara.leg.br\%2Fatividade-legislativa\%2. Acesso em: 10. JAN. 2016. 25. Ministério da Saúde. 5a

Conferência Nacional de Saúde Indígena: relatório final / Ministério da Saúde, Conselho Nacional de Saúde. - Brasília: Ministério da Saúde, 2015. Disponível em: http://conselho.saude.gov.br/biblioteca/Relatorios/02fev 01 relatorio final 5cnsi.pdf. Acesso em: 15. JAN. 2016. 
26.

BASTA, P.C; ORELLANA, J. D.Y;

ARANTES, R. Perfil epidemiológico dos povos indígenas no Brasil: notas sobre agravos selecionados. Cap. 2. In GARNELO, L; PONTES, A.L. Saúde Indígena: uma introdução ao tema. Brasília: MEC-SECADI, 2012. Disponível em: http://bvsms.saude.gov.br/bvs/publicacoes/saude indigena uma introducao tema.p df. Acesso em: 15. JAN. 2016.

27. BERNARDES, A.G. Saúde indígena e políticas públicas: alteridade e estado de exceção. Revista Interface, comunicação, saúde, educação. v.15, n.36, p.153-64. 2011. Disponível em: http://www.scielo.br/scielo.php?script=sci arttext\&pid=S141432832011000100012. Acesso em: 23. OUT. 2016.

28. CAPIBERIBE, A; BONILLA, O. A ocupação do congresso: contra o quê lutam os índios? Revista estudos avançados. Edição. 29. p. 293-313. 2015. Disponível em: http://www.scielo.br/scielo.php?script=sci arttext\&pid=S0103-40142015000100293. Acesso em: 13. SET. 2016.

29. CARVALHO, J.M. Cidadania no Brasil: o longo caminho. Rio de Janeiro: Civilização Brasileira, 3를. 2002.

30. CARVALHO, M; SANTOS, N. R. dos; CAMPOS, G. W. S. A construção do SUS e o planejamento da força de trabalho em saúde no Brasil: breve trajetória histórica. Revista Saúde em debate [online]. vol.37, n.98, 2013. Disponível em: http://www.scielo.br/scielo.php?script=sci arttext\&pid=S010311042013000300002\&lng=en\&nrm=iso\&tlng=pt. Acesso em: 10. AGO. 2016.

31. CHADAREVIAN, P. C. Para medir as desigualdades raciais no mercado de trabalho. Revista de Economia Política. [online]. v. 31, n.2, 2011. Disponível em: http://www.scielo.br/scielo.php?script=sci arttext\&pid=S0101-31572011000200007. Acesso em: 13. SET. 2016.

32. CHIRIBOGA, O.R. O direito à identidade cultural dos povos indígenas e das minorias nacionais: um olhar a partir do sistema interamericano. Revista Internacional de Direitos Humanos. N. 5 - ANO 3 - 2006. Disponível em: www.surjournal.org. Acesso em: 01. OUT. 2016. Disponível em: http://www.scielo.br/pdf/sur/v3n5/v3n5a03.pdf. Acesso em: 10. SET. 2016.

33. CIMI. Relatório da Violência contra os povos indígenas. 2012. Disponível em: http://www.cimi.org.br/pub/viol/viol2012.pdf. Acesso em: 10.JAN. 2016.

34. CIMI. Relatório da Violência contra os povos indígenas. 2015. Disponível em: http://www.cimi.org.br/site/pt-br/?system=publicacoes\&cid=30. Acesso em: 10.Nov. 2016.

35. COIMBRA JR., C.E. A. Saúde e povos indígenas no Brasil: reflexões a partir do I Inquérito Nacional de Saúde e Nutrição Indígena. Cad. Saúde Pública [online]. 2014, 
vol.30,

n.4,

pp.855-859.

Disponível

em:

http://www.scielo.br/scielo.php?script=sci arttext\&pid=S0102-311X2014000400855.

Acesso em: 24. DEZ. 2016.

36. CORDEIRO, H.A. O conceito de necessidades de saúde e as políticas sanitárias In AMÂNCIO FILHO, A; MOREIRA, M.C.G.B. Saúde, trabalho e formação profissional. Rio de Janeiro: FIOCRUZ, 1997.

37. CUNHA, M.C. Índios no Brasil: história, direitos e cidadania. $1^{\underline{a}}$ ed. São Paulo: Claro Enigma, $2012 . \quad$ Disponível em: http://www.companhiadasletras.com.br/trechos/35025.pdf. Acesso em: 10. JUN. 2016.

38. DAL POZ, M. R. A crise da força de trabalho em saúde. Cadernos de saúde pública. $\quad$ v. $29 . \quad$ n. 10.2013 .2 Disponível em: http://www.scielo.br/scielo.php?script=sci arttext\&pid=S0102-311X2013001000002. Acesso em: 14. MAR. 2016.

39. DAL POZ, M.R; PERANTONI, CR; GIRARDI, S. Formação, mercado de trabalho e regulação da força de trabalho em saúde no Brasil. In FUNDAÇÃO OSWALDO CRUZ. A saúde no Brasil em 2030 - prospecção estratégica do sistema de saúde brasileiro: organização e gestão do sistema de saúde [online]. Rio de Janeiro: Fiocruz/Ipea/Ministério da Saúde/Secretaria de assuntos Estratégicos da Presidência da República, 2013. V. $3 . \quad$ Disponível em: http://books.scielo.org/id/98kjw/pdf/noronha-9788581100173-07.pdf. Acesso em: 03. JAN. 2016.

40. DAVID, M; MELO, M.L; MALHEIRO, J.M.S. Desafios do currículo multicultural na educação superior para indígenas. Revista Educação e Pesquisa. São Paulo. v. 39.
$\mathrm{n}$.
1.
2013.
Disponível
em:

http://www.scielo.br/scielo.php?script=sci arttext\&pid=S1517-97022013000100008. Acesso em: 5. FEV. 2016.

41. DIEHL, E. E; LANGDON, E. J; DIAS-SCOPEL, R. P. Contribuição dos agentes indígenas de saúde na atenção diferenciada à saúde dos povos indígenas brasileiros. Cadernos de Saúde Pública [online]. vol.28, n.5, 2012. Disponível em: http://www.scielo.br/scielo.php?script=sci arttext\&pid=S0102-311X2012000500002. Acesso em: 12. AGO. 2016.

42. DIEHL, E. E; PELLEGRINI, M.A. Saúde e povos indígenas no Brasil: o desafio da formação e educação permanente de trabalhadores para atuação em contextos interculturais. Cadernos de saúde pública. Rio de Janeiro. v. 30. n. 4. 2014. Disponível em: http://www.scielo.br/pdf/csp/v30n4/0102-311X-csp-30-4-0867.pdf. Acesso em: 10. NOV. 2016. 
43. DUARTE, Newton. Limites e contradições da cidadania na sociedade capitalista. Revista Pro-Posições [online]. 2010, vol.21, n.1. Disponível em: http://www.scielo.br/scielo.php?script=sci arttext\&pid=S010373072010000100006\&lng=en\&nrm=iso\&tlng=pt. Acesso em: 10. AGO. 2016.

44. FERREIRA, MEV et al. Aspectos Demográficos e Mortalidade de Populações Indígenas. Caderno de Saúde Pública, Rio de Janeiro, 27(12):2327-2339, dez, 2011. 45. FERREIRA, M.E. V; MATSUO, T.; SOUZA, R. K. T. Aspectos demográficos e mortalidade de populações indígenas do Estado do Mato Grosso do Sul, Brasil. Cadernos de Saúde Pública [online]. vol.27, n.12, 2011. Disponível em: http://www.scielo.br/scielo.php?script=sci arttext\&pid=S0102-311X2011001200005. Acesso em: 10. MAR. 2016.

46. FERREIRA, L.B; PORTILLO, J.A.C; NASCIMENTO, W.F.N. A criação da Secretaria Especial de Saúde Indígena. Tempus Actas de Saúde Coletiva. 2013. Disponível em: http://www.tempusactas.unb.br/index.php/tempus/article/view/1419. Acesso em: 20. OUT. 2016.

47. FOUCAULT, Michel. Em defesa da sociedade: curso no Collège de France (1975 1976). São Paulo: Martins Fontes. 4aㅡ ed. 2005.

48. FRANCHETO, B. Assessor, pesquisador: reflexões em torno de uma experiência em "educação indígena". In: FERREIRA, Mariana K.L.; SILVA, A. L. Práticas pedagógicas na Escola Indígena. São Paulo: Global, 2001 apud SILVA, M.J.S; MARQUES, E.P.S. Os desafios e conquistas dos indígenas na educação superior em Mato Grosso do Sul (MS). Revista Pedagogia em foco. V. 11. N. 5. P. 109 - 119. 2016.

Disponível

em:

http://www.facfama.edu.br/revista/index.php/PedF/article/view/171.

49. GARLET, M; GUIMARÃES, G; BELLINI, M. I. B. Cotas para estudantes indígenas: inclusão universitária ou exclusão escolar? Revista de Educação. Porto alegre. v. 33. n. $2010 . \quad$ Disponível em: http://revistaseletronicas.pucrs.br/ojs/index.php/faced/article/view/5208. Acesso em: 5. FEV. 2016.

50.

GARNELO, L. Política de

Saúde Indígena no Brasil: notas sobre as tendências atuais do processo de implantação do subsistema de atenção à saúde in BRASIL. Ministério da Educação. Saúde Indígena: uma introdução ao tema. Brasília: MEC - SECADI, 2012.

51. GIL, A. C. Métodos e técnicas de pesquisa social. 6. ed. - São Paulo : Atlas, 2008. 52.

GUIMARÃES, A. S. A. A questão racial na política brasileira (os últimos quinze anos). Tempo soc. [online]. 2001. vol.13, n.2, pp.121-142. Disponível em: 
http://www.scielo.br/scielo.php?script=sci arttext\&pid=S010320702001000200007\&ln $\mathrm{g}=\mathrm{pt \& nrm=iso}$. Acesso em: 10. SET. 2016.

53.

HADDAD, A. E. et al.

Formação de profissionais de saúde no Brasil: uma análise no período de 1991 a 2008. Rev. Saúde Pública [online]. 2010, vol.44, n.3. Disponível em: http://www.scielo.br/scielo.php?script=sci arttext\&pid=S0034-89102010000300001. Acesso em: 13. SET. 2016.

54. HERINGER, Rosana. Desigualdades raciais no Brasil: síntese de indicadores e desafios no campo das políticas públicas. Cadernos de Saúde Pública [online]. 2002, vol.18. Disponível em: http://www.scielo.br/pdf/csp/v18s0/13793.pdf. Acesso em: 10.OUT. 2016.

55.

HIMMELWEIT, S. Valor da

força de trabalho. In BOTTOMORE, T. Dicionário do pensamento Marxista. Rio de janeiro: Jorge Zahar Editor, 2001. Apud VIEIRA, P.A. As especificidades da mercadoria força de trabalho: Marx revisitado. Acta scientiarum - human and social sciences. Maringá. V. 34. n. 2. 2012. Disponível em: http://periodicos.uem.br/ojs/index.php/ActaSciHumanSocSci/article/view/18632. Acesso em: 15. MAI. 2016.

56. IBGE. Instituto Brasileiro de Geografia e Estatística. Os Indígenas no Censo demográfico 2010: primeiras considerações com base no quesito raça cor. Brasília: IBGE, $2012 . \quad$ Disponível em: http://www.ibge.gov.br/indigenas/indigena_censo2010.pdf. Acesso em: 23.SET. 2016.

57.___. Relação Anual de Informações Sociais (RAIS). 2016. Disponível em: http://ces.ibge.gov.br/base-de-dados/metadados/mte/relacao-anual-de-informacoessociais-rais.html. Acesso em: 06. NOV. 2016.

58.

IMIP. Saúde Indígena. 2016.

Disponível em: http://www1.imip.org.br/imip/assistenciaesaude/saudeindigena/apresentacao.html. Acesso em: 10. NOV. 2016.

59. KOSTER, I; MACHADO, M.H. A gestão do trabalho e o contexto da flexibilidade no Sistema Único de Saúde. Revista Divulgação em saúde para debate. Rio de Janeiro: CEBES. n. 47. 2012. 
60. LAVALLE, A.G. Cidadania, igualdade e diferença. Revista de cultura e política Lua nova, São Paulo, $\mathrm{n}$ 59. 2003. Disponível em: http://www.scielo.br/pdf/In/n59/a04n59.pdf. Acesso em: 02. OUT. 2016.

61.

LHUILIER, D. Trabalho.

Revista Psicologia e sociedade. v. 25. n. 3. 2013. Disponível em: http://www.ufrgs.br/seerpsicsoc/ojs2/index.php/seerpsicsoc/article/view/3642. Acesso em: 16. SET. 2016.

62. LIMA, A.C.S. Educação Superior para Indígenas no Brasil: sobre cotas e algo mais. Seminário Formação Jurídica e povos indígenas: desafios para uma educação superior. Pará: LACED - Laboratório de Pesquisa em etnicidade, cultura e desenvolvimento. $2007 . \quad$ Disponível em: http://www.ufpa.br/juridico/documentos/textoAntonio.pdf. Acesso em: 23. MAI. 2015.

63. LIMA, A.C.S. A Educação Superior de Indígenas no Brasil contemporâneo: reflexões sobre as ações do Projeto Trilhas de Conhecimentos. Revista História hoje. v. 1. n. 2. 2012. Disponível em: https://rhhi.anpuh.org/RHHJ/article/view/46. Acesso em: 22. MAR. 2016.

64. LUCIANO, G. S. O índio brasileiro: o que você precisa saber sobre os povos indígenas no Brasil de hoje. Brasília, DF: Ministério da Educação. 2006. Disponível em: http://unesdoc.unesco.org/images/0015/001545/154565por.pdf. Acesso em: 03. OUT. 2016.

65. LUCIANO, G. S. O papel da universidade sob a ótica dos povos e acadêmicos indígenas In NASCIMENTO, A.C et al. Povos indígenas e sustentabilidade: saberes e práticas interculturais nas universidades. Campo Grande: UCDB, 2009. Disponível em: http://flacso.redelivre.org.br/files/2012/07/361.pdf. Acesso em: 15. NOV. 2016.

66. MACHADO et al. Características gerais da enfermagem: o perfil sociodemográfico. Revista Enfermagem em foco. v. 7. pg. 63-76. 2016.

67. MACHADO et al. Condições de trabalho da enfermagem. Revista Enfermagem em foco. v. 7. pg. 63-76. 2016. 68. MACHADO, M. H; OLIVEIRA, E. S. Mercado de trabalho: Em que trabalham e quem emprega estes trabalhadores? Cap. 3. Trabalhadores de saúde em números. v. 2. Rio de Janeiro: Escola Nacional de Saúde Pública Sérgio Arouca. 2006.

69. MARX, Karl. Salário, preço e lucro. $1^{\text {a }}$ ed. Lisboa: Avante. 1984.

70. MENÉNDEZ, E. Modelos de atención de los padecimientos: de exclusiones teóricas y articulaciones prácticas. Revista Ciência \& Saúde Coletiva. v. 8, n.1, 2003. 
Disponível em: http://www.scielo.br/pdf/csc/v8n1/a14v08n1.pdf. Acesso em: 12. AGO. 2016.

71. MINAYO, Maria Cecilia de S; SANCHES, ODÉCIO. Quantitativo-Qualitativo: Oposição ou Complementaridade? Caderno de Saúde Pública, Rio de Janeiro, p. 239-262, $1993 . \quad$ Disponível em: http://www.scielo.br/scielo.php?script=sci arttext\&pid=S0102-311X1993000300002. Acesso em: 15. OUT. 2016.

72. MISSÃO EVANGÉLICA CAIUÁ. 2016. Disponível em: http://www.missaocaiua.org.br. Acesso em: 10. NOV. 2016.

73. MOORE, C. O marxismo e a questão racial: Karl Marx e Friedrich Engels frente ao racismo e à escravidão. Belo Horizonte: Nandyala; Uberlândia: Cenafro. Coleção repensando África, v. 5. 2010.

74.

MOTA, C. N. Ser indígena no

Brasil contemporâneo: novos rumos para um velho dilema. Cienc. Cult. [online]. 2008, vol.60, $\quad$ n.4. Disponível em: http://cienciaecultura.bvs.br/pdf/cic/v60n4/a11v60n4.pdf. Acesso em: 20. DEZ. 2016.

75. NOGUEIRA, Roberto Passos. A força de trabalho em saúde. Revista de Administração Pública [online]. 1983, vol.17, n.3, pp. 61-70. Disponível em:http://bibliotecadigital.fgv.br/ojs/index.php/rap/article/viewFile/10660/9657. Acesso em: 20. MAI. 2016.

76. NOGUEIRA, Roberto Passos. A força de trabalho em saúde no contexto da Reforma Sanitária. Cadernos de Saúde Pública. v. 3. n. 3. 1987. Disponível em: http://www.scielo.br/scielo.php?script=sci arttext\&pid=S0102-311X1987000300011. Acesso em: 10. MAR. 2016.

77. OLIVEIRA, R.N.C; ROSA, L.C.S; POMPEU, J.R.A. Serviço Social no contexto indígena: as transformações societárias e os desafios da profissão. Revista o social em questão. Ano XVIII - no 33 - 2015. Disponível em: http://osocialemquestao.ser.pucrio.br/media/OSQ 33 SL3 Oliveira Rosa Pompeu.pdf. Acesso em: 08. NOV. 2016. 78. OIT. Organização Internacional do Trabalho. Convenção 111, de 25 de junho de 1958. Disponível em: http://www.oit.org.br/node/472. Acesso em: 10. NOV. 2016.

79.___ Convenção 169, de 7 de junho de 1989. Disponível em: http://www.oitbrasil.org.br/node/513. Acesso em: 31. DEZ. 2016.

80. Convenções ratificadas pelo Brasil. 2016. Disponível em: http://www.oitbrasil.org.br/convention. Acesso em: 31.DEZ. 2016. 
81. PACHECO, R. A. S; PRADO, R. C. O. do; KADWÉU, E. V. População carcerária indígena e o direito à diferença: o caso do município de Dourados, MS. Revista Direito GV. São Paulo. 7(2). p. 469-500. JUL-DEZ, 2011. Disponível em: http://www.scielo.br/scielo.php?script=sci arttext\&pid=S1808-24322011000200005. Acesso em: 01. OUT. 2016.

82. PAIM, J.S. Recursos Humanos em Saúde no Brasil: problemas crônicos e desafios agudos. São Paulo: Faculdade de Saúde Pública/USP, 1994.

83. PAGLIARO, H; AZEVEDO, M.M; SANTOS, R.V. Demografia dos povos indígenas no Brasil: um panorama crítico. Cap. 1. in Demografia dos povos indígenas no Brasil [online]. Rio de Janeiro: Editora FIOCRUZ, 2005. Disponível em: http://static.scielo.org/scielobooks/qdgat/pdf/pagliaro-788575412541.pdf. Acesso em: 14. JAN. 2016.

84. PEREIRA, L. D. A gestão da força de trabalho em saúde na década de 90 . Physis - Revista de Saúde Coletiva. v.14, n. 2, 2004. Disponível em: http://www.scielo.br/scielo.php?script=sci arttext\&pid=S0103-

$\underline{73312004000200010 \& \operatorname{lng}=p t \& n r m=i s o}$. Acesso em: 10. MAR. 2016.

85. PIGNATI, W. Os riscos, agravos e vigilância em saúde no espaço do desenvolvimento do agronegócio no Mato Grosso. 2007. Tese (Doutorado) Fundação Osvaldo Cruz/ENSP. Rio de Janeiro, 2007. Disponível em: http://www.scielo.br/scielo.php?script=sci nlinks\&ref=000156\&pid=S0104$1290200900040001000028 \&$ Ing=pt. Acesso em: 10. OUT. 2016.

86.

POLANYI, K. A grande

transformação: as origens de nossa época. Rio de Janeiro: Campus. 2000. Apud VIEIRA, P.A. As especificidades da mercadoria força de trabalho: Marx revisitado. Acta scientiarum - human and social sciences. Maringá. V. 34. n. 2. 2012. Disponível em: http://periodicos.uem.br/ojs/index.php/ActaSciHumanSocSci/article/view/18632. Acesso em: 15. MAI. 2016.

87.

PONTES, A.L; STAUFFER, A;

GARNELO, L. Profissionalização indígena no campo da saúde: desafios para a formação técnica de Agentes Indígenas de Saúde in BRASIL. Ministério da Educação. Saúde Indígena: uma introdução ao tema. Brasília: MEC - SECADI, 2012.

88. PRADO JR., C. Evolução política do Brasil: Colônia e império, 21. ed., São Paulo: Brasiliense. 1994.

89. RIBEIRO, A. A. et al. O trabalho de enfermagem em uma instituição de apoio ao indígena. Revista texto e contexto. Florianópolis. v. 24. n. 1. 2015. Disponível em: 
http://www.scielo.br/pdf/tce/v24n1/pt 0104-0707-tce-24-01-00138.pdf. Acesso em: 10. AGO. 2016.

90. RIBEIRO, C.D. Justiça social e equidade em saúde: uma abordagem centrada nos funcionamentos. Revista Saúde e Sociedade. São Paulo, v.24, n.4, p.1109-1118, 2015. Disponível em: http://www.scielo.br/pdf/sausoc/v24n4/1984-0470-sausoc-2404-01109.pdf. Acesso em: 02. OUT. 2016.

91.

ROCHA, E.S.C. Uma etnografia das práticas sanitárias no distrito sanitário especial indígena do Rio Negro noroeste do Amazonas [dissertação de mestrado]. Manaus: UFAM, 2007. Disponível em: http://tede.ufam.edu.br/handle/tede/2280?locale=pt BR. Acesso em: 03. NOV. 2016.

92.

RODRIGUES, I.C; NOVAK, M.S.J; FAUSTINO, R.C. A política pública de educação superior indígena no Paraná: percursos, dilemas e perspectivas. Revista muitas vozes. Ponta grossa. V. 3. N. $1.2014 . \quad$ Disponível em: http://www.revistas2.uepg.br/index.php/muitasvozes/article/view/7253/pdf 172. Acesso em: 10. NOV. 2016.

93. SALES JÚNIOR, R. Democracia racial: o não dito racista. Revista Tempo social. USP, v.18, n.2, p.229-58, 2006.

94.

SANTOS, A.B.S; COELHO,

T.C.B; ARAÚJO, E.M. Identificação racial e a produção da informação em saúde. Revista interface comunicação, saúde e educação. V. 17. N. 45. P. 341-345. 2013. Disponível em: http://www.scielo.br/pdf/icse/2013nahead/aop0313.pdf. Acesso em: 10. NOV. 2016.

95.

SCOPEL, D; DIAS-SCOPEL,

R. P; LANGDON, E J. Intermedicalidade e protagonismo: a atuação dos agentes indígenas de saúde Munduruku da Terra Indígena Kwatá-Laranjal, Amazonas, Brasil. Cadernos de Saúde Pública [online]. vol.31, n.12, 2015. Disponível em: http://www.scielo.br/scielo.php?script=sci arttext\&pid=S0102-

311X2015001202559\&lng=en\&nrm=iso\&tlng=pt. Acesso em: 12. AGO. 2016.

96. SEN, A. Desigualdade reexaminada. Rio de Janeiro: Record, 2001.

97. SILVA, G. M. D. Ações afirmativas no Brasil e na África do Sul. Revista Tempo social. $\quad$ v. $18 . \quad$ n. 2 2 2006 . Disponível em: http://www.revistas.usp.br/ts/article/view/12518. Acesso em: 10. AGO. 2016. 98.

SILVA, M.J.S; MARQUES, E.P.S. Os desafios e conquistas dos indígenas na educação superior em Mato Grosso do Sul (MS). Revista Pedagogia em foco. v. 11. n. 5. p. 109 - 119. 2016. 
Disponível em: http://www.facfama.edu.br/revista/index.php/PedF/article/view/171. Acesso em: 10. OUT. 2016.

99. SIMONI, A.T; DAGNINO, R.S.

Dinâmica demográfica da população indígena em áreas urbanas: o caso da cidade de Altamira, Pará. Revista brasileira de estudos de população [online]. vol.33, n.2, $2016 . \quad$ Disponível em: http://www.scielo.br/scielo.php?script=sci arttext\&pid=S010230982016000200303\&lng=pt\&nrm=iso\&tlng=pt. Acesso em: 14. JAN. 2016.

100. SOUZA, J. (Não) reconhecimento e subcidadania ou o que é "ser gente"? Revista de cultura política - Lua nova. n. 59, 2003. Disponível em: http://www.scielo.br/scielo.php?script=sci arttext\&pid=S0102-64452003000200003. Acesso em: 02. OUT. 2016.

101. SPDM. Projeto Xingu. 2016. Disponível em: https://www.spdm.org.br/projetossociais/projeto-xingu. Acesso em: 09. NOV. 2016.

102. TAVOLARO, S. B. F; TAVOLARO, Lília G. M. A cidadania sob o signo do desvio: Para uma crítica da "tese de excepcionalidade brasileira". Revista sociedade e Estado. [online]. 2010, vol.25, n.2. Disponível em: http://www.scielo.br/scielo.php?script=sci arttext\&pid=S0102-69922010000200009. Acesso em: 10. SET. 2016.

103. TOMEI, M. Organização Internacional do Trabalho. Ação afirmativa para a igualdade racial: características, impactos e desafios. Brasília: OIT. 2005. Disponível em: http://www.oit.org.br/content/a\%C3\%A7\%C3\%A3o-afirmativa-paraigualdade-racial-caracter\%C3\%ADsticas-impactos-e-desafios. Acesso em: 14. FEV. 2016.

104. TORRES, C. M. R et al. A contra-reforma da educação superior: uma análise do ANDES-SN das principais iniciativas do Governo de Lula da Silva. Brasília, publicação do Grupo de Trabalho de Política Educação, 2004 apud GARLET, M; GUIMARÃES, G; BELLINI, M. I. B. Cotas para estudantes indígenas: inclusão universitária ou exclusão escolar? Revista de Educação. Porto alegre. v. 33. n. 1. 2010. http://revistaseletronicas.pucrs.br/ojs/index.php/faced/article/view/5208. Acesso em: 5. FEV. 2016.

105. VIEIRA, P.A. As especificidades da mercadoria força de trabalho: Marx revisitado. Acta scientiarum - human and social sciences. Maringá. V. 34. n. 2. 2012. Disponível em: http://periodicos.uem.br/ojs/index.php/ActaSciHumanSocSci/article/view/18632. Acesso em: 15. MAI. 2016. 


\section{APÊNDICES}

APÊNDICE A - FLUXOGRAMA ORIENTADOR DE BUSCA EM SÍTIO ELETRÔNICO - PLATAFORMA FORÇA DE TRABALHO EM SAÚDE

APÊNDICE B - DESCRIÇÃO DO FLUXOGRAMA ORIENTADOR DE BUSCA EM SÍTIO ELETRÔNICO - PLATAFORMA FORÇA DE TRABALHO EM SAÚDE

APÊNDICE C - MATRIZ DE SISTEMATIZAÇÃO DA FORÇA DE TRABALHO EM SAÚDE NO BRASIL

APÊNDICE D - MATRIZ DE SISTEMATIZAÇÃO DA FORÇA DE TRABALHO INDÍGENA EM SAÚDE POR REGIÃO E ESTADO

APÊNDICE E - MATRIZ DE SISTEMATIZAÇÃO DOS DADOS DE SAÚDE INDÍGENA - SESAI/IMIP/SPDM/CAIUÁ - ATENÇÃO À SAÚDE

APÊNDICE F - FLUXOGRAMA ORIENTADOR DE BUSCA EM SÍTIO ELETRÔNICO - INSTITUTO DE PESQUISA ANÍSIO TEIXEIRA (INEP)

APÊNDICE G - DESCRIÇÃO DO FLUXOGRAMA ORIENTADOR DE BUSCA EM SÍTIO ELETRÔNICO - INSTITUTO DE PESQUISA ANÍSIO TEIXEIRA (INEP) 


\section{APÊNDICE A - FLUXOGRAMA ORIENTADOR DE BUSCA EM SÍTIO ELETRÔNICO - PLATAFORMA FORÇA DE TRABALHO EM SAÚDE}

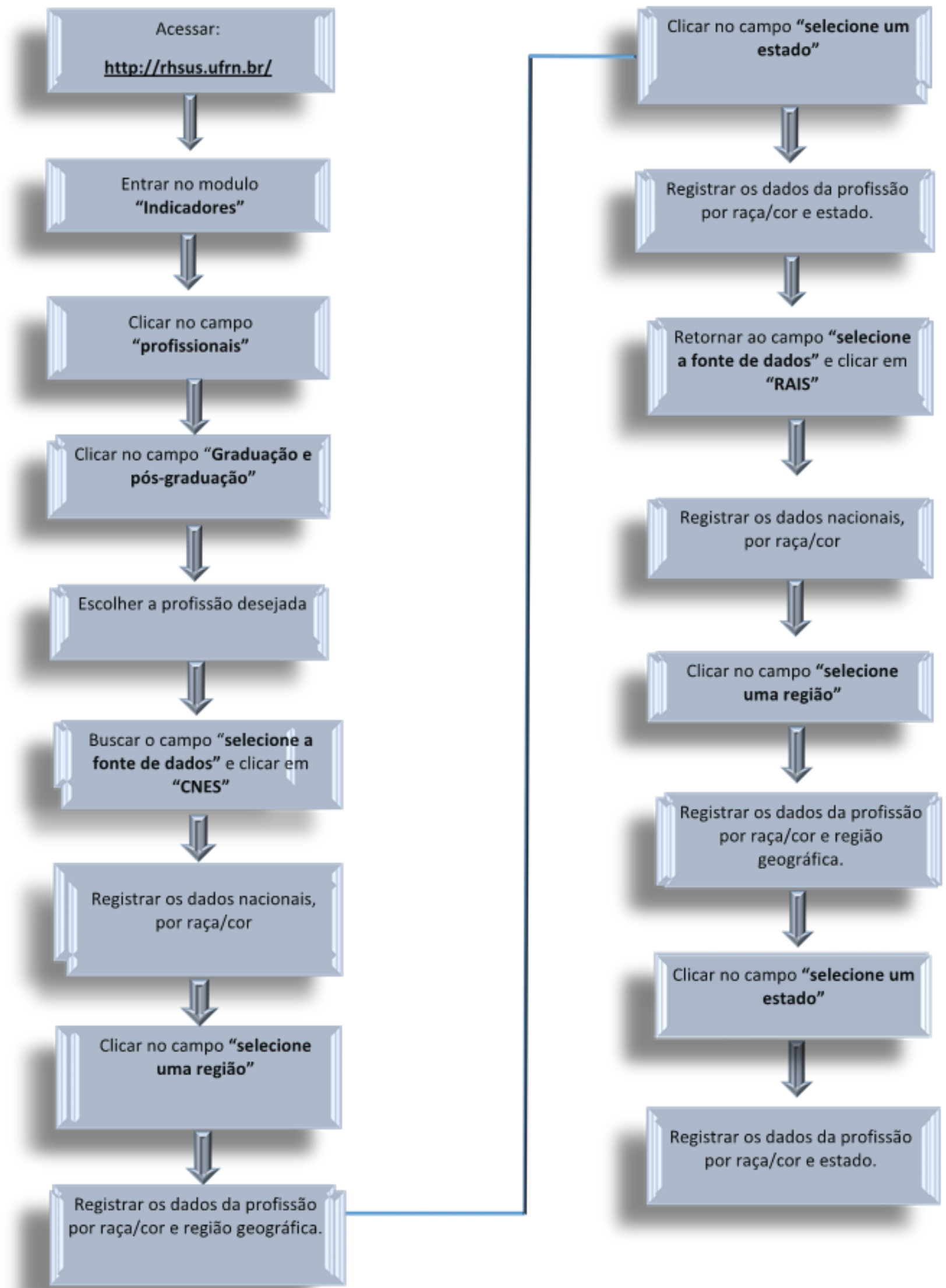




\section{APÊNDICE B - DESCRIÇÃO DO FLUXOGRAMA ORIENTADOR DE BUSCA EM SÍTIO ELETRÔNICO - PFTS}

1. Acessar o endereço eletrônico: http://rhsus.ufrn.br/

2. Entrar no módulo "Indicadores", que permite levantar dados relativos ao perfil, características dos empregos e das unidades pelas quais se distribuem profissionais e demais trabalhadores inseridos na atenção à saúde no País, nas regiões, estados, Distrito Federal e municípios brasileiros. Bem como informações sobre a formação especializada do profissional médico, mostrando carências e convergências destes profissionais em toda região brasileira bem como a distribuição das vagas dos programas de residência médica pelo País.

3. Clicar no campo "profissionais", que permite o acesso aos três níveis de escolarização que auxilia na caracterização do profissional atuante na assistência à saúde (superior, técnico e elementar).

4. Clicar no campo "Graduação e pós-graduação", que permite o acesso a informações extraídas do CNES a respeito das 14 profissões de saúde, de acordo com indicação contida na Resolução № 287 (08/10/1998) do Conselho Nacional de Saúde. A busca pode ser realizada considerando a distribuição etária, raça/cor, localização geográfica e demográfica.

5. Clicar na profissão de saúde desejada, uma por vez, considerando as seguintes alternativas: "Assistentes sociais", "Biólogos", "Biomédicos", "Enfermeiros", "Farmacêuticos", "Fisioterapeutas", "Fonoaudiólogos", "Médicos", "Médicos veterinários", "Nutricionistas", "Odontólogos", "Profissionais de Educação Física", "Psicólogos" e "Terapeutas ocupacionais".

6. Buscar o campo "selecione a fonte de dados" e clicar em "CNES - Cadastro Nacional de Estabelecimentos de Saúde". Esta opção permite o acesso aos dados dos profissionais da assistência à saúde cadastrados no CNES.

7. Registrar os dados nacionais, por raça/cor, em matriz específica: profissão, fonte de dados, total de profissionais no Brasil, número absoluto de profissionais por raça/cor, o que permitirá o cálculo posterior do percentual de profissionais indígenas na assistência à saúde e o traçado de comparativos necessários.

8. Clicar no campo "selecione uma região" e escolher uma região geográfica por vez, considerando como opções as 5 (cinco) regiões do Brasil: centro-oeste, nordeste, norte, sudeste e sul. Esta seleção permite o acesso aos quantitativos de profissionais atuantes na assistência à saúde da respectiva região e Unidades da Federação que a compõem. 
APÊNDICE C - MATRIZ DE SISTEMATIZAÇÃO DA FORÇA DE TRABALHO EM SAÚDE NO BRASIL

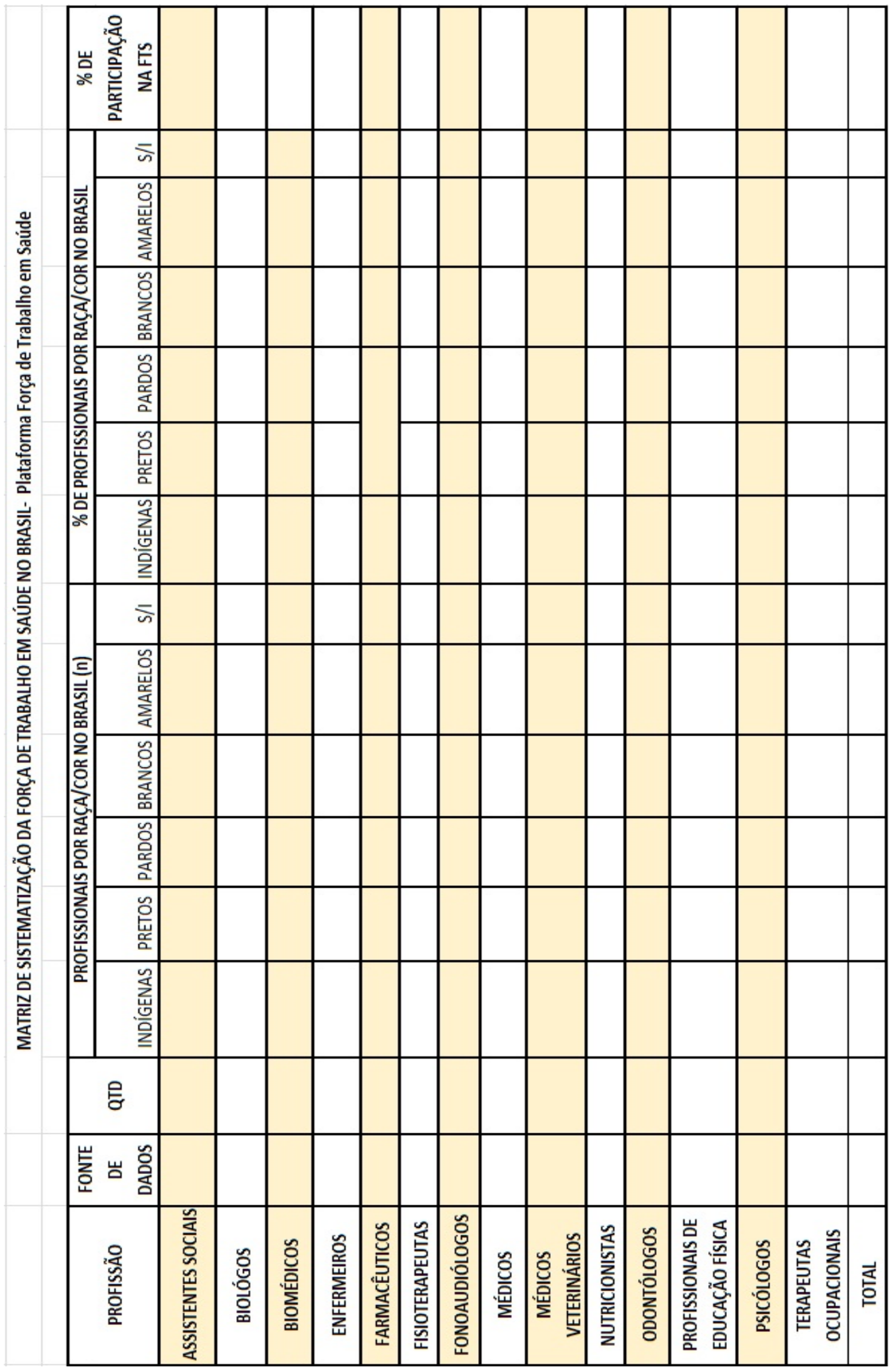


APÊNDICE D - MATRIZ DE SISTEMATIZAÇÃO DA FORÇA DE TRABALHO INDÍGENA EM SAÚDE POR REGIÃO E ESTADO

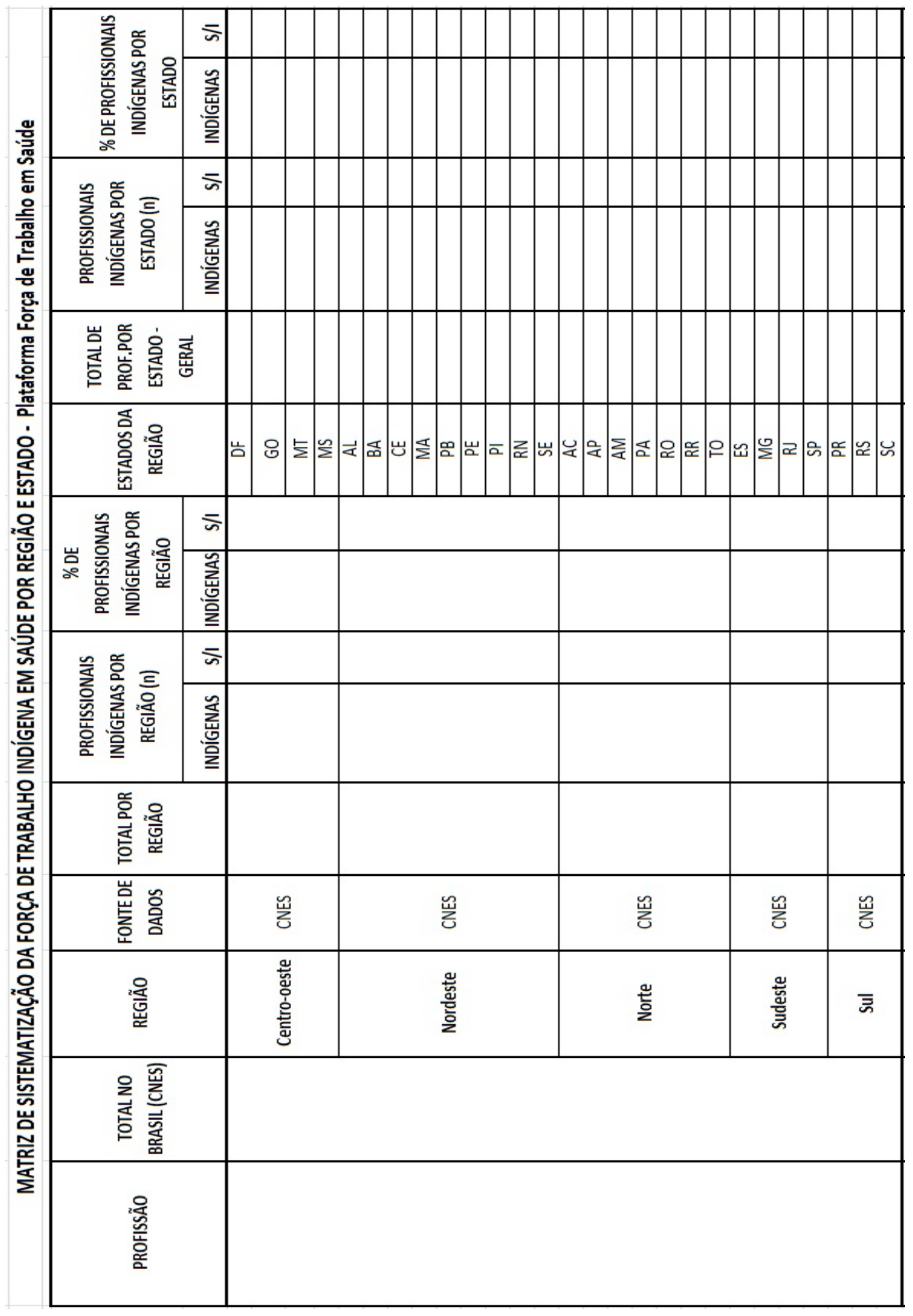




\section{APÊNDICE E - MATRIZ DE SISTEMATIZAÇÃO DOS DADOS DE SAÚDE INDÍGENA - SESAI/IMIP/SPDM/CAIUÁ - ATENÇÃO Á SAÚDE}

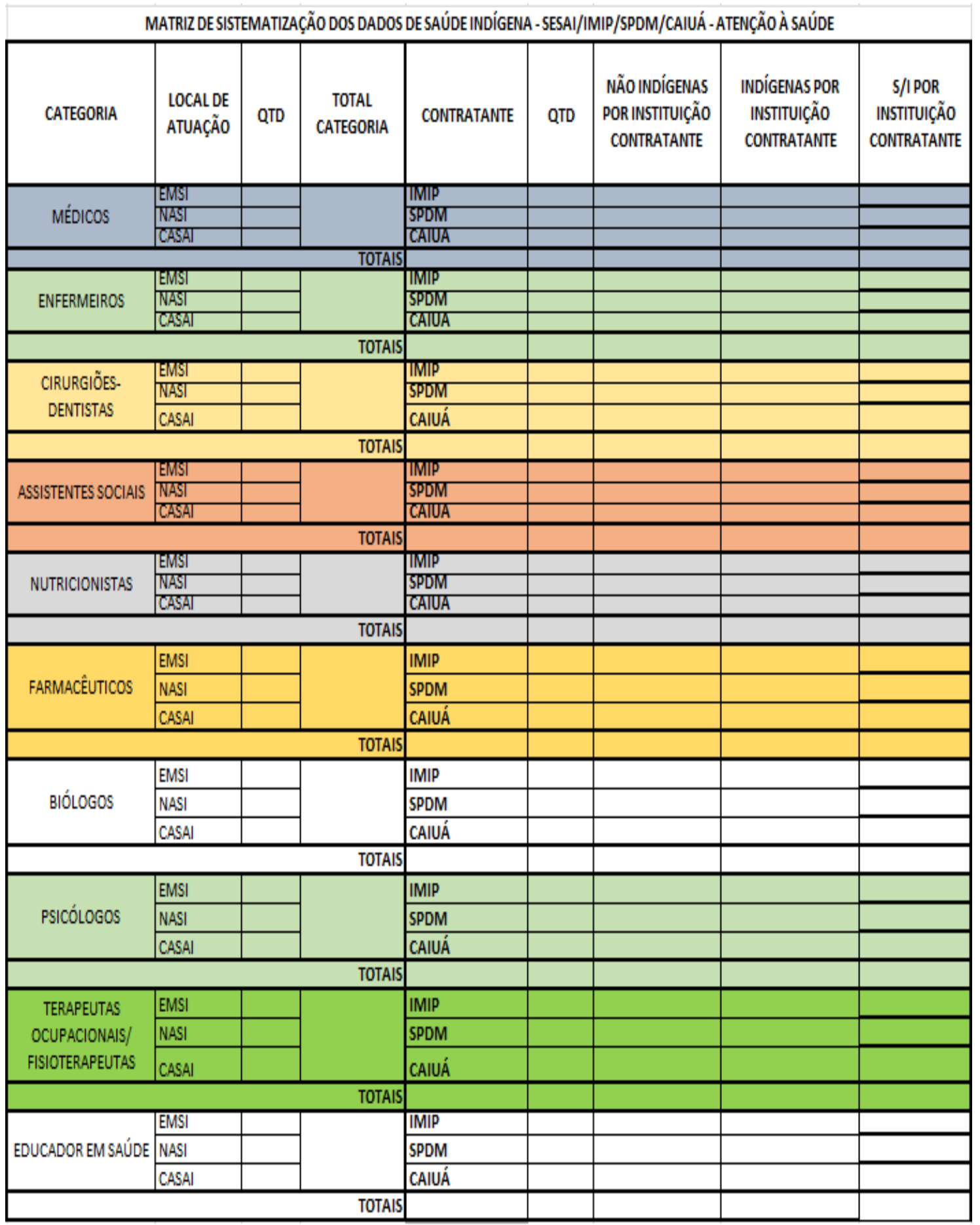

Legenda: EMSI - Equipe Multidisciplinar de Saúde Indígena; NASI - Núcleo de Apoio à Saúde Indígena; CASAI - Casa de Apoio à Saúde Indígena. 
APÊNDICE $F$ - FLUXOGRAMA ORIENTADOR DE BUSCA EM SÍTIO ELETRÔNICO - INSTITUTO DE PESQUISA ANÍSIO TEIXEIRA (INEP)

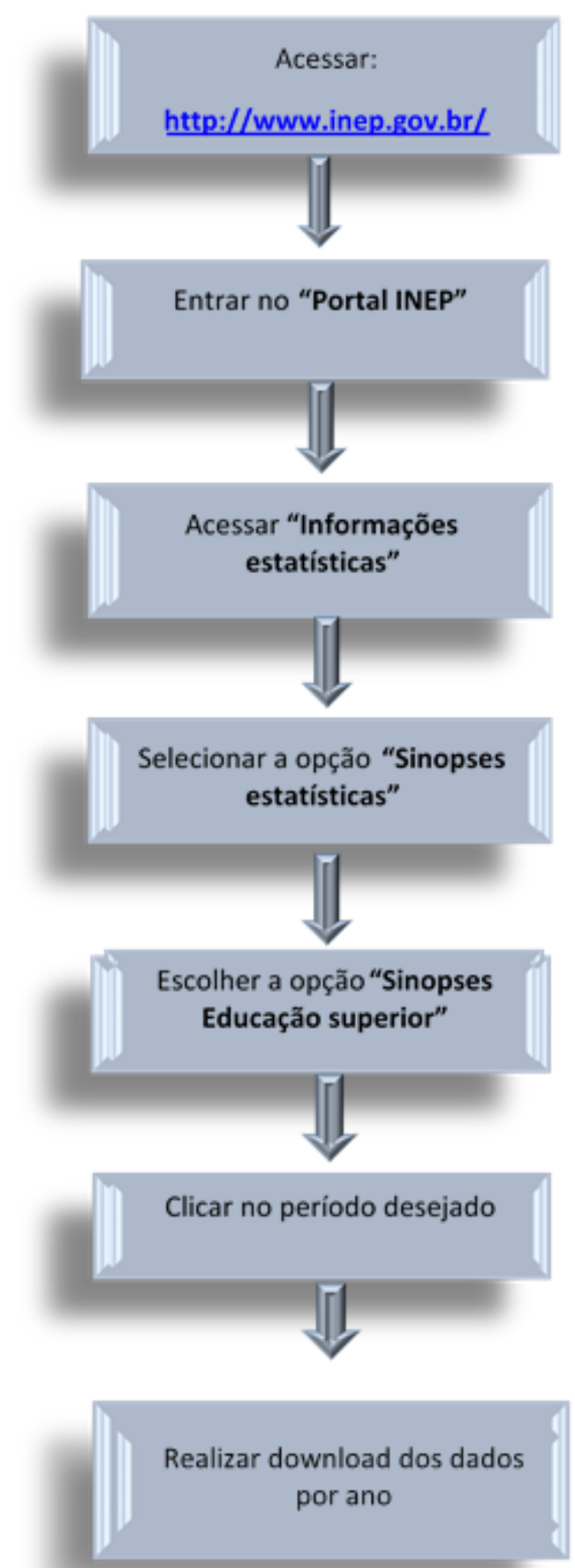




\section{APÊNDICE G - DESCRIÇÃO DO FLUXOGRAMA ORIENTADOR DE BUSCA EM SÍTIO ELETRÔNICO - INSTITUTO DE PESQUISA ANÍSIO TEIXEIRA (INEP)}

1. Acessar o endereço eletrônico: http://www.inep.gov.br/;

2. Entrar no "Portal INEP" - Instituto Nacional de Estudos e Pesquisas Educacionais Anísio Teixeira, que disponibiliza os dados e informações provenientes dos estudos, pesquisas e avaliações sobre o Sistema Educacional Brasileiro, realizados em todos os níveis e modalidades de ensino no território brasileiro, já que se constitui em autarquia vinculada ao Ministério da Educação (MEC).

3. Acessar "Informações estatísticas" no lado esquerdo da página, que permite acesso aos dados provenientes dos levantamentos estatísticos e avaliativos realizados pelo INEP.

4. Selecionar a opção "Sinopses estatísticas", que permite o acesso às sínteses dos levantamentos estatísticos e avaliativos realizados na educação básica e superior.

5. Escolher a opção "Sinopses Educação superior" no canto esquerdo da página para ter acesso aos dados organizados por ano.

6. Clicar no período desejado;

7. Realizar o download do respectivo arquivo de dados. 
ANEXOS

ANEXO A - PARECER FINAL DA COMISSÃO NACIONAL DE ÉTICA EM PESQUISA

ANEXO B - PARECER DE SUBMISSÃO DE ARTIGO NA REVISTA SAÚDE E SOCIEDADE 


\section{ANEXO A - PARECER FINAL DA COMISSÃO NACIONAL DE ÉTICA EM PESQUISA}

\section{COMISSÃO NACIONAL DE ÉTICA EM PESQUISA}

\section{PARECER CONSUBSTANCIADO DA CONEP}

\section{DADOS DO PROJETO DE PESQUISA}

Thtulo da Pesqulsa: A PRESENÇA DO INDIGENA NA ASSISTÉNCIA A SAŨDE NO ERASIL Pesqulaador: JULI OLIVEIRA

Area Tematica: Estudos com populaçles indigenas;

Versas: 2

CAAE: 60327716.6 .0000 .0030

Institulçaso Proponente: FACULDADE DE SAUDE - FS

Patrocinador Principal: Finandamento Proprio

DADOS DO PARECER

Número do Parecer: 1.878 .750

Apresentaça do Projeto: Introduçăa:

A força de trabalno (FT), como concelto fundamentado no pensamento de Kal Marx, remete ao potenclal para o trabaho que o indlviduo vende ao capitallsta para ser utllizado na produçăo. Sendo assim, a FT de um homem se relaciona a sua indlvidualdade: seu uso esta Imitado as energlas ativas e a força fislca do trabalhador, e seu valor e defnido pela quantidade de trabalno necessaria a produçâo. $O$ autor diz alnda que, Na base do sistema de salarios, o valor da força de trabalno e estabelecldo como o de outra mercadoria e, como diferentes especles de força de trabaho tem diferentes valores ou requerem diferentes quantidades de trabalho para a sua produçalo, tem de alcançar diferentes preços no mercado de trabalho. Roberto Nogueira acrescenta ao concelto supractlado o de recursos humanos ( $\mathrm{RH})$, apontando diferenças entre FT e RH. Originaimente se distinguem por ser o primeiro oriundo da econom/a poltica (Marx) e o ultimo, da administraçăo e da teorla dos sistemas. Enquanto a teorla marxista destaca o processo de trabalho, tradurzindo a relaçăo entre as pessoas, a teorla dos sistemas abstral as relaçbes soclals e nâo desenvolve a concepç5o do trabalho humano, mas a noça do trabalhador como insumo necessario a produçăo. No campo da saude, cabe destacar a apllcabllidade destes conceltos e as especincadades que tornam este campo complexo no que se refere a força de trabalho em saude (FTS). Pereira, utllizando 0 concelto proposto por Palm aponta que: [com] a compreensalo dos

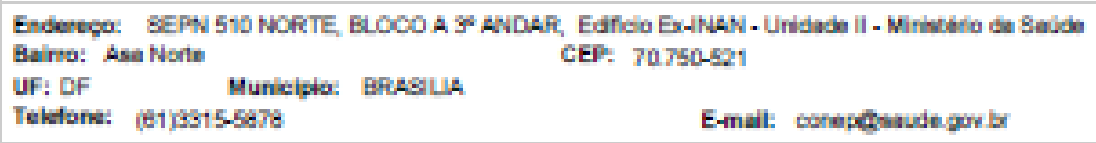




\section{COMISSÃO NACIONAL DE ÉTICA EM PESQUISA}

Conthuacks do Paracer: 1 ana.7so

Recursos Humanos como Força de Trabalho na sua dupla dlmensafo - 'mercadorla' especinca e ator social capaz de fazer historia - alem de 'sujelto-agente' das praticas de saude, eticamente comprometido com a vida e com a reduçấ do sotrimento humano, Implica a superaçato da ldela de meros insumos da funçăo de produçăo. Ja năo bastam $\propto s$ enfoques da administraçăo, do planejamento nomativo, de teorla do capital humano. Nesse contexto, as attuidades de assistencla a salude integram o conjunto dos chamados serviços de consumo coletivo, os quals, por conta das mudanças na estrutura global da socledade, fazem dos serviços de saude - principalmente das mercadorias que săo produzidas e velculadas por eles - um dos Itens mals importantes empregados na manutençăo e ampllaçăo da escala de produçăo capitallsta. A compreensto das partcularidades do trabaho em saude e citada por Noguelra como relevante na avalaç50 da FTS. Săo exemplos: o acentuado dinamismo tecnologico, as inovaçßోes tecnologicas, a introduçăo de novos serviços, a açăo combinada entre varios profislsonals e a aplicaçăo das forças produtivas das clenclas e tecnologlas para elevar a produtividade. Sendo assim, conhecer estas e outras especincldades que compðem o trabalho em saude e fundamental para a gestăo eficlente do trabalho e para o enfrentamento da crise da FTS. Multo tem se falado sobre a crise global da FTS, que se caracteriza por dencit global de mals de 4 milhøes de pronssionals de saude, alem de desigualdades no que se refere a distribulç5̆o e ao acesso a FTS. O Brasil năo foge a regra, apresentando deficit quantitativo e qualtativo de pessoal, principaimente em regiðes rurals e periferlas urbanas ou de dificll acesso. Vislumbra-se 0 agravamento desta crise nos proximos anos, pols a demanda por proflssionals de saude cresce marcadamente, acompanhando as mudanças epideniologicas e sociodemogra"cas. Associado e compondo a crise da FTS, ha ainda as Iniquidades entre mulheres e homens, Indigenas, negros, brancos, e amarelos, - que gera acentuada assimetrla no mercado de trabalho em saude no Brasll. Lals Abramo reforça a desigualdade de genero e raça como elxo estruturante da matriz da desigualdade social no Brasll,

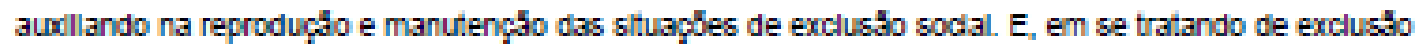
social e mercado de trabalho, toma-se pertinente analsar a situaçăo dos Indigenas braslleiros, que pouco aparecem nas estatisticas dos trabalhadores em saude e multo menos nos referenclals tecricos que abordam as desigualdades de genero e raça no trabalho. E curioso como dlversos estudlosos pautam as desigualdades de raça no trabaho, restringindo as analses aos brancos e negros - Indicando diferencials no quantitativo de brancos e negros no mercado de trabalho, de remuneraçá, de jomada de trabalho, de

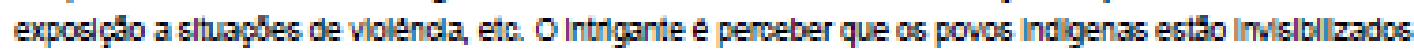
na memoria dos pesqulsadores dessa tematica. Sera que náo temos Indigenas Inseridos no mercado de trabalho no Brasil? Ou sera

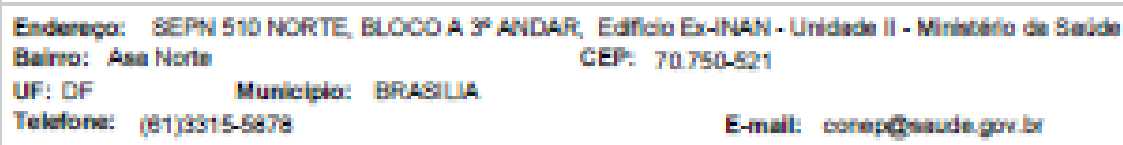




\section{COMISSÃO NACIONAL DE ÉTICA EM PESQUISA}

Continuacks do Paracer: 1.070 .750

que a Invisibilldade ja se constitue no preconcelto e racismo empregados contra 06 povos indigenas? Segundo Lima "ainda falta multo para que os braslielros descubram que nâo amam e nem admiram os nossos ancestrals Indlgenas, muto menos sentem-se descendentes destes povos". No Imaginario popular os Indigenas săo associados a ldela de viverem nus, dançando no melo da fioresta, enfeltados com penas, o que gera uma noçấ equlvocada e dlferentes reaçbes que vå desde uma simpatla ate violenclas dlversas. Vale ressatiar, que multas vezes a simpatia e tâo perigosa quanto a agressăo aberta empregada contra os indigenas. Por essa otica, a simpatia (reproduzida pela Infantillzaçăo do Indigena) subestima, discrimina e inferioriza tanto quanto a agressło aberta o faz. Considerando a diversidade das populaçbes Indigenas do Brasil - que hoje somam 896,9 ml pesso36, em 243 etri 36 , falando 180 Inguas diferentes - e sua distribulçăo geografica no pais - $324.677 \mathrm{mll}$ em area urbana e $572.222 \mathrm{ml}$ em area rural -, faz-se necessario pensar em pollticas publicas que respondam a essa conformaçăo social, representada pela ocupaçăo crescente dos centros urtanos pelos povos indigenas e pela persistencia da situaç̧̊ de exclusăo soclal e ausencla de direttos basicos. Segundo Lals Abramo, a anallse das desigualdades de genero e raça deve ser conslderada nos processos de formulaçăo de poilticas publicas em geral. Um exemplo săo as politicas de açbes afimativas, que se caracterizam como um conjunto de medidas planejadas para promover o avanço de determinados grupos raclals, etnicos e socloeconomicos historicamente destavorecidos. Por melo da Impulsăo a mobilldade social, ta's politcas sấo uma forma de compensaçăo năo so por conta de discriminaçấo sotilda no passado, mas tambem como reparaçăo de discriminaçbes que ocorrem no presente. Nesse contexto, vale destacar a participaçâo da poi itica de açbes afrmativas para 06 povos Indigenas, que começa a ganhar centralldade nos debates na area da Educaçâo. Porem, mutos entraves se encontram enralzados nas 'sequelas' debxadas pelo processo de invasăo e colonizaçăo do Brasl, como e o caso da Idela assimllacionista clada por Uma , segundo a qual os Indlgenas sâo apenas "uma categoria transitoria, pols uma vez expostos a clvilizaçäo, delxarlam de se-10". Alnda segundo Lima, existe uma crescente demanda dos povos Indigenas por formaçăo no Ensino Superior (ES), que envolve a preparaçăo destes en direçăo a novos relacionamentos com o estado braslleiro e com as redes locals, dispensando medladores năo indigenas, a partir do cruzamento de conhedmentos tradlcionals indigenas e de saberes ocidentals. Mas, como o proprio autor destaca, e imperativo que sejam reallzados estudos sobre o acesso e a demanda dos indlgenas pelo ES, em ambito naclonal, Ja que as estatisticas braslleiras sobre estes povos ainda săo inciplentes, quando năo inexistentes. Sendo assim, toma-se de extrenna relevancla relacionar a presença dos indigenas no ensino superior e as poiticas de açbes aftrmativas com o panorama da FTS e seus

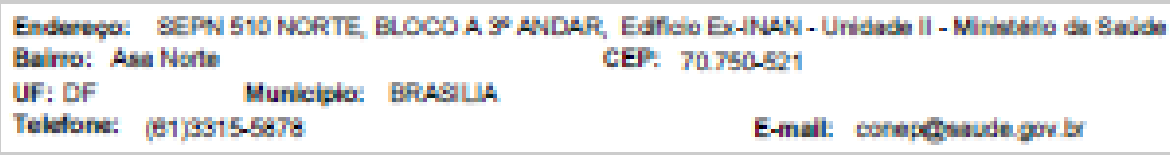




\section{COMISSÄO NACIONAL DE ÉTICA EM PESQUISA

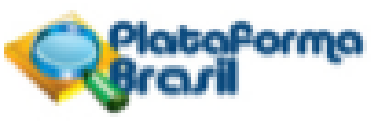

Conthuagla do Paracer 1.070 .750

desdobramentos no mercado de trabalho em saude. Principalmente porque ha escassez de estudos que abordem a situaçăo dos povos Indlgenas no mercado de trabaho no contexto das poilticas de aç̧es afrmativas na formaçăo e captaçăo dos indlgenas no campo do trabalho em saude. Portanto, o presente estudo se Justifica e ganha destaque no campo das politicas, programas e açles de gestafo do trabaho em saude no Brasll, considerando:

- a ausencla de estudos que tracem o panorama da torça de trabalho indigena no campo da saude;

- a necessidade de produçăo de dados sobre as populaçbes indigenas no Brasil; $e$,

- a necessidade de realzar a gestâo do trabalho dos Indigenas que estăo no mercado de trabalno (foco no combate ao racismo, a discrimaçăo, na

saude do trabalhador e da trabahadora indigena e na preservaçăo da diversidade cultural).

Hipotese:

1 - Existencla de indlgenas atuando na assistencla a saúde no Brasil.

\section{Metodologla:}

Trata-se de una pesquisa descritiva exploratorla, ja que se propole a descrever as caracteristicas dos trabahnadores Indigenas que atuam na assistencla a saude no Brasil. E alnda de natureza aplicada, ja que objetiva a geraçăo de conhecimento de apllcaça pratca, voltada para o enfrentamento de desigualdades de oportunidades para os indigenas braslleiros no mercado de trabalho, especitcamente no setor saude. A abordagem da pesqulsa e quantitativa e qualtatlva, de anallse documental. A abordagem mlsta fol escollida, considerando a complementaridade destas apontada por Cecila Minayo, o que evidenda a falsa dlcotomla entre a pesquisa qualtativa e quanttativa. A autora aponta que as duas abordagens possuem especincldades e IImites, sendo ambas necessarlas, porem insunclentes para abarcar toda a realldade, quando utllizadas Isoladamente. Afrma alnda que nâo existe abordagem mals clentilica que a outra e que a relaçăo entre a objetividade e a subjetividade năo pode ser pensada como oposiçăto contradtorla. A populaçăo do estudo stao os indlgenas que atuam na assistencla a saúde no Brasll e que estăo registrados no Cadastro Nacional de Estabelecimentos de Saude (CNES), banco de dados de origem publica, sendo considerado documento publico e sistema de informaçăo oficial de cadastramento de informaçbes de todos os estabelecimentos de saude do Brasll, de acordo com a Portaria 1.646, de 2 de outubro de 2015, do Ministerio da Saude. Os dados provenlentes do MS serăo extraldos da Plataforma Força de Trabalho em Saude, tendo os dados originarios do CNES. Vale ressaltar que a Plataforma Força de Trabaho em Saude, tambem e de origem pobllca, de acesso llberado a todo e

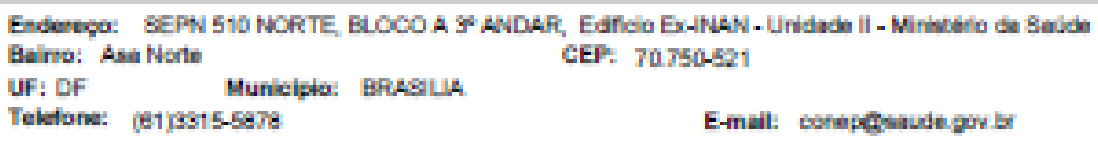




\section{COMISSÃO NACIONAL DE ÉTICA EM PESQUISA}

Continuabla do Paracar: 1.070 .75

qualquer sltuaçấ que possua interesse nos dados que a mesma oferta Trata-se de dados quantitativos sobre os profssionals que atuam na assistencla a saude no Brasl, desagregados por profissalo, reglato geogranca e raçalcor, que necessitarăo de discussfo baseada no contexto historico e soclal da populaçăo Indlgena no Brasll, pemitlndo o dlalogo da abordagem quantitiativa com a quallititva, e consequentemente 0 mehor entendimento da realdade. A coleta de dados referente a força de trabalho indigena sera orientada por 3 (tres) instrumentos de coleta de dados, construldo pela pesquisadora. O primeiro instrumento e o nuxograma orlentador de busca em sittlo eletronico - Platatorma da Força de Trabalho em Saude, composto por todos $\propto 6$ passos necessarios para coletar 05 dados sobre 05 trabalhadores (as) Indlgenas na assistencla a saude, como consta na Matiz de slstematizaçăo da força de trabalho em saude no Brasll com os campos: profissâo, fonte de dados, total, profissionals por raçalcor no Brasil e \% de profissionals por raçalcor no Brasil; e na Matriz de sistematizaça da força de trabaho Indlgena em saude por regla e estado contendo os seguintes campos: profissåo, reglăo, fonte de dados, total por reglăo, total por estado, profissionals Indigenas por regläo, \% de profisslonals indigenas por regåo, pronsslonals indlgenas por estado e \% de profissionals indlgenas por estado.O processo de revisåo de literatura sera orlentado por 1 (Um) Instrumento, a matriz de sistematizaçăo da revisło da ilterahura, composto pelos campos: descrittor unilizado, nùmero do artigo, ttulo, Informaçbes da publicaç̧̆o e link da publicaç5̆o. A busca na literatura sera ortentada buscando responder a algumas perguntas norteadoras. Salo elas: 1 - Cual o panorama da força de trabalno Indigena na saude? 2 - As politticas de açă anmattva tem contribuldo para a a inserçăo pronssional dos Indlgenas? 3 - Existem produçbes na llteratura que abordam a geståo do trabaho Indigena?

Destecho Primario:

Identitncaçăo quanttativa dos trabalhadores indigenas na assistencla a saude no Brasll

\section{Objetlvo da Pesquisa: \\ Cojettvo Primario:}

Analsar a presença do Indigena na assistencla a saude no Brasil.

Objetivo Secundario:

-Identificar o quantitativo de protssionals indigenas de nivel superior atuantes na assistencla a saude no Brasil;

-Identflcar a oferta de vagas exclusivas para indigenas e o nümero de egressos indigenas em

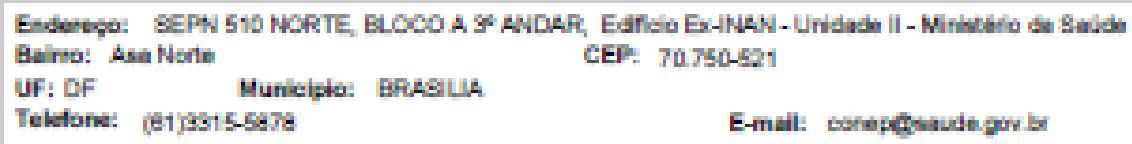




\section{COMISSÃO NACIONAL DE ÉTICA EM PESQUISA}

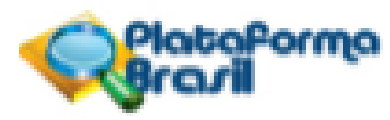

Conthagks do Parecer: 1.070 .750

qualquer sltuaçăo que possua interesse nos dados que a mesma oferta Trata-se de dados quantitativos sobre os profissionals que atuam na assistencla a saude no Brasl, desagregados por profissăo, reglăo

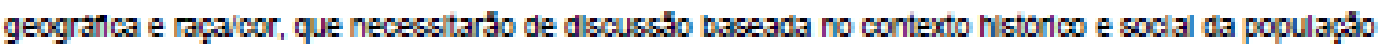
Indigena no Brasil, pemittndo o dlalogo da abordagem quantitativa com a qualitattva, e consequentemente 0 mehor entendimento da realdade. A coleta de dados referente a força de trabalho indigena sera orientada por 3 (tres) instrumentos de coleta de dados, construldo pela pesquisadora. O primeiro instrumento e 0 nuxograma orientador de busca em sitio eletronico - Platatorma da Força de Trabalho em Saude, composto por todos $\propto s$ passos necessarios para coletar $0 s$ dados sobre $0 s$ trabalhadores (as) Indigenas na assistencla a saude, como consta na Matriz de slstennatizaç5̆o da força de trabalho em saude no Brasll com os campos: profissăo, fonte de dados, total, profissionals por raçalcor no Brasll e \% de proflssionals por raça/cor no Brasil; e na Matriz de sistematizaçăo da força de trabalho Indigena em saude por regláo e estado contendo os seguintes campos: pronissalo, regläo, fonte de dados, total por reglöo, total por estado, profissionals Indlgenas por reglâ, \% de profissionals Indigenas por reglăo, pronssionals indigenas por estado e \% de proflssionals indigenas por estado.O processo de revisăo de literatura sera orlentado por 1 (um) Instrumento, a matriz de sistematizaçấ da revisfo da literatura, composto pelos campos: descritor unilizado, nùmero do artigo, ttulo, Informaçbes da publicaçక̆o e link da publicaç5̆o. A busca na literatura sera ortentada buscando responder a algumas perguntas norteadoras. Sto elas: 1 - Qual o panorama da força de trabalho Indigena na saude? 2 - As politicas de açăo aflmattva tem contribuido para a a inserçăo profissional dos Indigenas? 3 - Existem produçbes na llteratura que abordam a geståo do trabaho indigena?

Destecho Primario:

Identificaç5o quantiativa dos trabalhadores Indigenas na assistencla a saude no Brasll

\section{Objettvo da Pesqulsa: \\ Oojettvo Primario:}

Analsar a presença do indigena na assistencla a saude no Brasll.

Oojettivo Secundario:

-Identiflcar o quantitativo de protssionals Indigenas de nivel superior atuantes na assistencla a saude no Brasil;

- Identficar a oferta de vagas exclusivas para indigenas e o numero de egressos indigenas em

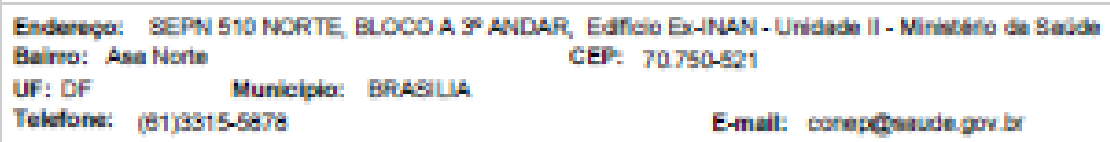




\section{COMISSÃO NACIONAL DE ÉTICA EM PESQUISA}

Continuacks do Paracer: 1.070 .750

II da Resoluçăo CNS 510/16: pesquisa que ưtllze informaçbes de acesso publlco, nos termos da lel $n^{\circ}$ 12.527 , de 18 de novembro de 2011.

A populaçắ do estudo såం os indigenas que atuam na assistencla a saùde no Brasll e que eståı registrados no cadastro nacional de estabelecimentos de saude (cnes), banco de dados de origem publca, sendo considerado documento publico e sistema de informaçăo onclal de cadastramento de informaçbes de todos 06 estabeledmentos de saude do Brasil, de acordo com a portaria 1.646, de 2 de outubro de 2015, do Ministerio da Saude.

Consideraçes sobre os Termos de apresentaçao obrigatorla:

Vide ltem "Conciusbes ou Pendencias e Lista de Inadequaçles".

Conclusoes ou Pendênclas $\theta$ Llsta de inadequaç0es:

Năo foram observados cbices etcos.

Consideraçes Finals a criterio da CONEP:

Dlante do exposto, a Comlssto Nacional de Ética em Pesquisa - Conep, de acordo com as atribulçbles definidas na Resoluçăo CNS $n^{\circ} 466$ de 2012 e na Noma Operacional n 001 de 2013 do CNS, mantiesta-se pela aprovaçăo do projeto de pesquisa proposto.

Shuaçăo: Protocoio aprovado.

Este parecer fol elaborado baseado nos documentos abalxo relaclonados:

\begin{tabular}{|c|c|c|c|c|}
\hline Tipo Documento & Arquvo & Postagem & Autitor & Stuaçao \\
\hline $\begin{array}{l}\text { Informaçes Basicas } \\
\text { do Projeto }\end{array}$ & $\begin{array}{l}\text { PB_INFORMAÇOES_BASICAS_DO_P } \\
\text { ROJETO 722028.po" }\end{array}$ & $\begin{array}{l}18 / 10 / 2016 \\
15: 34: 25\end{array}$ & & Acelto \\
\hline $\begin{array}{l}\text { Projeto Detalhado/ } \\
\text { Brochura } \\
\text { Investlgador }\end{array}$ & $\begin{array}{l}\text { PROJETOdetalinacoPresencadeprofissid } \\
\text { nalisindlgenasnaAssistenclasasudenoEr } \\
\text { asllounubro2016.docx }\end{array}$ & $\begin{array}{l}18 / 10 / 2016 \\
15: 32: 39\end{array}$ & JUL OLIVEIRA & Aceltio \\
\hline Outros & $\begin{array}{l}\text { Cartarespostapareceri767145oundubro } 20 \\
16 . \text { docx }\end{array}$ & $\begin{array}{c}18 / 10 / 2016 \\
15: 31: 04\end{array}$ & JUL OLIVEIRA & Acelto \\
\hline Outros & $\begin{array}{l}\text { PESQUISAIINTITULADAARPRESENCAD } \\
\text { INDIGENANASSISTENCIDOD1.pdf }\end{array}$ & $\begin{array}{l}13 / 0912016 \\
16: 52: 07 \\
\end{array}$ & JULOLIVEIRA & Acelto \\
\hline Declaraçabo de & cartaencaminhprojetoa $\mathrm{CE}$ & $13 / 09 / 2016$ & JUL OLIVEIRA & Acelto \\
\hline
\end{tabular}

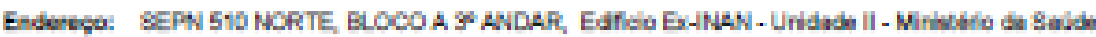
Baino: Asa Norte CEP: $70.750-52$ :

UF: DF Municipia: BResua

Telefone: (e1)ast5-5ere E-mail: corepdsaudegribr 


\section{COMISSÃO NACIONAL DE Platoforma ÉTICA EM PESQUISA}

Conthuacka do Parecer 1.070750

\begin{tabular}{|c|c|c|c|c|}
\hline Pesquisadores & doc & $16: 50: 53$ & JUU CLIVEIRA & Acelto \\
\hline Outros & 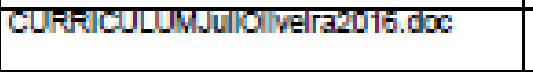 & $\begin{array}{c}30108 / 2016 \\
13.39: 00\end{array}$ & JULOLIVEIRA & Acelto \\
\hline Outros & $\begin{array}{l}\text { CurriculodaOnentadoralMagdaDuartedos } \\
\text { Anlosscherer.port }\end{array}$ & $\begin{array}{c}30 / 08 / 2016 \\
13: 38: 23\end{array}$ & JUU OLIVEIRA & Acelto \\
\hline Outros & TermoConcordDEGERTS2016.doC & $\begin{array}{c}30 / 08 / 2016 \\
13: 36: 16\end{array}$ & JUL OLIVEIRA & Acelto \\
\hline $\begin{array}{l}\text { Declaraçabo de } \\
\text { Pesoulsadores }\end{array}$ & $\begin{array}{l}\text { TermoRespCompromPesqCEPFS2016. } \\
\text { doc }\end{array}$ & $\begin{array}{c}30 / 08 / 2016 \\
13: 35: 05\end{array}$ & JUU OLIVEIRA & Acelto \\
\hline Outros & MocDlspensaTCLECEPFS2016.doc & $\begin{array}{c}30 / 08 / 2016 \\
13: 32: 14\end{array}$ & JUU OLIVEIRA & Acelto \\
\hline $\begin{array}{l}\text { Projeto Detahado / } \\
\text { Brochura } \\
\text { Investlegader }\end{array}$ & 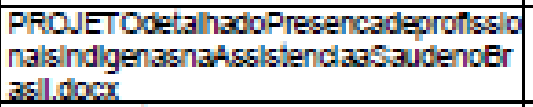 & $\begin{array}{c}24 / 05 / 2016 \\
1404: 58\end{array}$ & JUL OLIVEIRA & Acelto \\
\hline Folha de Rosto & folnaderostocep.pdif & $\begin{array}{c}24 / 05 / 2016 \\
14: 03: 17\end{array}$ & JUU OLIVEIRA & Acelto \\
\hline $\begin{array}{l}\text { TCLE / Termos de } \\
\text { Assentimento / } \\
\text { Justuncativa de } \\
\text { Ausencla }\end{array}$ & CARTAdedispensaTCLE por' & $\begin{array}{c}18 / 05 / 2016 \\
18: 35: 00\end{array}$ & JUU CLIVEIRA & Acelto \\
\hline $\begin{array}{l}\text { Declaraçao de } \\
\text { Pesqulsadores }\end{array}$ & $\begin{array}{l}\text { TERTWODERESPOINSAEILIDADEECON| } \\
\text { PROMISSOC001.pd" }\end{array}$ & $\begin{array}{c}18 / 05 / 2016 \\
18: 34: 29\end{array}$ & JULOLIVEIRA & Acelto \\
\hline $\begin{array}{l}\text { Declaracka de } \\
\text { Institulcato e } \\
\text { Infraestutura }\end{array}$ & TERMODECONCORDANCIADOD1.pU' & $\begin{array}{c}18 / 05 / 2016 \\
18: 34: 18\end{array}$ & JUU CLIVEIRA & Acelto \\
\hline Orçamento & PLANILHADEORCAMENTOO001.pot' & $\begin{array}{c}18 / 05 / 2016 \\
18: 34: 02\end{array}$ & JUU CLIVEIRA & Acelto \\
\hline Brochura Pesquisa & $\begin{array}{l}\text { PROJETOPresencadeprofissionalsindly } \\
\text { enasnaAssistenciaaSaudenoBrasil.docx }\end{array}$ & $\begin{array}{c}18 / 05 / 2016 \\
18: 31: 32\end{array}$ & JUU OLIVEIRA & Acelto \\
\hline
\end{tabular}

situaça do Parecer:

Aprovado

BRASILIA, 22 de Dezembro de 2016

Assinado por:

Jorge Alves de Almelda Venancio

(Coordenador)

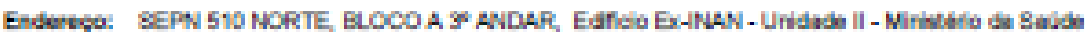

Baino: Asa Nonte

CEF : $70.750-52$.

UF: DF

Municipia: BRASULA

Telefone: (e1)ast5-5e7e

E-mail: corepchaudegribr 
ANEXO B - PARECER DE SUBMISSÃO DE ARTIGO NA REVISTA SAÚDE E SOCIEDADE

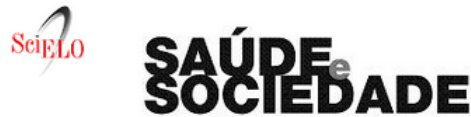

CAPA SOBRE PÁGINADOUSUÁRIO NOTÍCIAS

Capa > Usuário > Autor > Submissões > \#171078 > Avaliação

\#171078 Avaliação

resumo avaliação edição

Submissão

Autores Juli Ferreira de Oliveira

Título CIDADANIA PARA QUEM? ENSAIO DE UMA INDÍGENA SOBRE A CIDADANIA PARA OS POVOS ORIGINÁRIOS DO BRASIL

Seção

Editor Saúde e Sociedade $\square$

Avaliação

Rodada 1

Versão para avaliaçẫ

Iniciado

Última alteração

Decisão Editorial

Decisão

Notificar editor

Versão do editor

Transferir Versão do Autor
171078-828498-2-RV.DOCX 2016-11-2

2017-01-09

2017-01-09
Nenhum(a)

- Comunicação entre editor/autor $Q$ Sem comentários
$171078-833526-1$-ED.DOCX 2016-11-23
Nenhum(a)
Selecionar arquivo. Nenhum arquivo selecionado. Transferir
OPEN JOURNAL SYSTEMS

Ajuda do sistema

USUÁRIO

Logado como
juli_oliveira

: Meus periódicos

- Parfi

AUtor

Submissões

- Ativo (1)

- Nova submissão

IDIOMA

\begin{tabular}{|l|l|}
\hline Selecione o idioma \\
\hline Português (Brasil) Submeter \\
\hline
\end{tabular}

TAMANHO DE FONTE

[Ai] $A$ [A]

NOTIFICAÇÕES

- Visualizar 